\title{
Investigation of the skin microcirculation in lower limb ischaemia
}

Citation for published version (APA):

Beckers, R. C. Y. (1991). Investigation of the skin microcirculation in lower limb ischaemia. [Doctoral Thesis, Maastricht University]. Rijksuniversiteit Limburg. https://doi.org/10.26481/dis.19911004rb

Document status and date:

Published: 01/01/1991

DOI:

10.26481/dis.19911004rb

Document Version:

Publisher's PDF, also known as Version of record

\section{Please check the document version of this publication:}

- A submitted manuscript is the version of the article upon submission and before peer-review. There can be important differences between the submitted version and the official published version of record.

People interested in the research are advised to contact the author for the final version of the publication, or visit the DOI to the publisher's website.

- The final author version and the galley proof are versions of the publication after peer review.

- The final published version features the final layout of the paper including the volume, issue and page numbers.

Link to publication

\footnotetext{
General rights rights.

- You may freely distribute the URL identifying the publication in the public portal. please follow below link for the End User Agreement:

www.umlib.nl/taverne-license

Take down policy

If you believe that this document breaches copyright please contact us at:

repository@maastrichtuniversity.nl

providing details and we will investigate your claim.
}

Copyright and moral rights for the publications made accessible in the public portal are retained by the authors and/or other copyright owners and it is a condition of accessing publications that users recognise and abide by the legal requirements associated with these

- Users may download and print one copy of any publication from the public portal for the purpose of private study or research.

- You may not further distribute the material or use it for any profit-making activity or commercial gain

If the publication is distributed under the terms of Article $25 \mathrm{fa}$ of the Dutch Copyright Act, indicated by the "Taverne" license above, 


\section{INVESTIGATION OF THE SKIN \\ MICROCIRCULATION \\ IN LOWER LIMB ISCHAEMIA}





\title{
INVESTIGATION OF THE SKIN MICROCIRCULATION IN LOWER LIMB ISCHAEMIA
}

PROEFSCHRIFT

\author{
ter verkrijging van de graad van doctor \\ aan de Rijksuniversiteit Limburg te Maastricht, \\ op gezag van de Rector Magnificus, Prof.Mr. M.J. Cohen, \\ volgens het besluit van het College van Dekanen, \\ in het openbaar te verdedigen \\ op vrijdag 4 oktober 1991 om 14.00 uur \\ door
}

Roeland Casper Yvo Beckers 
Promotores:

Prof.Dr. G. Kootstra

Prof.Dr. R.S. Reneman

Co-promotores:

Dr. M.J.H.M. Jacobs

Dr. D.W. Slaaf

\section{Beoordelingscommissie:}

Prof.Dr. B.K. Janevski, voorzitter

Prof.Dr. J.L.H. Evers

Dr. P.J.G. Jörning

Prof.Dr. W.J.B.M. van de Staak

Prof.Dr. F. Sturmans

CIP-DATA KONINKLIJKE BIBLIOTHEEK, DEN HAAG

Beckers, Roeland Casper Yvo

Investigation of the skin microcirculation in lower limb ischaemia / Roeland Casper Yvo Beckers. - Maastricht :

Datawyse. - Ill.

Thesis Maastricht. - With ref. - With summary in Dutch.

ISBN 90-5291-064-2

NUGI 742

Subject heading: lower limb ischemia.

Produktie en lay-out: Datawyse Maastricht, Ruud Leliveld Omslagontwerp: Hanneke de Smet-Mattousch

Druk: Krips Repro Meppel

Het verschijnen van dit proefschrift werd mede mogelijk gemaakt door financiële steun van de Nederlandse Hartstichting, Abbott B.V., Cosmopharma (Byk Nederland B.V.), Duphar Nederland B.V., Medtronic B.V., Organon Nederland B.V., Sanofi B.V. en Schering AG. 
Aan mijn ouders, voor Marion 



\section{CONTENTS}

Chapter 1

GENERAL INTRODUCTION

References

Chapter 2

\section{MA'TERIALS AND METHODS}

2.1 Clinical history and physical examination $\ldots \ldots \ldots \ldots \ldots \ldots \ldots$

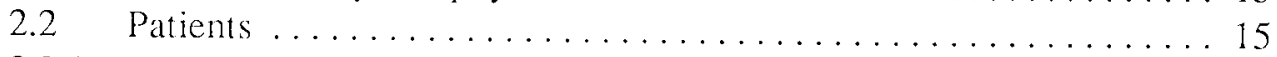

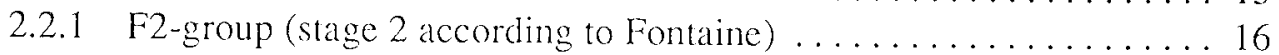

2.2.2 F3/4-group (stages 3 and 4 according to Fontaine) ......... 16

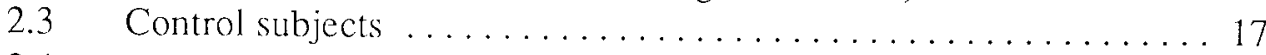

2.4 Data presentation and statistical analysis $\ldots \ldots \ldots \ldots \ldots \ldots \ldots$

2.5 References ............................. 19

Chapter 3

\section{MACROCIRCUIATION}

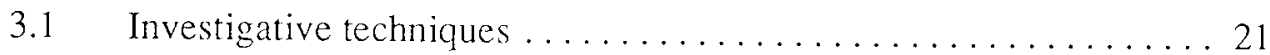

3.1 .1 Arteriography ........................... 21

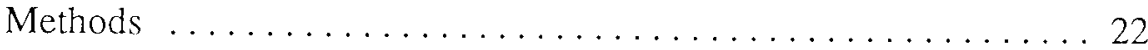

3.1.2 Ankle systolic blood pressure (ASBP) and ankle-to-brachial systolic blood pressure index $(\mathrm{ABI})$ measurements $\ldots \ldots \ldots \ldots \ldots \ldots \ldots$ Methods .......................... 23

3.1.3 Toe systolic blood pressure (TSBP) and toe-to-brachial systolic blood pressure index (TBI) measurements . . . . . . . . . . 24 Methods ........................... 24

3.1.4 Protocol of ankle systolic blood pressure (ASBP), ankle-to-brachial systolic blood pressure index (ABI), toe systolic blood pressure (TSBP) and toe-to-brachial systolic blood pressure index (TBI) measurements 


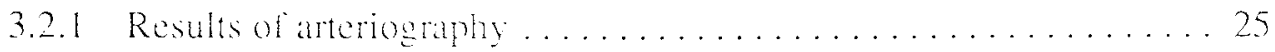

3.2.2 Results of ankle systolic blood pressure (ASBP) and ankle-to-brachial systolic blood pressure index (ABI) measurements in the supine position . . . . . . . . . . . 26

3.2.3 Results of toe systolic blood pressure (TSBP) and toe-to-brachial systolic blood pressure index (TBBI) measurements in the supine and sitting position . . . . . . . 28

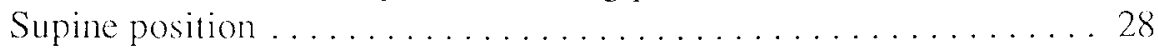

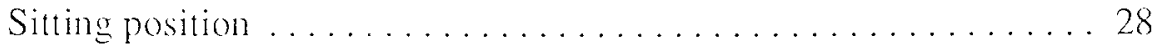

3.2.4 Relation between ankle systolic blood pressure (ASBP), ankle-to-brachial systolic blood pressure index $(\wedge \mathrm{BI})$, toe systolic blood pressure (TSBP), toe-to-brachial systolic blood pressure index (T13I) and arteriography ........ 31

3.3 Discussion . . . . . . . . . . . . . . . . . . . . . 34

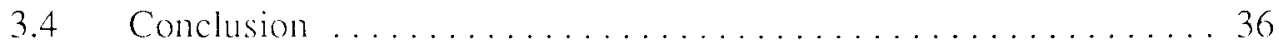

3.5 References ............................. 37

\section{Chapter 4}

4.1 Investigative techniques . . . . . . . . . . . . . . . . . . . 39

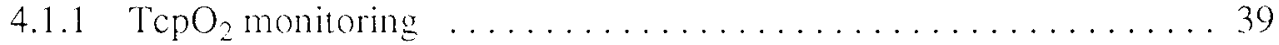

Methods ............................. 40

4.1.2 Intravital skin capillary microscopy $\ldots \ldots \ldots \ldots \ldots \ldots \ldots \ldots 4$

Methods ............................ 42

4.1.3 Protocol of tepO $\mathrm{O}_{2}$ monitoring and intravital skin capillary microscopy ............................ 43

Protocol of $\mathrm{tcpO}_{2}$ monitoring $\ldots \ldots \ldots \ldots \ldots \ldots \ldots \ldots \ldots \ldots \ldots$

Protocol of intravital skin capillary microscopy ........... 43

4.2 Results .............................. . . 47

4.2.1 Results of tcpO $\mathrm{O}_{2}$ monitoring in the supine and sitting position $\ldots 44$

Supine position . ...................... 47

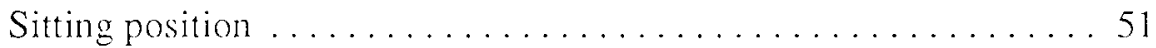

4.2.2 Results of intravital skin capillary microscopy in the sitting position 55

4.3 Discussion . . . . . . . . . . . . . . . . . . . 58

4.4 Conclusion . . . . . . . . . . . . . . . . . . . . . 60

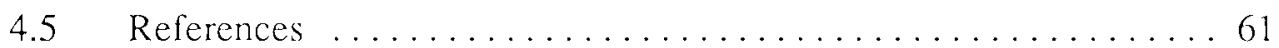


Chapter 5

\section{RELATION BETWEEN TIIE MACROCIRCUIAATION}

5.1 Relation between the skin microcirculation and toe systolic

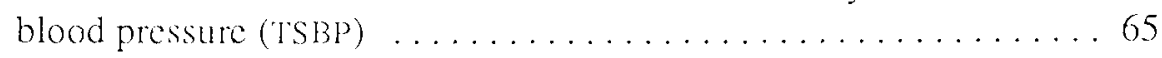

5.2 Relation between the skin microcirculation and ateriography . . . 71

5.3 Conclusion ............................ 73

5.4 References ............................ 74

Chapter 6

GENERAI DISCUSSION

Chapter 7

SUMMARY

Chapter 8

SAMENVATTING

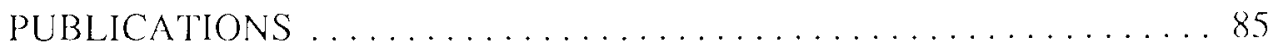

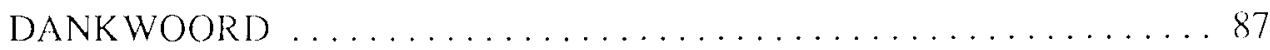

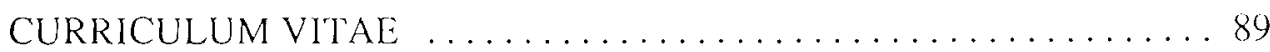





\section{CHAPTER I}

\section{GENERAL INTRODUCTION}

Atheroselerotic arterial obstructive disease of the lower limbs is mainly a disease of the elderly. To classify these patients clinically, the stages according to Fontaine are most commonly used (1). Asymptomatic subjects belong to stage 1 . In symptomatic subjects the range of symptoms varies from moderate peripheral vascular disease, manifested as intermittent claudication (stage 2), to severe peripheral vascular disease (limb threatening ischaemia), manifested as rest pain (stage 3) or ischaemic skin lesions (ulcers and/or necrosis) with or without rest pain (stage 4). To estimate the degree of peripheral vascular disease, techniques like Doppler ultrasound, plethysmography and arteriography are routinely used (2-4). These techniques, however, only provide information about the haemodynamics and anatomy of the macrocirculation. The occurrence of ischaemic skin lesions in some of the patients with severe peripheral vascular disease is indicative of the existence of a compromised skin microcirculation besides an impaired macrocirculation.

The skin microcirculation represents the level at which the exchange between blood and tissue takes place. It is located in the dermis below the epidermis and consists of 2 parts, a nutritional part (Figure 1.1A) and a thermoregulatory part (Figure $1.1 \mathrm{~B}$ ). The combination of the nutritional skin microcirculation and the thermoregulatory skin microcirculation is referred to as total skin microcirculation.

Information about the functional state of the total skin microcirculation can be obtained indirectly by means of transcutaneous oxygen pressure $\left(\mathrm{tcpO}_{2}\right)$ monitoring. Direct non-invasive information about the morphology and haemodynamics of the nutritional skin microcirculation can be gathered with the use of intravital skin capillary microscopy. The relation between the degree of peripheral vascular disease, the extent of macrocirculatory impairments, and the quality of especially the nutritional skin microcirculation is incompletely understood. Ischaemic skin lesions, indicating an insufficient nutritional skin microcirculatory blood flow, do not always develop despite a severely impaired macrocirculatory blood supply. On the other hand ischaemic skin lesions do develop in patients with only limited 


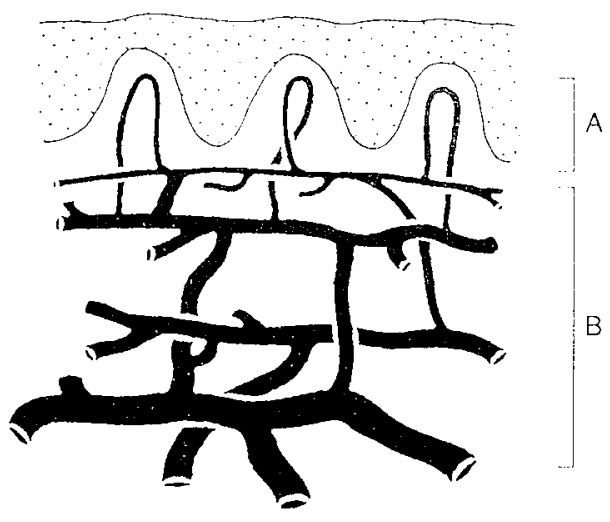

Higure 1.1 Drawing of the skin micrecirculat tion.

A: the nutritional skin microcirculation: capillaries, situated in the papillae of the dermis (papillary dermis), providing the nutrition of the skin.

B: the themoregulatory skin microcirculation: a subpapillary arterial plexus, several subpapillary venous plexuses and arteriovenous anastomoses localized in the reticular dermis. The arteriovenous anastomoses, which directly connect arterioles and venules, are found in apical structures such as fingers, toes, ears, nose and palmar surfaces of hands and feet. The reticular dermis mainly deals with body temperature regulation.

macrocirculatory obstructions. These observations indicate that the cause of ischaemic skin lesions may originate from the macrocirculation and/or the skin microcirculation, emphasizing the need to investigate both levels of the circulation.

Krähenbuhl and Dubas reported that the (macrocirculatory) systolic perfusion pressure in the toe has to decrease below a value of $50 \mathrm{~mm} \mathrm{Hg}$ before total skin blood flow at rest, as indicated by $\mathrm{tcpO}_{2}$ monitoring, may change to subnormal levels (5). Using intravital skin capillary microscopy, Fagrell showed that skin capillaries are devoid of pronounced morphological changes despite marked reductions in systolic perfusion pressure in the toe $(6,7)$. The impaired reactive hyperaemia following the release of a transient arterial occlusion in patients with peripheral vascular disease indicates that in these patients arterioles are dilated at rest $(8-10)$. This autoregulatory response to local ischaemia may be regarded as an attempt to preserve an adequate nutritional skin blood supply.

The aims of the present study were to gain more insight into the relation between the degree of peripheral vascular disease and the condition of the total and nutritional skin microcirculation, and the way in which the skin microcirculation adapts to changes in macrocirculatory blood supply. The following was investigated:

1. the relation between the degree of peripheral vascular disease according to the classification of Fontaine, and objective macrocirculatory parameters, like the systolic perfusion pressure at rest and the anatomic localization of obstructions (chapter 3). 
2. the relation between the degree of peripheral vascular disease according to Fontaine's classification, and objective total and nutritional skin microcirculatory parameters, like skin blood flow at rest and the degree of arteriolar dilation at rest (chapter 4).

3. the relation between total and nut ritional skin microcirculatory parameters, and macrocirculatory parameters (chapter 5).

In this thesis macrocirculatory information was obtained with the use of Doppler ultrasound, plethysmography and arteriography, whereas information about the skin microcirculation was gathered by means of $\mathrm{cpO}_{2}$ monitoring and intravital skin capillary microscopy. A historical review of these macrocirculatory and skin microcirculatory investigative techniques is given in chapters 3 and 4 , respectively. Information about the clinical histories and physical examinations of the subjects, who were investigated in this study, and the way, in which data are presented and statistical analysis is performed, is given in chapter 2. A general discussion concludes this thesis (chapter 6). 


\section{REFERENCS}

1. Fontaine R. Riveaux R, Kim M. Kieny R. Résultats des opénions nyerémiantes (sympathectomies lombaires ef artériectomies) dans les oblierations artérielles chroniques spontanées des membres. Rev Chir 1953:72:264-30.

2. Yao ST. Hacmodynamic studies in peripheral arterial disease. Brit 3 Surg 1970;57:761-6.

3. Ramsay DE, Manke DA, Sumner DS. Toe blood pressure. A valuable adjunct to ankle pressure measurement for assessing peripheral arterial discase.

J Cardiovasc Surg 1983:24:43-8.

4. Neiman HL, Yao JST, eds. Angiography of vascular disease. New York: Churchill Livingstone Inc., 1985.

5. Krähenbühl B, Dubas JM. Transcutaneous oxygen pressure on the foot of normal subjects and patients suffering from arterial occlusive disease. In: Jageneau AHM, ed. Noninvasive methods on cardiovascular haemodynamics. Amsterdam: Elsevier/North-I Iolland Biomedical Press, 1981:469-74.

6. Fagrell B. Vital capillary microscopy. A clinical method for studying changes of the nutritional skin capillaries in legs with arteriosclerosis obliterans. Scand J Clin Lab Invest 1973:31 (suppl 133):1-50.

7. Fagrell B. Vital microscopy. A clinical method for evaluating the risk of skin necrosis in patients with occlusive arterial disease. Bibl Anat 1973;11:328-33.

8. Schwartz RW, Freedman AM, Richardson DR et al. Capillary blood flow: Videodensitometry in the atherosclerotic patient. J Vasc Surg 1984;1:800-8.

9. Bongard $O$, Fagrell $B$. Discrepancies between total and nutritional skin microcirculation in patients with peripheral arterial occlusive disease (PAOD). Vasa 1990;19:105-11.

10. Jacobs MJHM, Beckers RCY, Jörning PJG, Slaaf DW, Reneman RS. Microcirculatory haemodynamics before and after vascular surgery in severe limb ischaemia - the relation to post-operative oedema formation. Eur J Vasc Surg 1990;4:525-9. 


\section{CHAPTER 2}

\section{MATERIALS AND METHODS}

In this chapter the clinical histories and physical examinations of the subjects, who participated in this study, are presented. Furthermore, the way of data presentation and statistical analysis is described. For detailed information about macrocirculatory and skin microcirculatory investigative methods, the reader is referred to chapters 3 and 4 , respectively.

\subsection{CLINICAL HISTORY AND PHYSICAL EXAMINATION}

Prior to the macrocirculatory and microcirculatory investigations, data concerning the clinical backgrounds of all participating subjects were obtained by means of a questionnaire. Detailed information was collected about the nature and duration of the peripheral vascular complaints, smoking habits, and the presence of diabetes, hypertension and other current or previous diseases. An inventory was taken of all prescribed medications.

All subjects underwent a physical examination. The localization of ischaemic skin lesions (ulcers and/or necrosis) on the leg of interest distal to the knee-joint was documented. The total surface area of all ischaemic skin ulcers was determined and expressed in square centimetres $\left(\mathrm{cm}^{2}\right)$. At the end of the examination colour photographs of the ischaemic skin lesions were taken.

\subsection{PATIENTS}

Seventy-seven patients with moderate or severe lower limb ischaemia, referred to the hospital between May 1987 and May 1988 for evaluation of their peripheral vascular state, were investigated in this study after giving their informed consent. The median age of this group was 68 years (range: $39-90$ years). It consisted of 54 men with a median age of 66 years (range: $39-90$ years) and 23 women with a 
median age of 72 years (range: $54-90$ years). All patients were classified according to the stages of Fontaine $(\mathrm{F})$.

The F2-group (stage 2) consisted of 39 patients, who suffered from intermittent claudication (moderate peripheral vascular disease). Patients of this F2-group had a median age of 64 years (range: $44-78$ years).

The F3/4-group (stages 3 and 4) consisted of 38 patients. They suffered from severe peripheral vascular disease, which manifested itself in rest pain as such or in ischaemic skin lesions (ulcers and/or necrosis) with or without rest pain. The median age of these patients was 74 years (range: $39-90$ years). The patients belonging to the stages 3 and 4 were combined, because they all suffered from a severely disturbed peripheral arterial blood supply at rest in contrast to the patients belonging to stage 2 .

Both groups of patients are described in detail below.

\subsubsection{F2-group (stage 2 according to Fontaine)}

The 39 patients consisted of 35 men with a median age of 64 years (range: $44-78$ years) and 4 women also with a median age of 64 years (range: 57-65 years). Since in this study only the most affected leg was included, the right leg was investigated in 25 patients and the left leg in 14 patients. Twenty-four patients smoked regularly. Five patients had maturity-onset diabetes mellitus. In 1 patient the diabetes was controlled by an appropriate diet, whereas the other 4 were treated with oral drugs. Eight patients suffered from hypertension. Three of them were treated with beta-blocking agents. One patient was given a combination of a beta-blocker, a vasodilator and a diuretic. A vasodilating drug combined with a diuretic was prescribed to 2 patients. In the 2 remaining patients the hypertension was controlled by a diuretic drug only. Six patients had a myocardial infarction in their clinical history. One patient had undergone coronary bypass surgery, while another patient had been subjected to percutaneous transluminal coronary angioplasty (PTCA). In 1 patient beta-blockade was used to treat angina pectoris. Previous haemodynamically successful central reconstructive vascular surgery of the leg of interest had been performed in 4 patients at least 14 months before entering the study.

\subsubsection{F3/4-group (stages 3 and 4 according to Fontaine)}

This group of 38 patients consisted of 19 men with a median age of 74 years (range: $39-90$ years) and 19 women also with a median age of 74 years (range: 54-90 years). In 25 patients the right leg and in 13 patients the left leg was examined. Thirteen patients were regular smokers. Twenty-six patients had maturity-onset diabetes. In 1 patient an appropriate diet was sufficient to control the diabetes. Eighteen diabetics were treated with oral drugs, while 4 diabetics had to 
be treated with insulin. In 3 patients the diabetes was managed with a combination of oral drugs and insulin. Thirteen patients had hypertension. Five of these patients were treated with a diuretic, whereas a vasodilating agent was taken by 2 patients. A combination of a vasodilator and a diuretic was prescribed to 2 patients, while 2 other patients were treated with a beta-blocker and a diuretic. A vasodilator combined with a diuretic and a beta-blocker was taken by 2 patients. Thirteen patients had a myocardial infarction in their clinical history. Three patients underwent coronary bypass surgery. In 3 patients a beta-blocking agent was prescribed to prevent angina pectoris. Haemodynamically successful reconstructive vascular surgery of the leg of interest was performed in 10 patients at least 8 months before participating in this study. A peripheral reconstructive vascular procedure was performed in 2 patients. In the remaining 4 patients reconstructive vascular procedures consisted of central reconstructive vascular procedures or a combination of central and peripheral reconstructive vascular surgery. Five patients had an amputation of one or more toes of the leg of interest. A beta-blocking agent to prevent glaucoma was prescribed in 1 patient. Thirtythree patients complained of rest pain with a median duration of 55 days. Thirty-three patients exhibited ischaemic skin lesions (ulcers and/or necrosis) on the leg of interest distal to the knee-joint. Ischaemic skin ulcers were mostly seen on toes and heels. The median total surface area of these ulcers was $2.44 \mathrm{~cm}^{2}$ (range: $0.04-50.34 \mathrm{~cm}^{2}$ ). A combination of rest pain and ischaemic skin lesion(s) existed in 28 patients. To compare the nutritional skin microcirculation in the intact skin and in rims of ischaemic skin lesions, the F3/4-group was subdivided into a F3/4-INTACT-group and a F3/4-LESION-group as far as intravital skin capillary microscopic investigations were concerned. The F3/4-INTACT- group consisted of patients $(n=27)$, of whom an intact part of the skin was investigated, whereas the F3/4-LESION-group consisted of patients $(n=11)$, on whom intravital skin capillary microscopy was performed in the rim of an ischacmic skin lesion.

\subsection{CONTROL SUBJECTS}

The control-group, consisting of 10 healthy subjects, was derived from the local community. They all gave their informed consent. Their median age was 68 years (range: 61-77 years). None of these subjects had cardiovascular complaints before or when entering the study. Six men, median age 68 years (range: 61-73 years), and 4 women, median age 68 years (range: $64-77$ years) were included in this group. None of them had diabetes or hypertension. In 8 subjects the right leg and in 2 subjects the left leg was examined. Three subjects smoked regularly. None of the control subjects was taking medication. 


\subsection{DATA PRESENTATION AND STATISTICAL ANALYSS}

In this thesis the results are presented as median values. The Mann-Whitney U test was used for comparison between groups. Differences were considered to be statistically significant at $p<0.05$. Box plots and scatter plots are used as displays $(1,2)$. As shown in Figure 2.1 , a box plot visualizes the following features of a set of data:

- the median value, represented by the line dividing the box.

- the first and third quartiles, corresponding to the two values below which 25 and $75 \%$ of all values fall, respectively. The first and third quartiles are indicated by the lower and upper edges of the box, respectively.

- the 10 th and 90 th percentiles, which correspond to the two values below which 10 and $90 \%$ of all values fall, respectively. The 10 th and 90 th percentiles are represented by the lower and upper edges of the whiskers, respectively.

- stray value(s), straying out beyond the 10 th and 90 th percentiles. Stray values are indicated by open circles.

- stray value

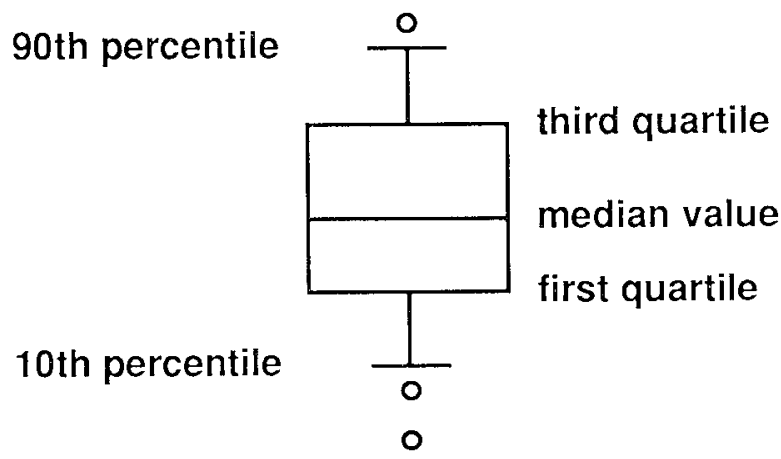

Figure 2.1 Example of a box plot. 


\subsection{REFERENCES}

1. McGill R. Tukey JW, Lamen W. Turations of box plots. The American Statistician 1978:32:12-6.

2. Velleman PF, Hoaglin DC, eds. Applications, basics, and computing of exploratory data analysis. Belmont: Wadsworth inc., 1981:65-92. 



\section{CHAPTER 3}

\section{MACROCIRCULATION}

This chapter deals with the anatomic and haemodynamic investigation of the lower limb macrocirculation by means of arteriography, and ankle and toe systolic blood pressure measurements.

\subsection{INVESTIGATIVE TECHNIQUES}

\subsubsection{Arteriography}

In January 1896, the month after Röntgen announced his discovery of x-rays, Haschek and Lindenthal introduced contrast arteriography by visualizing arteries in an amputated hand after the injection of a viscous radiopaque solution into the brachial artery (1). Brooks was the first to visualize the lower limb arteries by means of an intra-arterial injection of sodium iodide into the superficial femoral artery in 1924 (2). Visualization of the abdominal aorta and its branches was made possible by Dos Santos, Lamas and Pereira-Caldas, who brought the translumbar needle puncture and the translumbar injection of contrast medium into practice (3). The information obtained with contrast arteriography, however, was limited to the region supplied by the punctured artery. Fariñas was the first to report the retrograde passage of a catheter from the femoral artery into the aorta for aortography (4). Seldinger described a modified percutaneous transfemoral catheterization method, which has become the procedure of choice to visualize the arterial system (5). All major arteries are selectively accessible through a single puncture in the femoral or brachial artery by means of this technique. At present, percutaneous transfemoral arteriography according to Seldinger is usually applied to visualize the aorto-iliac and/or lower limb arteries. In addition, intra-arterial and intravenous digital subtraction arteriography (DSA), using photographic image subtraction to separate contrast material densities from those produced by anatomical structures, supplement or are already replacing conventional techniques. 


\section{Methods}

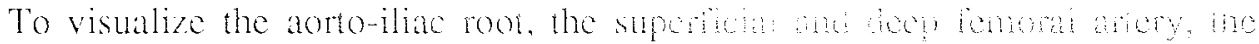
popliteal artery and the arteries below the knee, fratshobu areriography percutaneous transfemoral arteriography according to Seldinger, direct punciure of the femoral artery, intraterial DSA, intravenous DSA or a combination of these techniques was performed on the patients in the supine position. For an extensive description of the arteriographic methods applied, one is referred to textbooks dealing with arteriography $(6,7)$.

To classify the degree of macrocirculatory obstruction the arteriograms (singleplane projections) were reviewed by an experienced vascular surgeon, who was unaware of the outcome of the macrocirculatory and microcirculatory investigations. The leg arteries were subdivided into arteries above and below the knee. The arteries above the knee, which were reviewed separately but classified as a whole, consisted of the aorto-iliac root, and the superficial femoral and popliteal artery. They were classified as patent, if the maximum lumen reduction was $50 \%$ or less, or as obstructed, if somewhere the lumen was narrowed by more than $50 \%$ (8). The arteries below the knee, which comprised the distal popliteal artery and the anterior, posterior and peroneal artery, were classified according to Morton (9). Each of these four arteries was evaluated separately. A complete obstruction yielded a score of 0 . If the lumen was narrowed by more than $75 \%, 50 \%$ or $25 \%$ a score was given of 1,2 or 3 , respectively. A maximum score of 4 was given if no obstruction was seen or if the lumen was narrowed by $25 \%$ or less. Then the sum of these scores was subdivided into 3 different stages of outflow obstruction. Total scores varying between 12-16,7-11 and 0-6 corresponded with Mortonstages 1, 2 and 3 of outflow obstruction, respectively. Combining the classifications of the arteries above and below the knee provided a general arteriographic classification, which comprised 6 ARTERIOGRAPHY-GROUPS representing progressive degrees of macrocirculatory obstruction (Table 3.1).

Table 3.1 Arteriographic classification (6 ARTERIOGRAPHY-GROUPS), representing progressive degrees of macrocirculatory obstruction. This arteriographic classification resulted from combining classifications of arteries above and below the knee.

\begin{tabular}{|l|c|c|c|c|c|c|}
\hline ARTERIOGRAPHY-GROUP & $\mathbf{1}$ & $\mathbf{2}$ & $\mathbf{3}$ & $\mathbf{4}$ & $\mathbf{5}$ & $\mathbf{6}$ \\
\hline Classification of arteries above the knee & pat & obs & pat & obs & pat & obs \\
\hline Morton-stage of outflow obstruction & 1 & 1 & 2 & 2 & 3 & 3 \\
\hline
\end{tabular}

Pat = patent, obs = obstructed; Morton-stage 1 of outflow obstruction = total score of the arteries below the knee ranges between 12 and 16, Morton-stage 2 of outflow obstruction = total score of the arteries below the knee ranges between 7 and 11 , Morton-stage 3 of outflow obstruction $=$ total score of the arteries below the knee ranges between 0 and 6 . 


\subsubsection{Ankle systolic blood pressure (ASBP) and ankle-to-brachial systolic blood pressure index (ABI) measurements}

Since Korotkoff established the sphygmomanometric technique by introducing an auscultatory method in 1905 , blood pressure measurements have routinely been performed in clinical practice (10). For assessment of the influence of arterial obstructions on the perfusion pressure in the lower limb, plethysmographic techniques have been applied to measure the systolic blood pressure at the level of the ankle $(11,12)$. The continuous wave Doppler ultrasound technique to measure blood flow velocity in a non-invasive way was introduced by $\mathrm{Sa}$ tomura and Kaneko (8), and Franklin, Schlegel and Rushmer (13). Clinical experience with this technique indicated, that normal arterial flow produced characteristic sounds and waveforms, which were altered in a recognizable manner by arterial narrowing or occlusion $(14,15)$. Yao reported that the ankleto-brachial systolic blood pressure index (ABI), measured at rest with the use of Doppler ultrasound, separated healthy subjects from patients with moderate or severe peripheral vascular disease (16). Since the ankle-to-brachial systolic blood pressure index does not indicate the relative significance of lesions at various anatomic levels, segmental lower limb pressure measurements may be carried out to resolve this shortcoming (17).

\section{Methods}

When an ultrasonic beam is directed at a blood vessel, emitted ultrasound is backscattered from moving (red) blood cells and its frequency is shifted proportional to the velocity of these (red) blood cells. The following formula shows the quantitative relation between the Doppler frequency shift $(\Delta f)$ on the one hand and the frequency of emitted ultrasound $\left(f_{c}\right)$, the velocity of (red) blood cells $(v)$, and the angle between the ultrasonic beam and the direction of blood flow $(\theta)$ on the other:

$$
\Delta f=\frac{2 \cdot f_{e} \cdot V \cdot \cos \theta}{C}
$$

where $c$ is the velocity of sound in the tissues $(1540 \mathrm{~m} / \mathrm{s}$ for soft tissue). In this study a bi-directional continuous wave Doppler flowmeter with a zero-crossings circuitry to assess the frequency shift was used (Vasculab bi-directional Doppler, model D10, Medasonics). This Doppler flowmeter was connected to a probe, which contained a transducer with two piezo-electrical crystals: one for the continuous emission of ultrasound with a frequency of $8 \mathrm{MHz}$ and one for 


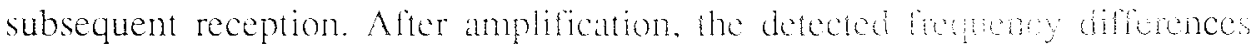
were presented as atudiosignals.

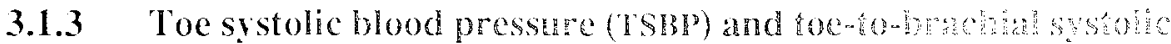 blood pressure index (Til) measurements}

As early as 1934 , Formijne reported toe systolic blood pressure measurenents in patients with peripheral vascular disease (18). $A$ decrease in toe systolic blood pressure in patients suffering from severe peripheral vascular disease was shown by Conrad and Green (19). Carter showed that the toe systolic blood pressure correlated better with severe ischaemia than the ankle systolic blood pressure (20). This finding was confirmed by other investigators $(21,22)$.

\section{Methods}

Toe systolic blood pressure measurements were carried out using a photoplethysmograph (Hewlett-Packard, Type 7830A). This device contains a photoelectric transducer, consisting of a light-emitting diode, operating in the near infrared portion of the spectrum, and a photosensor. The amount of reflected light, detected by this photosensor, varies inversely with the absorption of light by hemoglobin, which in turn is proportional to the blood volume present in the part of the skin under investigation. The output was displayed as a series of pulse contours, synchronized with the heart-beat.

\subsubsection{Protocol of ankle systolic blood pressure (ASBP), ankle-to-brachial systolic blood pressure index (ABI), toe systolic blood pressure (TSBP) and toe-to-brachial systolic blood pressure index (TBI) measurements}

Smoking was not allowed for at least 2 hours prior to the start of the investigation. The following parameters were determined after the subjects had acclimatized and rested in the supine position for 15 minutes in a room with an ambient temperature between 22 and $25^{\circ} \mathrm{C}$ :

\section{Ankle systolic blood pressure (ASBP), expressed in $\mathrm{mm} \mathrm{Hg}$.}

A standard sized pneumatic cuff of $12 \mathrm{~cm}$ in width, as recommended by the American Heart Association, was used (23). After applying the cuff around the ankle and inflating it to a suprasystolic level, the ankle systolic blood pressure was determined by assessing accurately the pressure value at which the first audible pulsation was obtained during gradual cuff deflation. 
2. Ankle-to-brachial systolic blood pressure index (ABI).

After wrapping the same pneumatic cuff around the arm and placing the Doppler probe over the brachial artery, the brachial systolic blood pressure (BSBP, expressed in mm Hg) was measured in the same way. The ratio of ASBP to BSBP was considered as ABI.

\section{Toe systolic blood pressure (TSBP), expressed in $\mathrm{mm} \mathrm{Hg}$.}

After a pneumatic cuff of 2 or $2.5 \mathrm{~cm}$ in width, depending on the length of the toe, was applied at the base of the first toe or the second toe in case of an amputation, the light-weighted photoplethysmograph was attached to the plantar side of that toe 22 with double-sided sticky tape. Then, after recording several pulsatile arterial waveforms, the cuff was inflated until the arterial blood flow was interrupted, as indicated by the disappearance of the pulsatile arterial waveforms. The pressure at which the pulsatile arterial waveforms did return during gradual cuff deflation was regarded aS TSBP. If no pulsatile arterial waveforms were present before inflating the cuff, TSBP was taken to be zero $\mathrm{mm} \mathrm{Hg}$. Toe systolic blood pressure measurements were performed in the supine position (TSBP (supine)) and in the sitting position with the legs dependent after all subjects had acclimatized for 15 minutes in this position (TSBP (sitting)).

\section{Toe-to-brachial systolic blood pressure index (TBI).}

The ratios of TSBP (supine) and TSBP (sitting) to BSBP were defined as TBI (supine) and TBI (sitting), respectively. Since the brachial systolic blood pressure is not significantly influenced by a change in posture, BSBP, as assessed in the supine position, was used to calculate both TBI (supine) and TBI (sitting) $(24,25)$.

\subsection{RESULTS}

\subsubsection{Results of arteriography}

Arteriography was performed in 62 patients. In 12 of these patients, however, the arteries below the knee could not be judged according to Morton. This was due to the fact that less than 4 arteries below the knee were visualized, because attention was focussed on the arteries above the knee and the distal popliteal artery (popliteal trifurcation). This resulted in 50 patients, whose arteriograms were available for this study. Twenty-two patients belonged to the F2-group and 28 patients belonged to the F3/4-group. For both groups the arteriographic classification, representing progressive degrees of macrocirculatory obstruction, is presented in Table 3.2 . 
Table 3.2 Arteriographic classification for the F2-group and the F3/4-group, representing progressive degrees of macrocirculatory obstruction.

\begin{tabular}{|c|c|c|c|c|c|c|c|}
\hline \multicolumn{2}{|c|}{ ARTERIOGRAPHY-GROUP } & 1 & 2 & 3 & 4 & 5 & 6 \\
\hline$F 2+F 3 / 4$ & $\mathrm{n}=50$ & 2 & 20 & 2 & 5 & 5 & 16 \\
\hline $\mathrm{F} 2$ & $\mathrm{n}=22$ & $\begin{array}{c}1 \\
(4 \%)\end{array}$ & $\begin{array}{c}16 \\
(73 \%)\end{array}$ & $\begin{array}{c}0 \\
(0 \%)\end{array}$ & $\begin{array}{c}3 \\
(14 \%)\end{array}$ & $\begin{array}{c}0 \\
(0 \%)\end{array}$ & $\begin{array}{c}2 \\
(9 \%)\end{array}$ \\
\hline $\mathrm{F} 3 / 4$ & $n=28$ & $\begin{array}{c}1 \\
(4 \%)\end{array}$ & $\begin{array}{c}4 \\
(14 \%)\end{array}$ & $\begin{array}{c}2 \\
(7 \%)\end{array}$ & $\begin{array}{c}2 \\
(7 \%)\end{array}$ & $\begin{array}{c}5 \\
(18 \%)\end{array}$ & $\begin{array}{c}14 \\
(50 \%)\end{array}$ \\
\hline
\end{tabular}

$\mathrm{F} 2=\mathrm{F} 2$-group, F3/4 = F3/4-group; $\mathrm{n}=$ number of patients .

Obstructed arteries above the knee (ARTERIOGRAPHY-GROUPS 2, 4 and 6) were seen in 21 out of the 22 patients of the F2-group (95\%), whereas severe obstructions in the arteries below the knee (ARTERIOGRAPHY-GROUPS 5 and 6) were present in only 2 patients of this group (9\%). In the F3/4-group, 20 out of 28 patients had obstructed arteries above the knee (ARTERIOGRAPHY-GROUPS 2, 4 and 6) (71\%), whereas 19 patients had severe obstructions in the arteries below the knee (ARTERIOGRAPHY-GROUPS 5 and 6) (68\%).

As expected, these findings indicate that in patients of the F2-group the obstructive process was mainly localized in the arteries above the knee, whereas in the majority of patients of the F3/4-group the arteries below the knee were also affected.

\subsubsection{Results of ankle systolic blood pressure (ASBP) and ankle-to-brachial systolic blood pressure index (ABI) measurements in the supine position}

The median ASBP of the control-group was $153 \mathrm{~mm} \mathrm{Hg}$ (Figure 3.1). Patients of the F2-group and the F3/4-group had a median ASBP of $73 \mathrm{~mm} \mathrm{Hg}$ and $60 \mathrm{~mm}$ $\mathrm{Hg}$, respectively.

The ASBP values differed significantly between the 3 groups. Only one patient of the F2-group had an ASBP, which fell within the range of ASBP values of the control-group. A considerable overlap existed between the ranges of ASBP values of the F2-group and the F3/4-group.

The median ABI of the control-group, the F2-group and the F3/4-group was $1.15,0.50$ and 0.35 , respectively (Figure 3.2).

A significant difference in $\mathrm{ABI}$ existed between the 3 groups. The ranges of $\mathrm{ABI}$ values of subjects of the control-group and patients with peripheral vascular 


\section{ASBP in $\mathrm{mm} \mathrm{Hg}$ (supine position)}

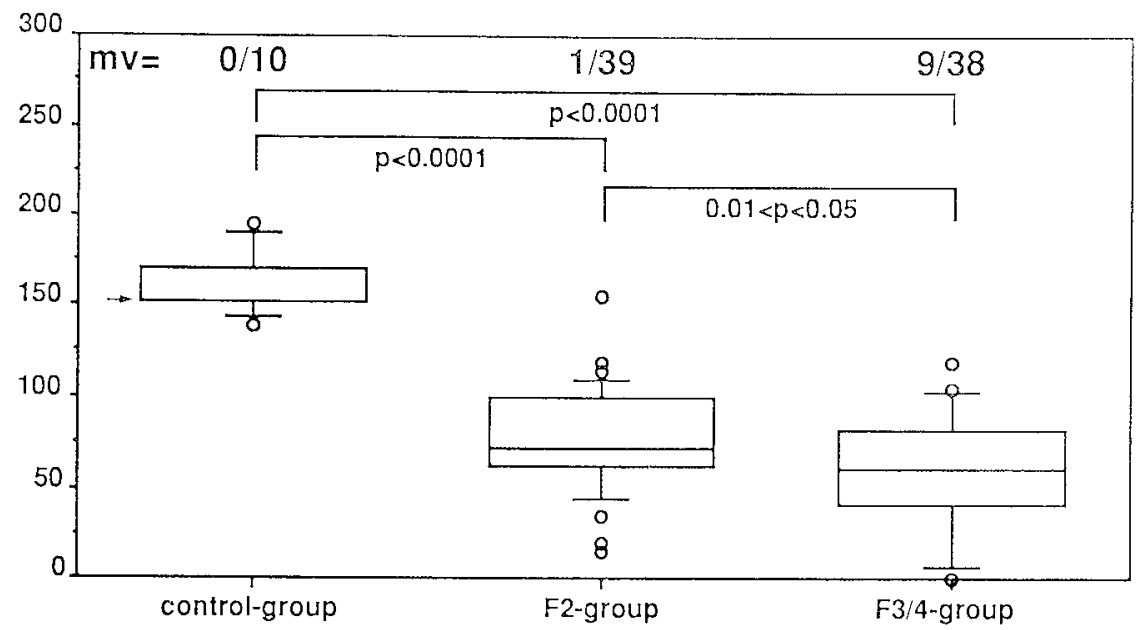

Figure 3.1 Ankle systolic blood pressure (ASBP) in the supine position in healthy subjects (control-group) and in patients with various degrees of peripheral vascular disease according to Fontaine's classification (F2-group and F3/4-group), as shown by box plots; $m v=$ missing value $(s) ; \rightarrow=$ median value.

\section{$A B I$ (supine position)}

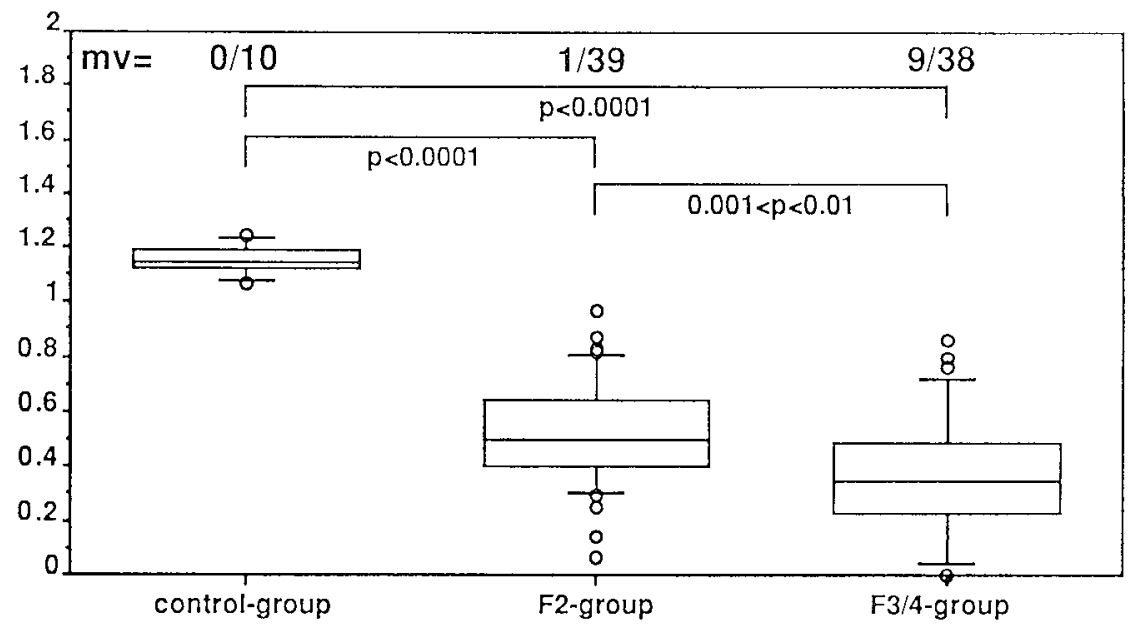

Figure 3.2 Ankle-to-brachial systolic blood pressure index (ABI) in the supine position in healthy subjects (control-group) and in patients with various degrees of peripheral vascular disease according to Fontaine's classification (F2-group and F3/4-group), as shown by box plots; $m v=$ missing value $(\mathrm{s})$. 
disease did not overlap, whereas the ranges of ABI values of the F2-group and the F3/4-group overlapped considerably.

In 1 patient of the F2-group and 9 patients of the F3/4-group no ASBP could be determined and hence no ABI could be calculated, because of incompressibility of the ankle arterics probably caused by arterial wall rigidity (Mönckebery s sclerosis).

\subsubsection{Results of toe systolic blood pressure (TSBP) and toe-to-brachial systolic blood pressure index (TBI) measurements in the supine and sitting position}

\section{Supine position}

The median TSBP and TBI of subjects belonging to the control-group was $128 \mathrm{~mm}$ $\mathrm{Hg}$ and 0.89 , respectively (Figures 3.3 and 3.4). Patients of the F2-group had a median TSBP of $35 \mathrm{~mm} \mathrm{Hg}$ and a median TBI of 0.26 . In patients of the F3/4group the median TSBP and TBI was $0 \mathrm{~mm} \mathrm{Hg}$ and 0.00 , respectively.

Both the TSBP and TBI differed significantly between the 3 groups. TSBP and TBI values of respectively 6 and 4 patients of the F2-group fell within the range of the control-group. The ranges of TSBP and TBI values of the F2-group and the F3/4-group showed a considerable overlap.

\section{Sitting position}

The median TSBP and TBI of subjects of the control-group was $203 \mathrm{~mm} \mathrm{Hg}$ and 1.49, respectively (Figures 3.5 and 3.6). Patients of the F2-group had a median TSBP of $143 \mathrm{~mm} \mathrm{Hg}$ and a median TBI of 0.95 . The median TSBP of patients belonging to the F3/4-group was $65 \mathrm{~mm} \mathrm{Hg}$, while their median TBI was 0.41 .

A statistically significant difference in TSBP and TBI existed between the 3 groups. The ranges of TSBP and TBI values of healthy subjects and patients with moderate peripheral vascular disease (F2-group) overlapped considerably. The overlap between the ranges of TSBP values of the F2-group and the F3/4-group was small, as compared to the overlap between the ranges of TBI values of both groups. 
TSBP in $\mathrm{mm} \mathrm{Hg}$ (supine position)

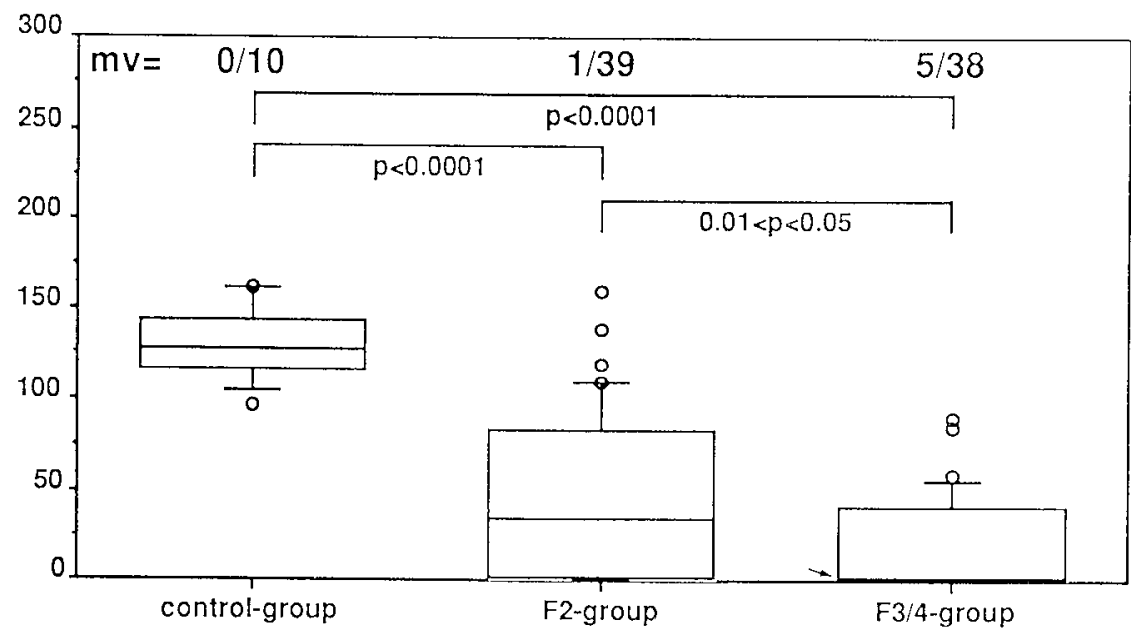

Figure 3.3 Toe systolic blood pressure (TBSP) in the supine position in healthy subjects (control-group) and in patients with various degrees of peripheral vascular diseatse according to Fontaine's classification (F2-group and F3/4-group), as shown by box plots; mv = missing value $(s) ; \rightarrow=$ median value.

\section{TBI (supine position)}

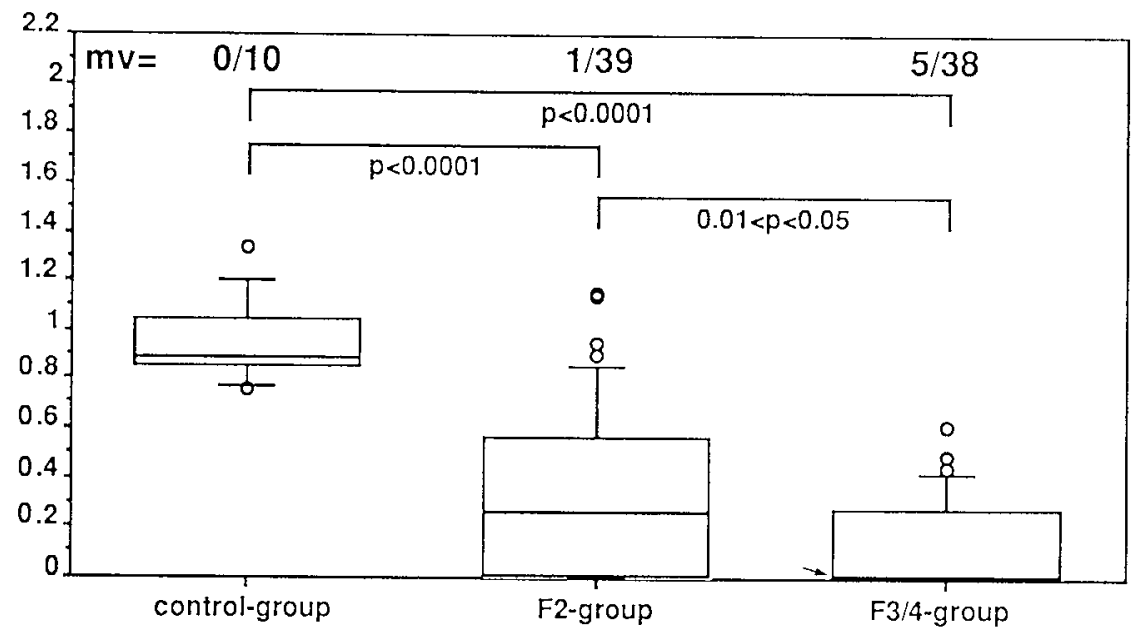

Figure 3.4 Toe-to-brachial systolic blood pressure index (ТВI) in the supine position in healthy subjects (control-group) and in patients with various degrees of peripheral vascular disease according to Fontaine's classification (F2-group and F3/4-group), as shown by box plots; $\mathrm{mv}=$ missing value $(\mathrm{s}) ; \rightarrow=$ median value . 


\section{TSBP in $\mathrm{mm} \mathrm{Hg}$ (sitting position)}

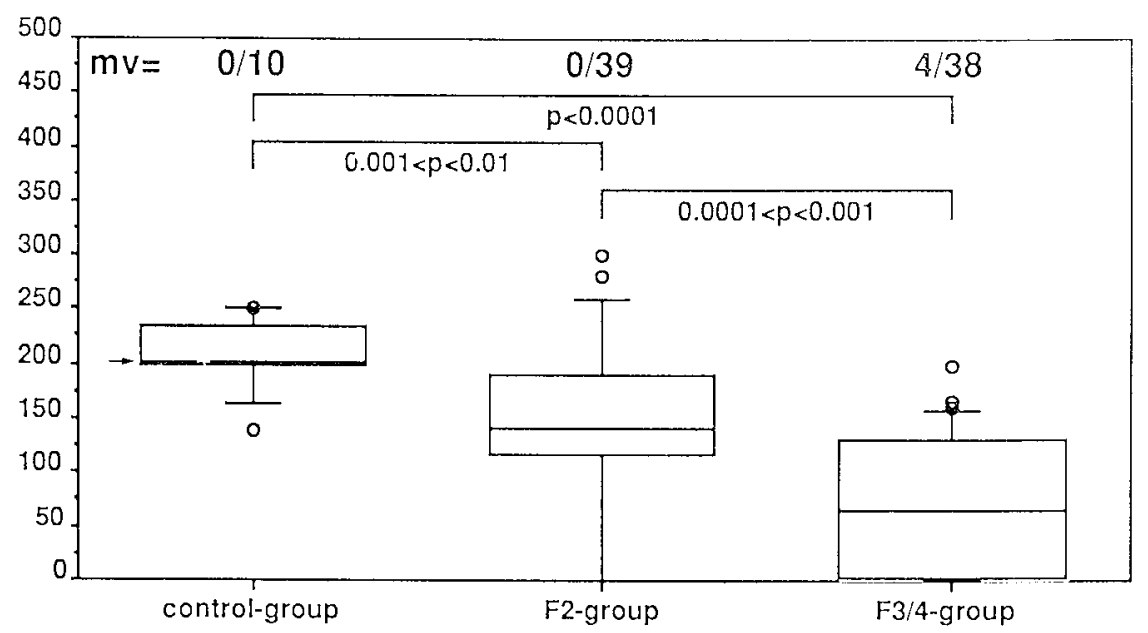

Figure 3.5 Toe systolic blood pressure (TBSP) in the sitting position in healthy subjects (control-group) and in patients with various degrees of peripheral vascular disease according to Fontaine's classification (F2-group and F3/4-group), as shown by box plots; mv = missing value $(s) ; \rightarrow=$ median value.

\section{TBI (sitting position)}

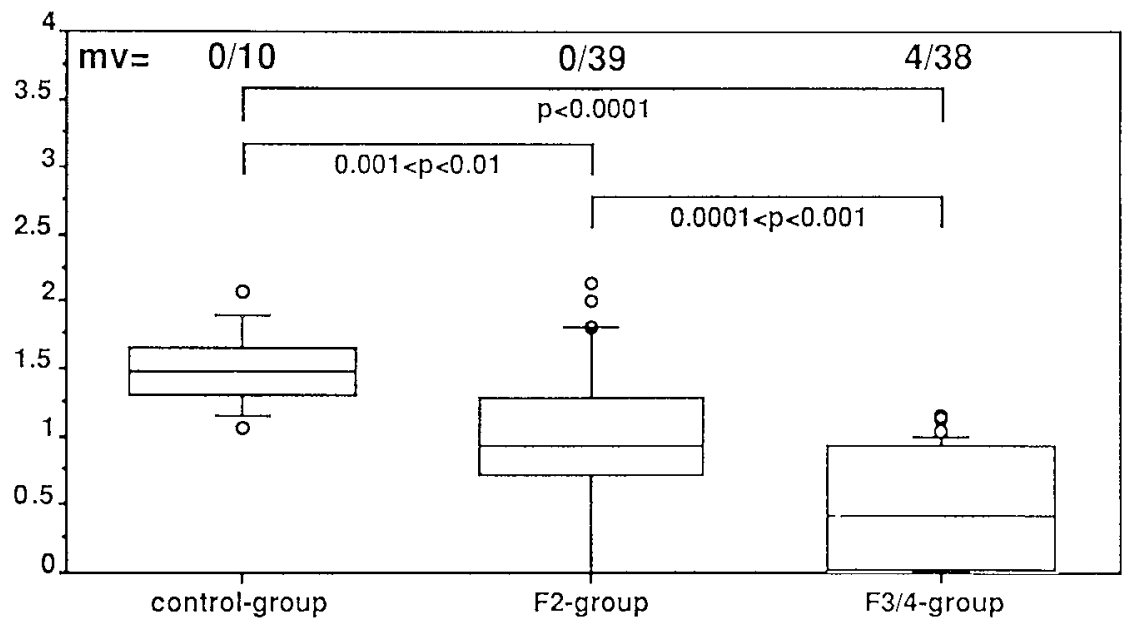

Figure 3.6 Toe-to-brachial systolic blood pressure index (TBI) in the sitting position in healthy subjects (control-group) and in patients with various degrees of peripheral vascular disease according to Fontaine's classification (F2-group and F3/4-group), as shown by box plots; mv = missing value(s). 
ASBP in $\mathrm{mm} \mathrm{Hg}$ (supine position)

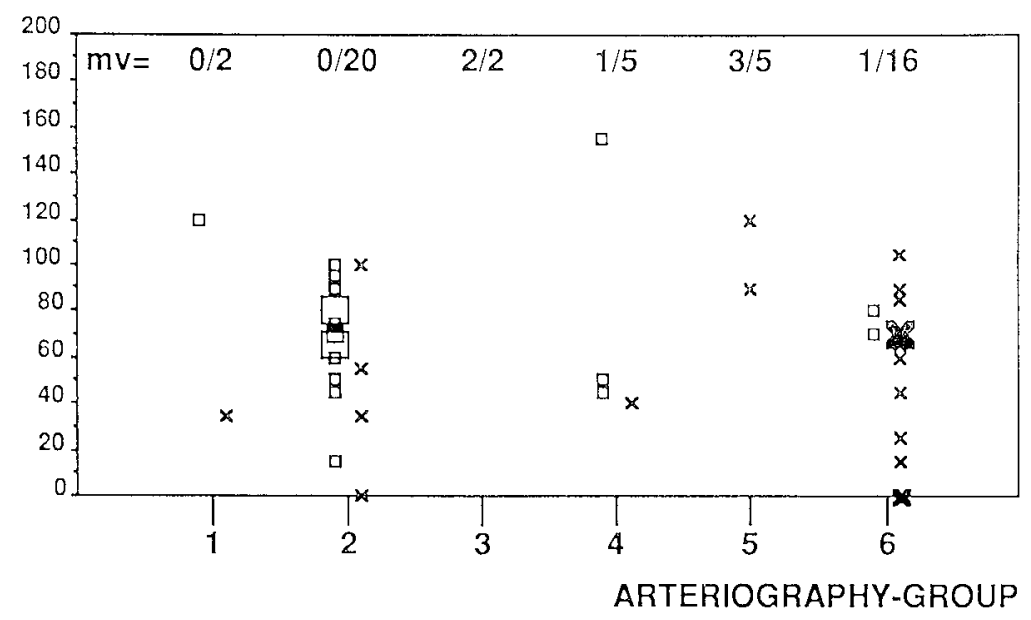

Figure 3.7 Scatter plot of the ankle systolic blood pressure (ASBP) in the supine position for the various ARTERIOGRAPHY-GROUPS, representing progressive arteriographic degrees of macrocirculatory obstruction; $\square=F 2$-group, $x=$ F3/4-group. The size of the symbol corresponds to the number of data points that coincide at that location; abscissa: 1 = ARTERIOGRAPHY-GROUP 1, 2 = ARTERIOGRAPHY-GROUP 2, etc; mv = missing value(s).

\subsubsection{Relation between ankle systolic blood pressure (ASBP), ankle-to-brachial systolic blood pressure index ( $\mathrm{ABI}$ ), toe systolic blood pressure (TSBP), toe-to-brachial systolic blood pressure index (TBI) and arteriography}

In Figures 3.7-3.12, ASBP, ABI, TSBP and TBI are rearranged according to the corresponding ARTERIOGRAPHY-GROUPS, representing progressive arteriographic degrees of macrocirculatory obstruction. The absence of data for the ASBP and ABI in ARTERIOGRAPHY-GROUP 3 is explained by the presence of incompressible ankle arteries in both patients belonging to this ARTERIOGRAPHY-GROUP. ASBP and ABI values of the various ARTERIOGRAPHY-GROUPS showed a considerable overlap, as shown in Figures 3.7 and 3.8 .

A considerable overlap also existed between TSBP and TBI values of the 6 ARTERIOGRAPHY-GROUPS in the supine as well as in the sitting position (Figures 3.9-3.12). 
ABI (supine position)

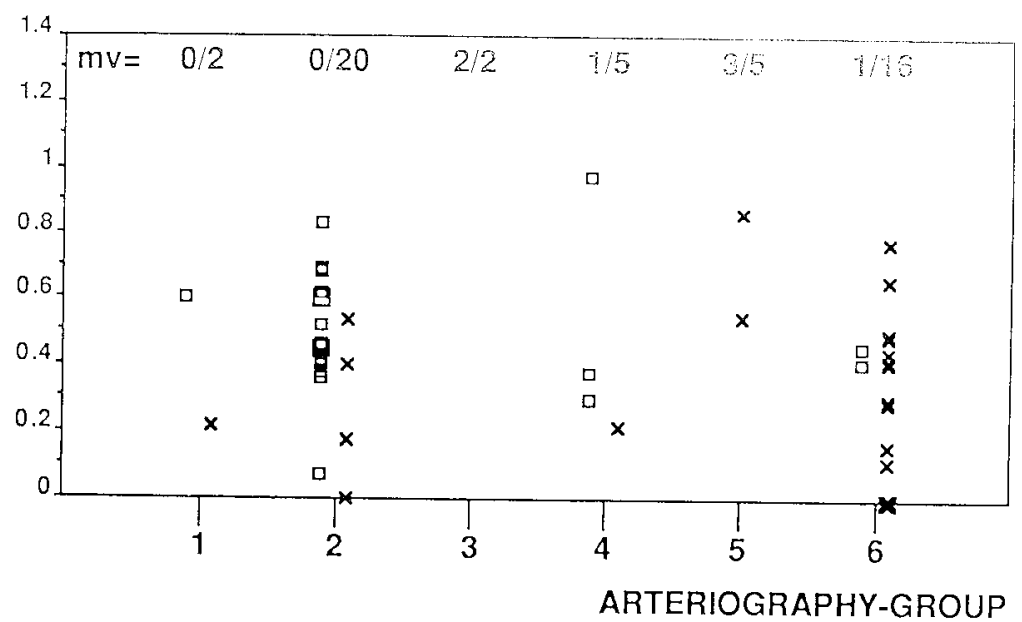

Figure 3.8 Scatter plot of the ankle-to-brachial systolic blood pressure index $(A B I)$ in the supine position for the various ARTERIOGRAPHY-GROUPS, representing progressive arteriographic degrees of macrocirculatory obstruction; $\square=F 2$-group, $x=$ F3/4-group. The size of the symbol corresponds to the number of data points that coincide at that location; abscissa: $1=$ ARTERIOGRAPHY-GROUP 1, 2 = ARTERIOGRAPHY-GROUP 2, etc; mv = missing value(s).

TSBP in $\mathrm{mm} \mathrm{Hg}$ (supine position)

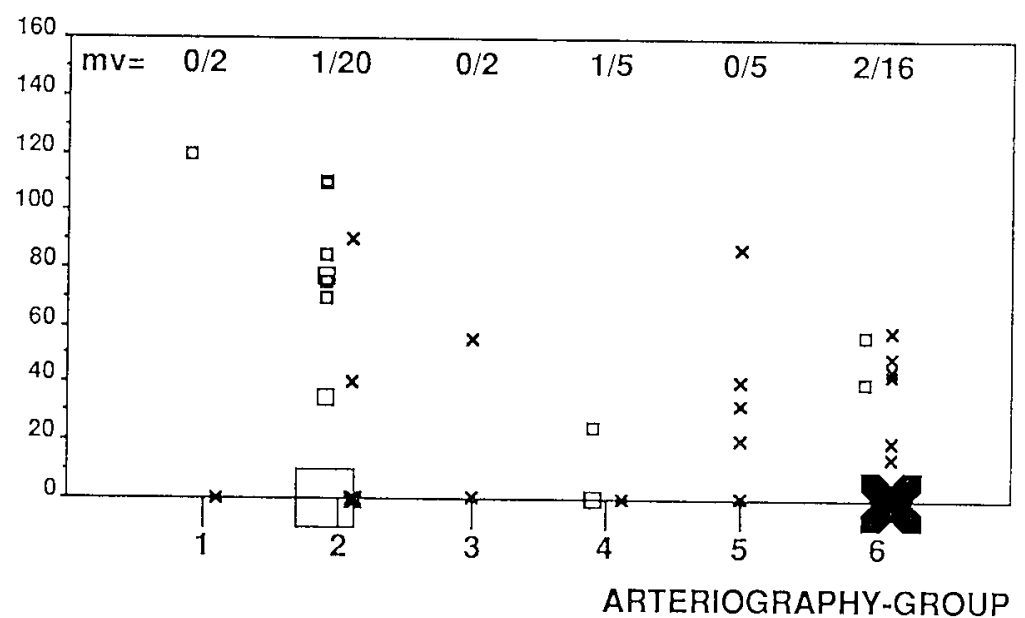

Figure 3.9 Scatter plot of the toe systolic blood pressure (TSBP) in the supine position for the variouS ARTERIOGRAPHY-GROUPS, representing progressive arteriographic degrees of macrocirculatory obstruction; $\square=$ F2-group, $x=$ F3/4-group. The size of the symbol corresponds to the number of data points that coincide at that location; abscissa: $1=$ ARTERIOGRAPHY-GROUP 1, 2 = ARTERIOGRAPHY-GROUP 2, etc; mv = missing value(s). 
TBI (supine position)

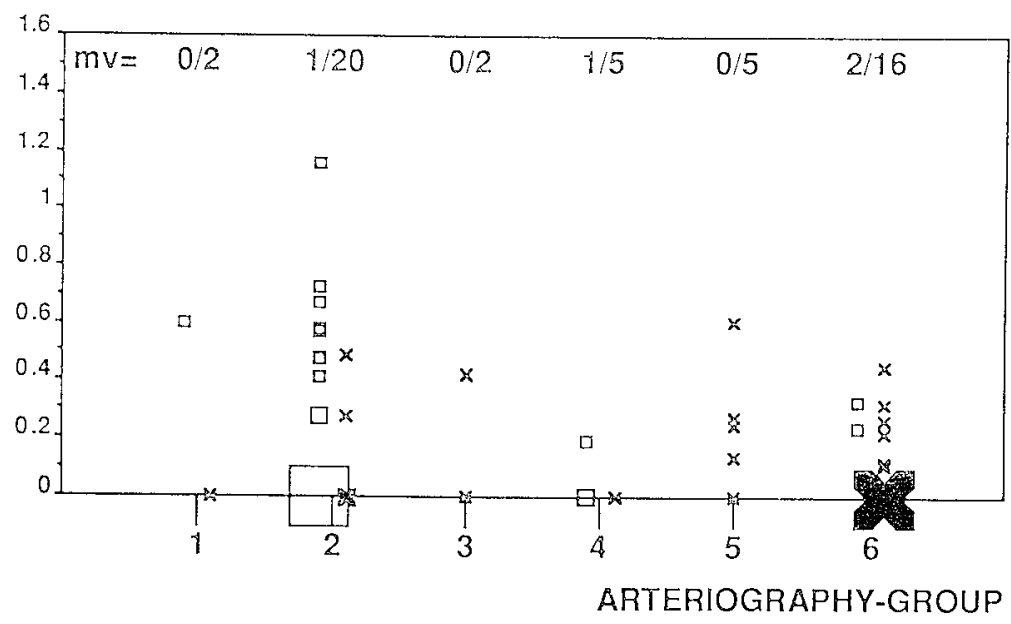

Figure 3.10 Scatter plot of the toe-to-brachial systolic blood pressure index (TBI) in the supine position for the various ARTERIOGRAFHY-GROUPS, representing progressive arteriographic degrees of macrocirculatory obstruction; $\square=F 2$-group, $x=F 3 / 4$-group. The size of the symbol corresponds to the number of data points that coincide at that location; abscissa: $1=$ ARTERIOGRAPHY-GROUP 1, 2 = ARTERIOGRAPHY-CRROUP 2, etc; mv = missing value(s).

TSBP in $\mathrm{mm} \mathrm{Hg}$ (sitting position)

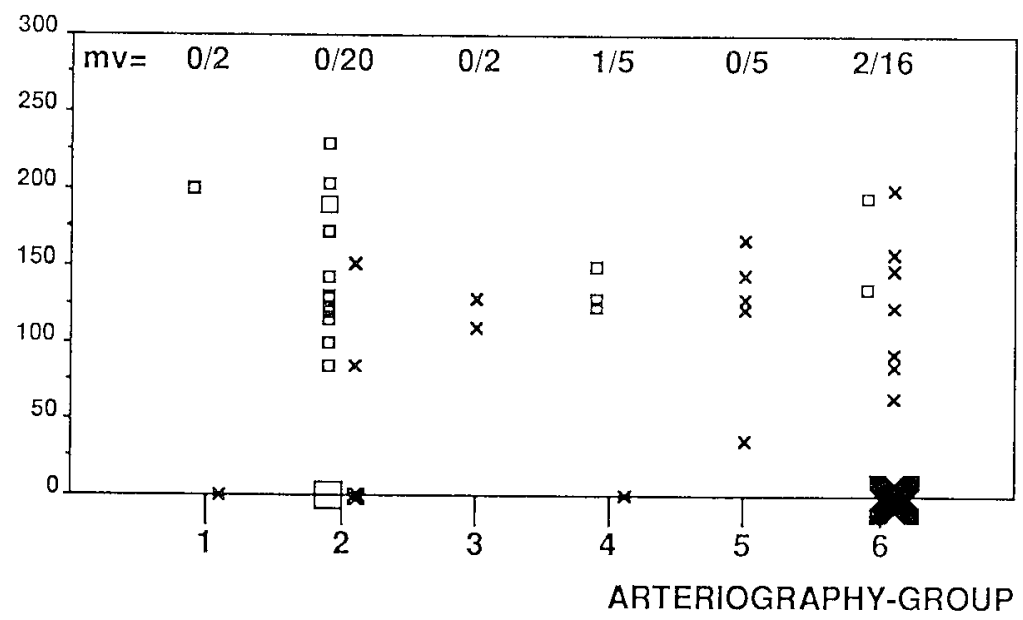

Figure 3.11 Scatter plot of the toe systolic blood pressure (TSBP) in the sitting position for the various ARTERIOGRAPHY-GROUPS, representing progressive arteriographic degrees of macrocirculatory obstruction; $\square=$ F2-group, $x=$ F3/4-group. The size of the symbol corresponds to the number of data points that coincide at that location; abscissa: $]=$ ARTERIOGRAPHY-GROUP 1, 2 = ARTERIOGRAPHY-GROUP 2, etc; mv = missing value(s). 
TBI (sitting position)

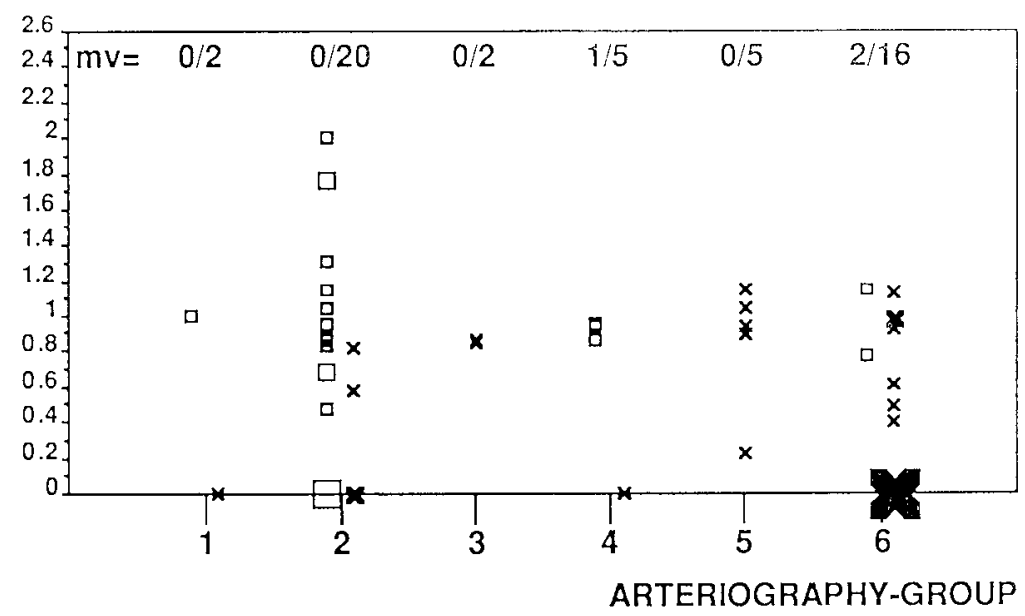

Figure 3.12 Scatter plot of the toe-to-brachial systolic blood pressure index (TBI) in the sitting position for the various ARTERIOGRAPHY-GROUPS, representing progressive arteriographic degrees of macrocirculatory obstruction; $\square=$ F2-group, $x=$ F3/4-group. The size of the symbol corresponds to the number of data points that coincide at that location; abscissa: $1=$ ARTERIOGRAPHY-GROUP 1, 2 = ARTERIOGRAPHY-GROUP 2, etc; mv = missing value(s).

\subsection{DISCUSSION}

A complete separation between healthy subjects on the one hand and patients with peripheral vascular disease (F2-group and F3/4-group) on the other can be made with the use of the ABI in the supine position. This, however, is not the case when the ASBP in the supine position, or the TSBP and TBI in the supine or sitting position are used. The progression from moderate (F2-group) to severe peripheral vascular disease (F3/4-group), however, is reflected in the ASBP, ABI, TSBP and TBI values of both patient groups, but the overlap between the two groups is substantial. The present results of ASBP and TSBP measurements in patients with severe peripheral vascular disease are in accordance with the observations of Carter, supporting his statement that the TSBP is a better indicator of severe ischaemia than the ASBP (20). When changing from the supine to the sitting position, the complete overlap between TSBP values of patients with moderate and severe peripheral vascular disease decreases to such an extent that the TSBP (sitting) provides a better estimation of the degree of peripheral vascular disease, as compared to ankle and toe systolic blood pressure measurements in the supine position. 
ABI values above 0.80 in 4 patients with moderate peripheral vascular discase may be explained by the existence of well-developed collateral pathways (26). The high ASBP value of $155 \mathrm{~mm} 1 \mathrm{gg}$ in 1 patient, which is in the range of $A S B P$ values of healthy subjects, can probably be explained by the combination of well-developed collaterals and the high systemic systolic blood pressure of 160 mm Hg. Thirty-two patients with moderate peripheral vascular disease $(84 \%)$ had a TSBP (supine) between 0 and $100 \mathrm{~mm} \mathrm{Hg}$, which is in agreement with the finding of Gundersen (27). In the remaining 6 patients, who had a TSBP (supine) above $100 \mathrm{~mm} \mathrm{Hg}$, the TSBP (supine) was higher than $(\mathrm{n}=5)$ or equal to $(\mathrm{n}=1)$ the ASBP, which indicates overestimation of the TSBP (supine). Since rigidity of digital arteries due to calcification is uncommon and seems not to interfere with TSBP measurements, the overestimated TSBP (supine) values probably resulted from the application of too small a cuff $(26,28,29)$. In 4 of the 6 patients the overestimated values of TSBP (supine) caused the TBI (supine) to be within the range of healthy subjects.

In 9 patients with severe peripheral vascular disease (24\%) the existence of arterial wall rigidity (Mönckeberg's sclerosis) interfered with ASBP measurements to such an extent that no ASBP could be determined. Eight of these 9 patients suffered from diabetes, which confirms that arterial wall stiffness is more likely to occur in diabetics (26). Four patients suffering from severe peripheral vascular disease had an $A B I$ higher than $0.65(0.66,0.77,0.80,0.86)$, which was reported by Yao to be the upper limit (16). The high ABI values in these 4 patients, 3 of whom had diabetes, are probably caused by overestimation of their ASBP, due to the presence of arterial wall rigidity. Three of these 4 patients ( 2 diabetics, 1 non-diabetic), of whom the arteries below the knee could be reviewed arteriographically, showed a Morton-stage 3 of outflow obstruction (ARTERIOGRAPHYGROUPS $5(n=1)$ and $6(n=2)$, indeed suggesting the presence of arterial wall rigidity. Twenty-four per cent of the patients with severe ischacmia $(n=8)$ had a TSBP (supine) above $40 \mathrm{~mm} \mathrm{Hg}$, which is in agreement with the observations of Gundersen, who reported a percentage of 18 with this value (27). Since 7 of these 8 patients had a TBI (supine) below 0.50 (range: $0.22-0.49$ ), their high TSBP (supine) is probably caused by a relatively high systemic systolic blood pressure.

The arteriographic degree of macrocirculatory obstruction does not correspond to ASBP and ABI values or to TSBP and TBI values in the supine and sitting position, as indicated by the considerable overlap between the different ARTERIOGRAPHY-GROUPS. The tendency of the TBI (supine) to decrease in patients with a more severe degree of arterial obstruction is in accordance with the finding of Lezack and Carter (30). They reported a correlation between the TBI, as measured in the supine position, and the severity of the arteriographic lesions, although also in their study a considerable overlap was shown. 


\subsection{CONCLUSION}

It can be concluded that the TSBP, and especially the TSBP in the siting pusition, is the most appropriate variable to estimate the degree of peripheral vascular disease. When performing TSBP measurements, however, the possibility of overestimation due to the application of too small a cuff has to be taken into account, especially if pressure values at the ankle level appear to be lower. 
1. Haschek E, Lindenthal OT. Fin Beitrag zur praktischen Verwerthung der Photografie nach Röntgen. Wien Klin Wochenschr 1896;9:63-4.

2. Brooks B. Intra-arterial injection of sodium iodid. Preliminary report. JAMA 1924;82:1016-9.

3. Dos Santos R, Lamas AC, Pereira-Caldas J. L'artériographie des membres de l'aorte et de ses branches abdominales. Bull Mem Soc Natl Chir 1929;55:587601.

4. Fariñas PL. $\wedge$ new technique for the arteriographic examination of the abdominal aorta and its branches. AJR 1941;46:641-5.

5. Seldinger SI. Catheter replacement of the needle in percutaneous arteriography. A new technique. Acta Radiol 1953;39: 368-76.

6. Neiman IL, Yao JST, eds. Angiography of vascular disease. New York: Churchill Livingstone Inc., 1985.

7. Janevski BK. Angiography of the upper extremity. The Hague: Martinus Nijhoff Publishers, 1982.

8. Johnston KW, Maruzzo BC, Cobbold RSC. Doppler methods for quantitative measurement and localization of peripheral arterial occlusive disease by analysis of the blood flow velocity waveform. Ultrasound Med Biol 1978; 4:209-23.

9. Morton DL, Ehrenfeld WK, Wylie EJ. Significance of outflow obstruction after femoropopliteal endarterectomy. Arch Surg 1967;94:592-9.

10. Yao JST, Peterson LK, Payne K. Lower limb systolic pressure measurements: Technique and clinical applications. Inter Angio 1985;4:31-9.

11. Sumner DS, Strandness DE Jr. The relationship between calf blood flow and ankle blood pressure in patients with intermittent claudication. Surgery 1969; 65:763-71.

12. Carter SA. Clinical measurement of systolic pressures in limbs with arterial occlusive disease. JAMA 1969;207:1869-74.

13. Franklin DL, Schlegel W, Rushmer RF. Blood flow measured by Doppler frequency shift of back-scattered ultrasound. Science 1961;134:564-5.

14. Strandness DE Jr, McCutcheon EP, Rushmer RF. Application of a transcutaneous Doppler flowmeter in evaluation of occlusive arterial disease. Surg Gynecol Obstet 1966;122:1039-45.

15. Strandness DE Jr, Schultz RD, Sumner DS, Rushmer RF. Ultrasonic flow detection. A useful technique in the evaluation of peripheral vascular disease. Am J Surg 1967;113:311-20.

16. Yao ST. Haemodynamic studies in peripheral arterial disease. Brit J Surg 1970;57:761-6. 
17. Zierler RE. Strandness DE Jr. Ultrasonic techniques of lower extemity arterial diagnosis. In: Zwiebel WJ, ed. Introduction to vascular ultassonography. New York: Grune ie Stratton Inc., 1982:251-72.

18. Formijne P. Investigation of the patency of peripheral arteries. Am liear $j$ $1934: 10: 1-16$.

19. Conrad MC, Green HD. Hemodynamics of large and small vessels in peripheral vascular disease. Circulation 1964;29;847-53.

20. Carter SA. The definition of critical ischaemia of the lower limb and distal systolic pressures. Br J surg 1983;70:188-9.

21. Ramsay DE, Manke DA, Sumner DS. Toe blood pressure. A valuable adjunct to ankle pressure measurement for assessing peripheral arterial discase. J Cardiovase Surg 1983;24:43-8.

22. Vincent DG, Salles-Cumha SX, Bernhard VM, Towne JB. Noninvasive assessment of toe systolic pressures with special reference to diabetes mellitus. J Cardiovasc Surg 1983;24:22-8.

23. Kirkendall WM, Feinleib M, Freis ED, Mark AL (Subcommittee of the AIIA postgraduate education committee). Recommendations for human blood pressure determination by sphygmomanometers. Circulation 1980;62:1146A$1155 \mathrm{~A}$.

24. Guyton AC. Physics of blood, blood flow, and pressure: Hemodynamics. In: Guyton AC, ed. Textbook of medical physiology. Philadelphia: W.B. Saunders Company, 1976;222-36.

25. Coleman TG. Regulatie van de bloeddruk en hypertensie. In: Struyker Boudier HAJ, ed. Regulatie van de bloeddruk. Utrecht: Wetenschappelijke uitgeverij Bunge, 1979;77-89.

26. Carter SA. Role of pressure measurements in vascular discase. In: Bernstein EF, ed. Noninvasive diagnostic techniques in vascular disease. St.Louis: The C.V. Mosby Company, 1985;513- 44.

27. Gundersen J. Segmental measurements of systolic blood pressure in the extremities including the thumb and the great toe. Acta Chir Scand 1972; suppl 426:1-90.

28. Bone GE, Pomajzl MJ. Toe blood pressure by photoplethysmography: An index of healing in forefoot amputation. Surgery 1981;89:569-74.

29. French-Sherry E et al. Cuff artifact in digital pressures. Bruit 1981;5:33-5.

30. Lezack JD, Carter SA. The relationship of distal systolic pressures to the clinical and angiographic findings in limbs with arterial occlusive disease. Scand J Clin Lab Invest 1973;31(suppl 128):97-101. 


\section{CHAPTER 4}

\section{SKIN MICROCIRCULATION}

In this chapter the investigation of the total and nutritional skin microcirculation with the use of transcutaneous oxygen pressure $\left(t c \mathrm{pO}_{2}\right)$ monitoring and intravital skin capillary microscopy, respectively, is described.

\subsection{INVESTIGATIVE TECHNIQUES}

\subsection{1 $\mathrm{TcpO}_{2}$ monitoring}

Gerlach was probably the first to show the absorption of oxygen through the intact human skin in 1851 by measuring chemically a reduction in the amount of oxygen 24 hours after he had tied a horse bladder, filled with air, firmly to his chest (1).

The membrane-covered polarographic oxygen electrode, constructed by Clark in 1956, made it possible to measure oxygen pressure $\left(\mathrm{pO}_{2}\right)$ routinely (2). Measurements of the $\mathrm{pO}_{2}$ at the skin surface with the use of such a membranecovered platinum electrode, as performed by Evans and Taylor in 1967, showed $\mathrm{pO}_{2}$ values at the surface of the non-hyperaemized adult skin to be close to zero $\mathrm{mm} \mathrm{Hg} \mathrm{(3).} \mathrm{Higher} \mathrm{tcpO} \mathrm{O}_{2}$ values as a result of a better oxygenation of the skin were obtained by local skin heating, causing skin hyperaemia due to vasodilation of skin blood vessels and a shift of the oxyhaemoglobin curve to the right $(4,5)$.

In healthy newborns a close relation was found between arterial oxygen pressure $\left(\mathrm{paO}_{2}\right)$ values and $\mathrm{tcpO}_{2}$ values, as measured at an electrode core temperature of $43^{\circ} \mathrm{C}(6)$. This close relation was not only observed in healthy neonates, but also in sick infants with mild hypotension, hypothermia or anaemia, indicating the general applicability of the method (7). Subsequently, tcpO $\mathrm{O}_{2}$ measurements have become the method of choice to monitor $\mathrm{paO}_{2}$ continuously and non-invasively in newborn infants. In adults t $\mathrm{CPO}_{2}$ monitoring can be applied to perceive the development of hypoxia and shock (8). 
The first tepo meatsurments to estmate oxyen delivery to the shin in patients with arterial obstructive disease of the lower limb were probably pertomed by Tonnesen in 1978 (9). Ile reported zero tepO2 values at rest at $44^{\circ} \mathrm{C}$ in paticnts with moderate and severe rest pain (stage 3 according to fontaine), although skin isotope clearance indicated the presence of some blood supply to the skin. Furthermore, it hats been shown that during the inhalation of $100 \%$ of oxygen the rate of rise of $t \mathrm{CPO}_{2}$ was significantly reduced and the maximum level of $1 \mathrm{cpO}_{2}$ was considerably lower in patients with severe peripheral vascular disease (stages 3 and 4 according to Fontaine) (10,11). Despite considerable overlap, a statistically significant difference in $\mathrm{tepO}_{2}$ at rest at $44-45^{\circ} \mathrm{C}$ has been shown to be present between healthy subjects and patients with intermittent claudication (stage 2 according to Fontaine) (12-14). At $44-45^{\circ} \mathrm{C}$, the tepO 2 response to the release of a transient arterial occlusion and to exercise, however, showed a more significant difference with a considerably smaller overlap (13-15).

A severely impaired oxygen supply to the skin often results in ischaemic skin necrosis, which finally may lead to amputation. The optimum level of amputation can be selected by assessing skin viability with the use of $t c \mathrm{P}_{2}$ measurements. $A$ tepO $\mathrm{O}_{2}$ value at rest of $40 \mathrm{~mm} \mathrm{Hg}$ or more at the site of amputation (electrode core temperature $\left.44-45^{\circ} \mathrm{C}\right)$ generally leads to successful healing of the stump $(16,17)$. Since treatment of patients with peripheral vascular disease intends to restore perfusion and hence oxygen supply to the skin, tcpO $\mathrm{O}_{2}$ measurements are suitable for the evaluation of therapy (18-21).

\section{Methods}

In the present study $\operatorname{tcpO}_{2}$ was measured polarographically. This method is based on the reduction of oxygen at a platinum cathode when a voltage is applied between this cathode and an anode. The following electrochemical reaction occurs when a platinum cathode and a silver anode are used:

At the cathode: $\mathrm{O}_{2}+2 \mathrm{H}_{2} \mathrm{O}+4 \mathrm{e}^{-} \rightarrow 4 \mathrm{OH}^{-}$

At the anode: $\quad 4 \mathrm{Ag} \rightarrow 4 \mathrm{Ag}^{+}+4 \mathrm{e}^{-}$.

The resulting electrical current is proportional to the oxygen tension at the skin surface. Although oxygen electrodes consume oxygen, the amount consumed can practically be ignored when cathodes with a very small diameter are used.

Two TCM2 TC OXYGEN MONITORS (Radiometer, Copenhagen), each connected to a $\operatorname{tcpO}_{2}$ electrode, were used in this study. Both tcpO $\mathrm{O}_{2}$ electrodes combine in one and the same unit: a Clark-type oxygen electrode and a heating element combined with a temperature sensor to ensure a constant electrode core temperature of $44^{\circ} \mathrm{C}$. The Clark-type oxygen electrodes consist of a platinum 
cathode surrounded by a silver anode. A microcomputer system converts the currents, generated by the two tep $\mathrm{O}_{2}$ electrodes, into $\mathrm{pO}_{2}$ values, expressed in mm Hg (range: 0-999 $\mathrm{mm} \mathrm{Hg}$ ). Since zero-current drift was minimal and stability good, only a single-point calibration procedure before the start of every new measurement had to be carried out. Furthermore, both tep $\mathrm{O}_{2}$ electrodes were remembranized every two weeks. Data were recorded with the use of a TCM200 TC RECORDER at a chart speed of $0.5 \mathrm{~cm} / \mathrm{min}$. TCpO $\mathrm{O}_{2}$ measurements were performed at an intact part of the skin at the dorsum of the lirst metatarsophalangeal joint of the foot of interest. In addition, a reference tep $\mathrm{O}_{2}$ value was determined in the left subclavian region of the chest, which in general is well perfused, to be informed of the systemic level of skin oxygen delivery. Before securing the electrodes to the patient, the skin at the selected measuring sites was shaved, if necessary, and degreased with alcohol. Then fixation rings were placed on these measuring sites. Before firmly mounting both electrodes a contact liquid was put on the skin inside these rings. The probe cables were secured to the skin with surgical tape at appropriate distance from the measuring sites.

\subsubsection{Intravital skin capillary microscopy}

The first observations of capillaries and the red blood cells inside them were made in animals by the Dutch microscopist van Leeuwenhock (1632-1723) and the Italian anatomist Malphigi (1628-1694) in the 17th century (22,23). In human beings the microcirculation was probably investigated for the first time by the famous Dutch physician Boerhaave (1668-1738) at the level of the bulbar conjunctiva (22). The development of new biomicroscopic techniques allowed a more detailed visualization of the human microvessels. $A$ microscope with incident illumination was used by Hueter in 1879 to investigate the capillaries of the human lip (24). Beautiful pictures of skin capillaries in the back of the hand and the finger nailfold were obtained by Lombaid in 1912 by improving the transparency of the skin with a thin layer of glycerine or a transparent oil (25). Intravital skin capillary microscopy was also used to measure capillary blood pressure. Instead of observing colour changes when pressure was applied to the skin, capillary blood pressure was measured by taking as criterion the sudden sharp forward acceleration of corpuscles after lowering the pressure on the underlying skin, which had caused reversed corpuscular flow (26). The first photographic pictures of human capillaries were probably made by Weiß in 1916 (23). He constructed a device, that enabled him to examine and photograph capillaries in any part of the human skin. He reported that in patients with arteriosclerosis capillaries were elongated and narrowed and that the capillaries became more tortuous and blood velocity lower with increasing severity of arteriosclerosis. In his book 'Die Kapillaren der menschlichen Körperoberfläche in gesunden und kranken Tagen', published in 1922, Müller summarized the most 
important findings of his pupils Weif, Niehau. Parrisius and Leimberger (27). The time course of microcirculatory events in human capillaries, like the motion of corpuscles, was assessed by means of cinematography by Craw ford and Rosenberger in 1926 (28). In the fifties and sixties intravital skin capillary microscopy was especially applied in dermatological practice (29). The morphology of capillaries in a variety of diseases was described by Davis and Landau in their atlas 'Clinical capillary microscopy', published in 1966 (22). The diagnostic value of morphological intravital skin capillary microscopy, however, was doubted by Ryan (30).

Structural changes of skin capillaries at the medial part of the lower limb and at the dorsum of the foot in patients with arterial obstructive disease of the lower limb have been studied by Fagrell with the use of intravital skin capillary microscopy $(24,31,32)$. He noted a discrepancy between the macrocirculation and the nutritional skin microcirculation. In some patients a marked decrease in toe systolic blood pressure was not associated with structural changes of capillaries.

The first measurements of red blood cell velocity were probably performed by van Leeuwenhoek in 1674 . He measured a red blood cell velocity of approximately $2 \mathrm{~mm} / \mathrm{s}$ in capillaries of tadpole tails using the dimensions of a grain of sand as the unit of distance and the time, necessary to pronounce a four-syllable word, as the unit of time (33). In 1974, Bollinger and colleagues introduced a television microscopy technique and made sequential measurements of the red blood cell velocity in human nailfold capillaries possible (34). This technique allowed them to evaluate red blood cell velocity patterns and hence capillary haemodynamics in various clinical conditions by measuring the displacement of plasma gaps from successive video frames. Since that time, capillary haemodynamics and morphology have been studied in patients, especially in those with vasospastic and ischaemic hand phenomena (35-39). Because (red) blood cell velocities at rest showed a considerable variation, they could hardly be used for comparative studies between different subjects (40). The response to provocations, such as a period of ischaemia, caused by inflating a pneumatic cuff to a suprasystolic level, however, led to quite different responses in patients and healthy subjects (40-44). It has become a routine in microcirculatory research to apply provocations pertinent to the disease investigated.

\section{Methods}

Toe nailfold capillaries were investigated using an intravital skin capillary microscope (modified Leitz Orthoplan). To minimize disturbing reflections and to increase the transparency of the skin, a drop of paraffin oil was applied to the area of interest of the toe. Incident illumination was performed using a 100 Watt mercury vapour lamp (Calflex heat reflection filter; heat absorption filter; DCpower supply), an incident fluorescence illuminator (Leitz Ploemopak 2.1; mag- 
nification $1.25 x$ ), and a Leitz POL -cube (45). This L city POL-cube consists of a polarizer, a $50 \%$ mirror, postioned at $45^{\circ}$ to the optical axis, and a crossed analyzer. Images were directly projecked onto a TV camera (Philips, Type LDI $0400 / 01$; newvicon $X Q 1275,2 / 3$ inch tube), that could be rotated with respect to the optical axis of the system, and were displayed on a TV monitor (Philips, Type $2122 /(01)$. For off-line analysis the images were stored on tape via a videocassette recorder (Sony Betamax, model No. SL-C9ES). A L eitz objective I.4x (numerical aperture $=0.14$ ) was used for density measurements, while a Leit $\not$ objective L $10 \times$ (numerical aperture $=0.30$ ) was used for velocity and diameter measurements. The final optical magnification was $5 \times$ and $12.5 \times$, respectively. The calculated interline spacing on the monitor was 5 and $2 \mu \mathrm{m}$, respectively.

\subsubsection{Protocol of tepO $\mathrm{O}_{2}$ monitoring and int ravital skin capillary microscopy}

\section{Protocol of tepO $\mathrm{O}_{2}$ monitoring}

After all subjects had acclimatized and rested in the supine position for 15 minutes in a room where the ambient temperature was kept constant between 22 and $25^{\circ} \mathrm{C}$, $\mathrm{tcpO}_{2}$ monitoring was started. Smoking was not permitted for at least a 2 hour period previous to the start of the examination. A recording period of about 10-15 minutes was necessary before simultaneously a stable baseline $t c \mathrm{pO}_{2}$ value from the dorsum of the first metatarsophalangeal joint of the foot and a stable reference tcpO $\mathrm{O}_{2}$ value from the chest were obtained at rest. After detemining the reference tcpO $\mathrm{O}_{2}$ value at the chest, tcpO $\mathrm{O}_{2}$ monitoring at this site was stopped and the $t c \mathrm{pO}_{2}$ electrode was disconnected. Subsequently, all subjects were asked to inhale calmly $100 \%$ of oxygen through a mask, that was connected to an oxygen cylinder. Oxygen was supplied at a rate of 10 litres/min. About 10 minutes of oxygen inhalation were necessary to reach a maximum $t \mathrm{pO}_{2}$ value, which remained stable during further oxygen inhalation. After reaching this maximum $t \mathrm{pO}_{2}$ value, all subjects started to breathe ambient air again. When the $\mathrm{tcpO}_{2}$ at the foot had retumed to the baseline value at rest, perfusion of the foot was stopped by rapidly inflating to a suprasystolic level a $12 \mathrm{~cm}$ wide pneumatic cuff, wrapped around the ankle. Cuff pressure was kept at that level for up to 3-5 minutes, depending on the pain tolerance of the subject. Occlusion caused $\mathrm{tcpO}_{2}$ to decrease to about $0 \mathrm{~mm} \mathrm{Hg}$ in almost all subjects. Subsequently, the tcpO 2 response after rapidly deflating the cuff was recorded. The following parameters were derived from the readings:

\section{RESTING $\mathrm{TCPO}_{2}$, expressed in $\mathrm{mm} \mathrm{Hg}$.}

The stable baseline tcpO $\mathrm{O}_{2}$ value at rest, determined at an intact part of the skin at the dorsum of the first metatarsophalangeal joint of the foot, after a recording period of 10-15 minutes. RESTING $\mathrm{TCPO}_{2}$ reflects total skin blood flow at rest. 


\section{CHEST TCPO), expressed in mm Hy.}

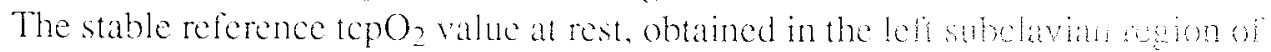
the chest, after a recording period of $1(0-15$ minutes.

\section{RATE TCPO2, expressed in mm Hg/min.}

The maximum rate of rise of $t \mathrm{cPO}_{2}$ at the foot during oxygen inhalation, usually occurring in the initial phase.

\section{PEAK TCPO2, expressed in $\mathrm{mm} \mathrm{Hg}$.}

The maximum tepO $\mathrm{O}_{2}$ value at the foot during oxygen inhalation.

\section{5. $\mathrm{T} 50 \% \mathrm{TCPO}$, expressed in seconds (s).}

The time needed to reach $50 \%$ of the RESTING TCPO 2 following the release of a transient arterial occlusion ( $3-5$ minutes). $\mathrm{T} 50 \% \mathrm{TCPO}_{2}$ indirectly provides information about the degree of arteriolar dilation at rest.

To investigate the influence of the change in posture on the results of $\mathrm{tcpO}_{2}$ monitoring, all measurements at the foot were subsequently repeated with the subjects in a comfortable sitting position with the legs dependent. These measurements were performed after an adaptation period of at least 15 minutes.

\section{Protocol of intravital skin capillary microscopy}

Following tc $\mathrm{PO}_{2}$ monitoring, subjects were seated with the legs dependent on a chair with hydraulically adjustable height to position the foot on the stage of the microscope. To obtain a stable image, the leg of interest was gently immobilized at knce level without obstructing blood flow to the foot. The forefoot itself was fixed in a mass of clay. In this position subjects rested for 15 minutes. Since red blood cell velocity at rest often varies rhythmically, images of capillaries were recorded for about 2 minutes (46). Capillary loops were recorded with the arteriolar limbs parallel to the video lines. After this 'period of rest', blood flow to the foot was arrested by inflating a pneumatic cuff (width $12 \mathrm{~cm}$ ), which was wrapped around the ankle, to a suprasystolic pressure. After a 1 minute occlusion, the cuff was rapidly deflated. The subsequent reactive hyperaemia images were stored on videotape. Images of 3 to 5 different capillaries, randomly chosen in the nailfold of the first toe, were recorded in this way. In 2 patients, however, images of capillaries at the dorsum of the first metatarsophalangeal joint of the foot were recorded since their first and second toe had been amputated. Red blood cell velocity was measured off-line with the use of the video flying spot method (47-49). Four spots, generated on the video screen and moving along the video lines, were synchronized with the moving red blood cells and plasma gaps. The following parameters were determined from the video images: 


\section{Red blood cell velocity at rest (RBCV), expressed in $\mathrm{mm} / \mathrm{s}$.}

Red blood cell velocity at rest was measured in 4 to 5 different periods of about 20 seconds during the "period of rest'and mean red blood cell velocity at rest was calculated for each capillary. Mean RBCV for that particular subject was obtained by averaging the mean red blood cell velocities at rest of 3 to 5 different capillaries.

\section{Peak red blood cell velocity (PRBCV), expressed in $\mathrm{mm} / \mathrm{s}$.}

By repetitively replaying the response following the release of a 1 minute arterial occlusion, the highest red blood cell velocity in the capillary under investigation was assessed with the use of the flying spot device. This velocity was regarded as peak red blood cell velocity for that particular capillary. Mean PR BCV of a subject was calculated by averaging the peak red blood cell velocities, determined in 3 to 5 capillaries.

\section{Red blood cell velocity index (RBCVI).}

By dividing the peak red blood cell velocity by the mean red blood cell velocity at rest of the same capillary, RBCVI of that specific capillary was calculated. Mean RBCVI for a subject was determined by averaging the different calculated red blood cell velocity indices, obtained from each of the capillaries examined.

\section{Time-to-peak red blood cell velocity (TTP), expressed in seconds (s).}

Time-to-peak red blood cell velocity is the time that elapsed between the release of the cuff and the moment of peak red blood cell velocity. Mcan TrTP for that subject was calculated by averaging the time-to-peaks of 3 to 5 investigated capillaries.

PRBCV, RBCVI and TTP have in common that they indirectly give information about the degree of arteriolar dilation at rest.

\section{Diameter of the arteriolar limb of the capillary loop (DIAMETER), expressed in $\mu \mathrm{m}$.}

The flying spot device was also used to measure from still images the diameters of the arteriolar limbs of the same capillary loops, in which the aforementioned parameters had been determined (Figure 4.1). A spot was positioned over the first visible part of the arteriolar limb of the capillary loop. By adjusting the width of the spot to the width of the capillary, the arteriolar limb diameter at that position was determined. A correction was made if the edges of spot and arteriolar limb were not exactly parallel. This procedure was repeated 2 to 3 times along the same arteriolar limb at equal intervals from the first measurement. The length of these intervals, which depended on the length of the arteriolar limb investigated, ranged 


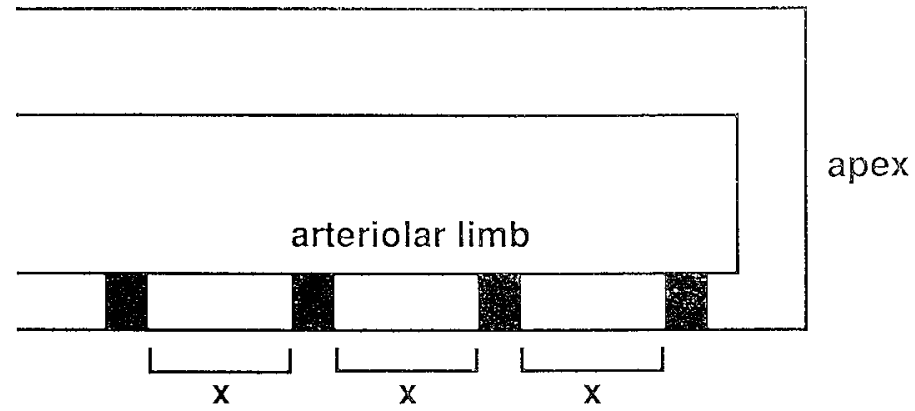

Figure 4.1 Drawing of a capillary loop with arteriolar and venular limb, and apex. Four spots are successively positioned over the arteriolar limb at equal intervals $(x)$ and adjusted to the width of the arteriolar limb.

from appproximately 11 to about $22 \mu \mathrm{m}$. The mean diameter of the arteriolar limb of that capillary was calculated as the mean of these measurements. Mean DIAMETER for a subject was obtained by averaging the mean diameters of all investigated capillaries.

\section{Density of toe nailfold capillaries (DENSITY), expressed in n (number) $/ \mathrm{mm}^{2}$.}

The number of capillary loops, identified as filled with red blood cells, was counted from still images on the full size of the TV monitor. At each count the apexes of the capillaries of the distal row were situated close to the right hand boundary of the monitor. In every subject at least 3 screens, each covering a different part of the same nailfold, were counted. The resulting mean number of capillary loops per screen was converted to a DENSITY value per $\mathrm{mm}^{2}$ by dividing it by the investigated skin surface area of $1.86 \mathrm{~mm}^{2}$.

\section{Nutritional skin blood flow at rest (NSBF), expressed in $\mathrm{mm}^{3} / \mathrm{s}$ per $\mathrm{mm}^{2}$ of the investigated skin surface area.}

The nutritional skin blood flow at rest per $\mathrm{mm}^{2}$ of the investigated skin surface area was calculated by multiplying the mean capillary blood flow at rest ( $\left.\mathrm{BF}_{\mathrm{cap}}\right)$ by the number of capillaries per $\mathrm{mm}^{2}$ (DENSITY). For each capillary investigated, $\mathrm{BF}_{\text {cap }}$ was calculated using the formula:

$$
\pi \cdot\left(\frac{D_{c a p}}{2}\right)^{2} \cdot V_{c a p}
$$


where Dcap is the mean diameter of the arteriolar limb of a capillary loop, expressed in mm, and Veap is the mean red blood cell velocity at rest of that same capillary, expressed in $\mathrm{mm} / \mathrm{s}$.

\subsection{RESULTS}

\subsubsection{Results of tcpO monitoring in the supine and sitting position}

\section{Supine position}

The median stable baseline $t \mathrm{cpO}_{2}$ at rest at the dorsum of the first metatarsophalangeal joint of the foot ( $\mathrm{RESTING} T \mathrm{TCPO}_{2}$ ) in subjects of the control-group was $57 \mathrm{~mm} \mathrm{Hg}$ (Figure 4.2). In patients of the F2-group the median RESTING $\mathrm{TCPO}_{2}$ was $46 \mathrm{~mm} \mathrm{Hg}$ and in patients of the F3/4-group $4 \mathrm{~mm} \mathrm{Hg}$. RESTING $\mathrm{TCPO}_{2}$ was significantly different between the 3 groups.

The median stable reference tcpO $\mathrm{O}_{2}$ at rest at the chest (CHEST TCPO2) was 63 mm Hg in the control-group, whereas in the $\mathrm{F}_{2}$-group the median $\mathrm{CHEST}_{\mathrm{TCPO}}$

\section{RESTING $\mathrm{TCPO}_{2}$ in $\mathrm{mm} \mathrm{Hg}$ (supine position)}

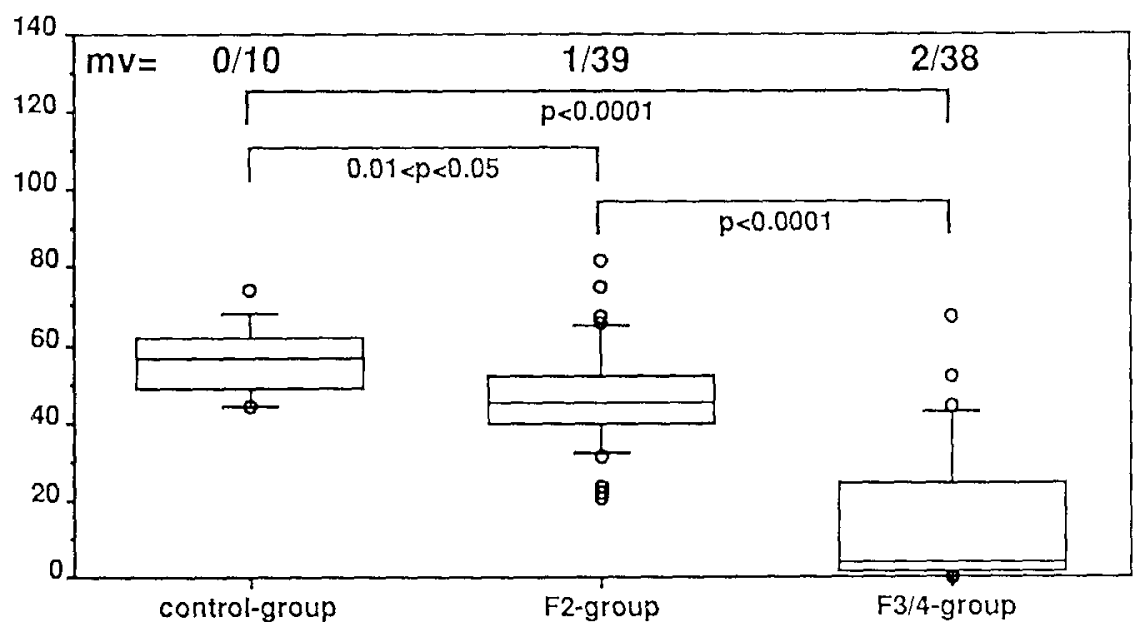

Figure 4.2 Stable baseline tcpO $\mathrm{O}_{2}$ at rest at the dorsum of the first metatarsophalangeal joint of the foot (RESTING TCPO2) in the supine position in healthy subjects (control-group) and in patients with various degrees of peripheral vascular disease according to Fontaine's classification (F2-group and F3/4-group), as shown by box plots; $m v=$ missing value(s). 
CHEST TCPO 2 in mm Ho (stipheposhion)

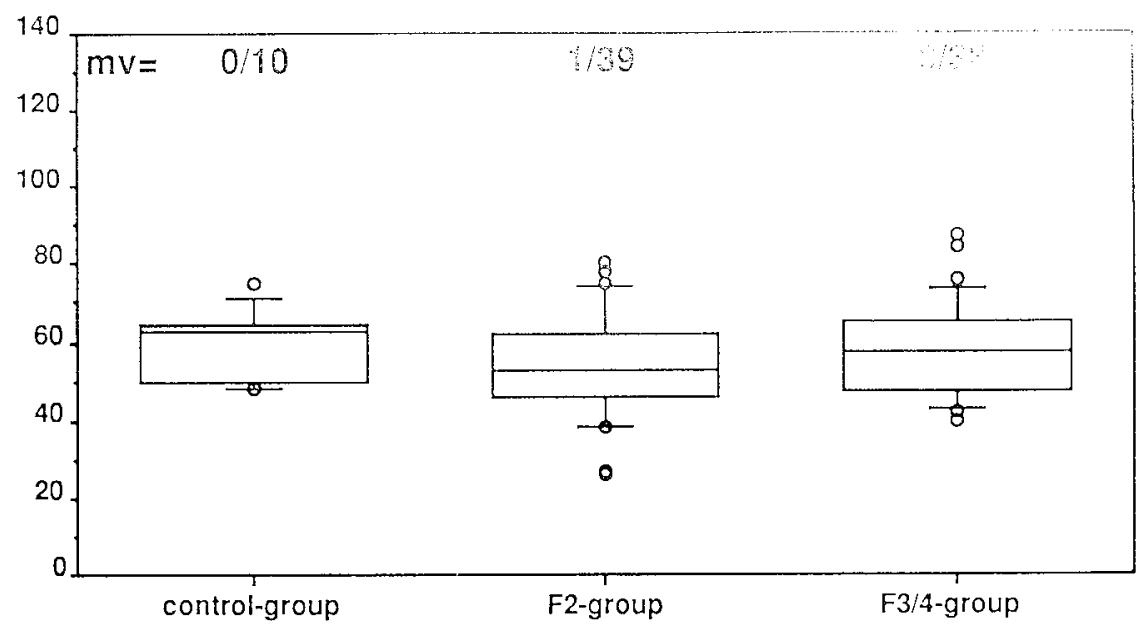

Figure 4.3 Stable reference tcpO $\mathrm{O}_{2}$ at rest at the chest (CHEST TCPO2) in the supine position in healthy subjects (control-group) and in patients with various degrees of peripheral vascular disease according to Fontaine's classification (F2-group and F3/4-group), as shown by box plots; $m v=$ missing value(s).

\section{RATE $\mathrm{TCPO}_{2}$ in $\mathrm{mm} \mathrm{Hg} / \mathrm{min}$ (supine position)}

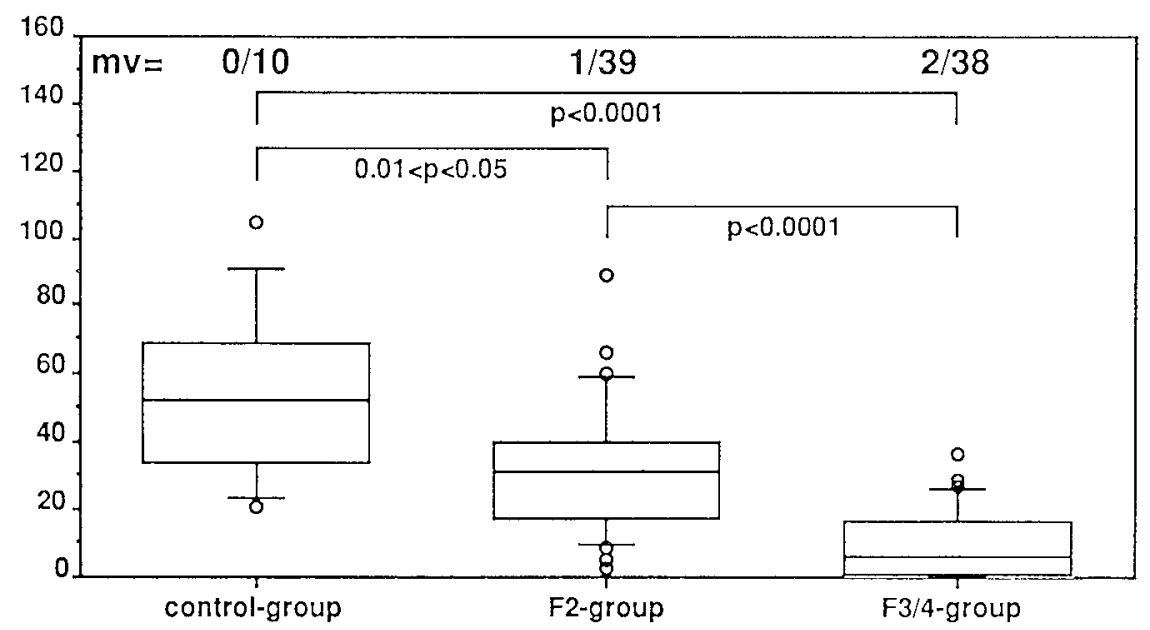

Figure 4.4 Maximum rate of rise of tcpO $\mathrm{pO}_{2}$ at the dorsum of the first metatarsophalangeal joint of the foot during oxygen inhalation ( $\mathrm{RATE} \mathrm{TCPO}_{2}$ ) in the supine position in healthy subjects (control-group) and in patients with various degrees of peripheral vascular clisease according to Fontaine's classification (F2-group and F3/4-group), as shown by box plots; mv = missing value(s). 


\section{$\mathrm{PEAK} \mathrm{TCPO}_{2}$ in $\mathrm{mm} \mathrm{Hg}$ (supine position)}

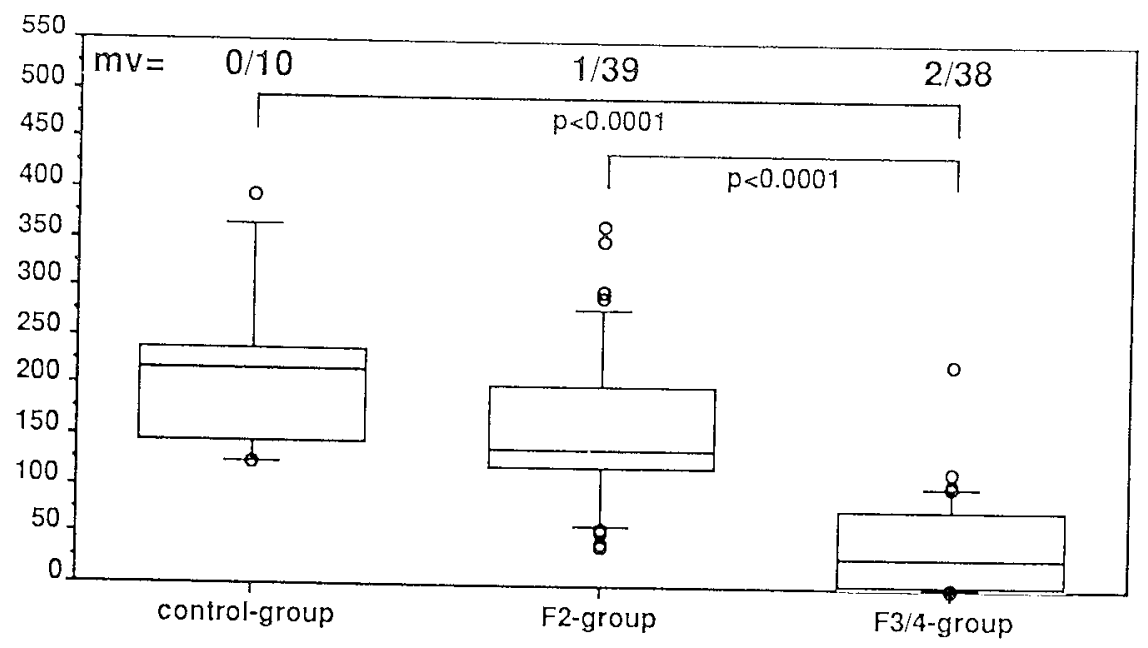

Figure 4.5 Maximum level of tep $\mathrm{O}_{2}$ at the dorsum of the first metatarsophalangeal joint of the foot during oxygen inhalation (PEAK TCPO2) in the supine position in healthy subjects (controlgroup) and in patients with various degrees of peripheral valscular discase according to Fontaine's classification (F2-group) and F3/4-group), as shown by box plots; mv = missing value(s).

was $53 \mathrm{~mm} \mathrm{Hg}$ (Figure 4.3). The F3/4-group had a median CHEST TCPO2 of 57 $\mathrm{mm} \mathrm{Hg}$. CHEST $\mathrm{TCPO}_{2}$ did not differ significantly between the 3 groups.

During oxygen inhalation the median maximum rate of rise of $\mathrm{tcpO}_{2}$ at the dorsum of the first metatarsophalangeal joint of the foot (RATE TCPO 2 ) was 52 $\mathrm{mm} \mathrm{Hg} / \mathrm{min}, 32 \mathrm{~mm} \mathrm{Hg} / \mathrm{min}$ and $7 \mathrm{~mm} \mathrm{Hg} / \mathrm{min}$ in the control-group, the F2-group and the F3/4-group, respectively (Figure 4.4). An increase in the severity of lower limb ischaemia was associated with a significant decrease in $\mathrm{RATE} \mathrm{TCPO}_{2}$.

The maximum level of $\mathrm{tcpO}_{2}$ at the dorsum of the first metatarsophalangeal joint of the foot during oxygen inhalation $\left(\mathrm{PEAK} \mathrm{TCPO}_{2}\right)$ had a median value of $217 \mathrm{~mm} \mathrm{Hg}$ in subjects of the control-group, while patients of the F2-group and the F3/4-group had a median PEAK TCPO2 of $138 \mathrm{~mm} \mathrm{Hg}$ and $30 \mathrm{~mm} \mathrm{Hg}$, respectively (Figure 4.5). PEAK TCPO 2 in the $\mathrm{F} 3 / 4$-group was significantly lower than in the control-group and the F2-group.

The median time needed to reach $50 \%$ of the RESTING $\mathrm{TCPO}_{2}$ at the dorsum of the first metatarsophalangeal joint of the foot following the release of a transient arterial occlusion $\left(\mathrm{T}_{50} \% \mathrm{TCPO}_{2}\right.$ ) was $45 \mathrm{~s}$ in the control-group (Figure 4.6). The median $\mathrm{T}_{50} \% \mathrm{TCPO}_{2}$ in patients of the $\mathrm{F} 2$-group and the $\mathrm{F} 3 / 4$-group was $72 \mathrm{~s}$ and $114 \mathrm{~s}$, respectively. $\mathrm{T} 50 \% \mathrm{TCPO}_{2}$ was significantly prolonged with increasing severity of peripheral vascular disease. 
$\mathrm{T} 50 \% \mathrm{TCPO}_{2}$ in s (supine position)

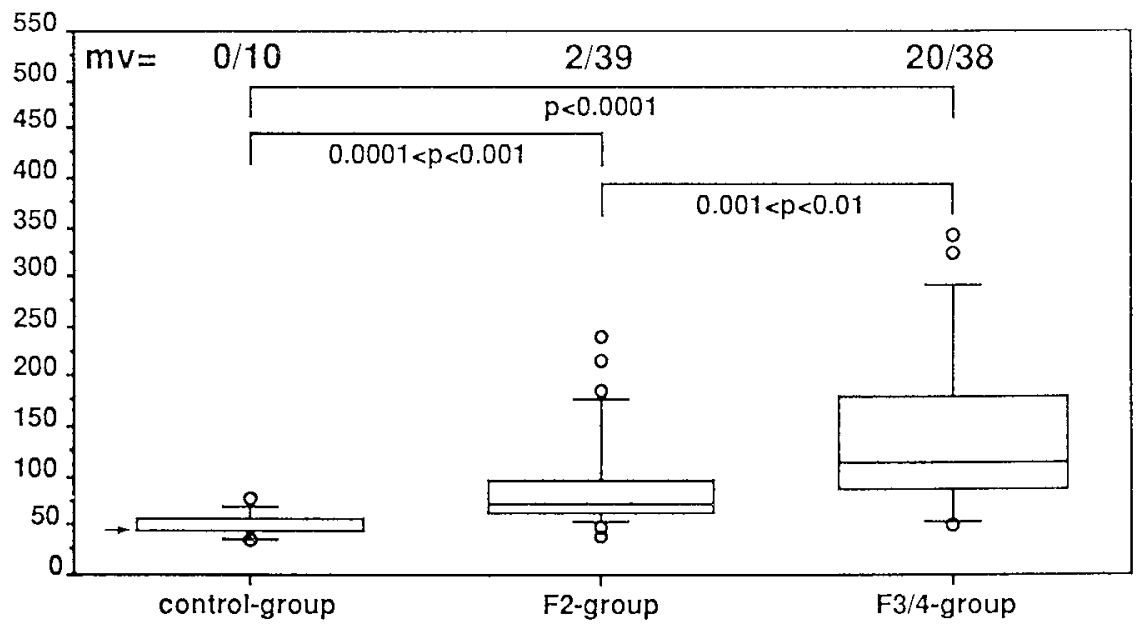

Figure 4.6 Time needed to reach $50 \%$ of the RESTING TCPO2 at the dorsum of the first metatarsophalangeal joint of the foot following the release of a transient arterial occlusion (T50\% $\mathrm{TCPO}_{2}$ ) in the supine position in healthy subjects (control-group) and in patients with various degrees of peripheral vascular disease according to Fontaine's classification (F2-group and F3/4-group), as shown by box plots; $m v=$ missing value(s); $\rightarrow=$ median value.

\section{RESTING $\mathrm{TCPO}_{2}$ in $\mathrm{mm} \mathrm{Hg}$ (sitting position)}

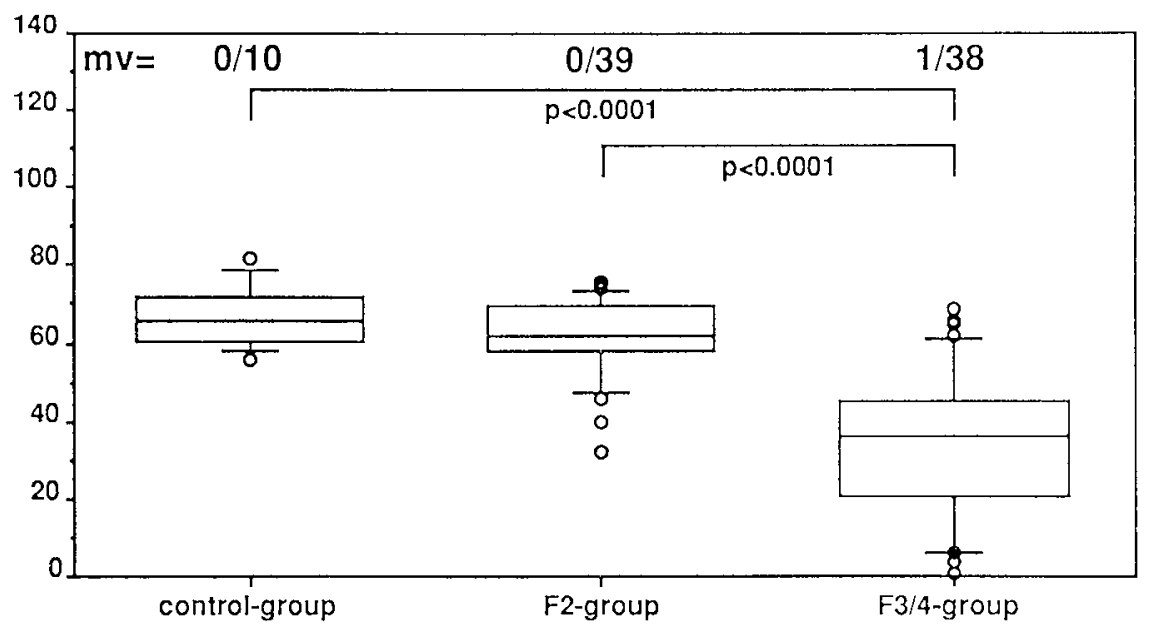

Figure 4.7 Stable baseline tcpO at rest at the dorsum of the first metatarsophalangeal joint of the foot (RESTING $\mathrm{TCPO}_{2}$ ) in the sitting position in healthy subjects (control-group) and in patients with various degrees of peripheral vascular disease according to Fontaine's classification (F2-group and F3/4-group), as shown by box plots; $m v=$ missing value(s). 
RATE $\mathrm{TCPO}_{2}$ in $\mathrm{mm} \mathrm{Hg} / \mathrm{min}$ (sitting position)

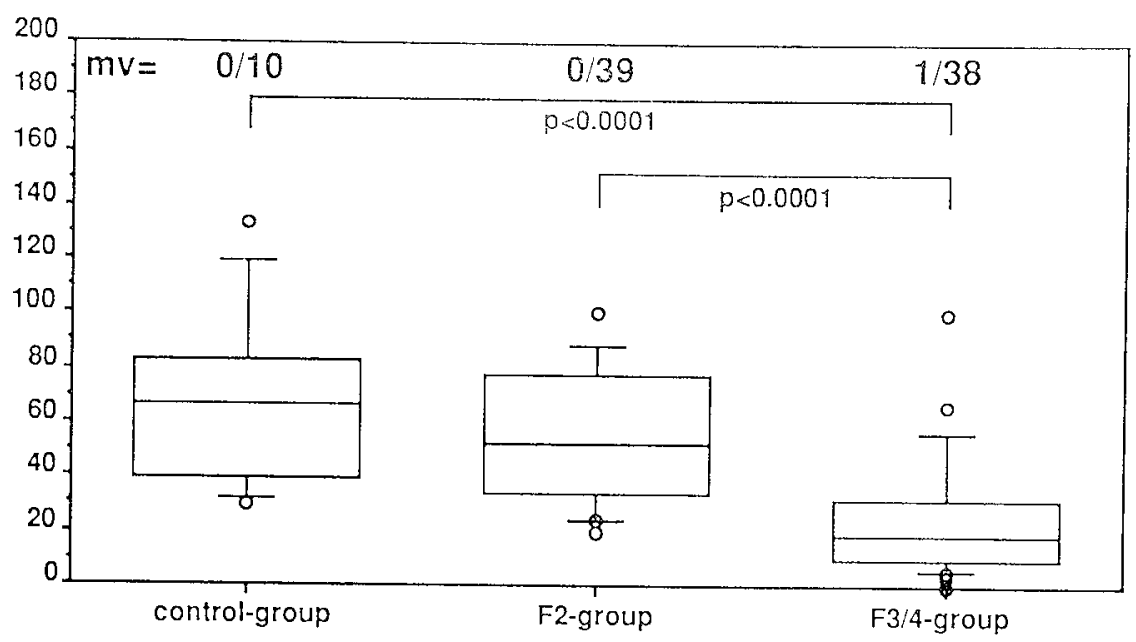

Figure 4.8 Maximum rate of rise of $\mathrm{tepO}_{2}$ at the dorsum of the first metatarsophalangeal joint of the foot during oxygen inhalation (RATE TCPO2) in the sitting position in healthy subjects (control-group) and in patients with various degrees of peripheral vascular disease according to Fontaine's classification (F2-group and F3/4-group), as shown by box plots; mv = missing value(s).

\section{Sitting position}

The median stable baseline $\mathrm{tcpO}_{2}$ at rest at the dorsum of the first metatarsophalangeal joint of the foot (RESTING TCPO 2 ) in subjects of the control-group, the F2-group and the F3/4-group was $66 \mathrm{~mm} \mathrm{Hg}, 62 \mathrm{~mm} \mathrm{Hg}$ and $36 \mathrm{~mm} \mathrm{Hg}$, respectively (Figure 4.7). Patients of the F3/4-group had a significantly lower RESTING $\mathrm{TCPO}_{2}$, as compared to subjects of the control-group and the F2-group.

During oxygen inhalation the median value of the maximum rate of rise of $\mathrm{tcpO}_{2}$ at the dorsum of the first metatarsophalangeal joint of the foot (RATE $\mathrm{TCPO}_{2}$ ) was $67 \mathrm{~mm} \mathrm{Hg} / \mathrm{min}$ in the control-group (Figure 4.8). Patients of the F2-group had a median RATE $\mathrm{TCPO}_{2}$ of $53 \mathrm{~mm} \mathrm{Hg} / \mathrm{min}$, while patients of the F3/4-group had a median RATE TCPO 2 of $19 \mathrm{~mm} \mathrm{Hg} / \mathrm{min}$. A significant difference in RATE TCPO 2 was only present between the F3/4-group on the one hand and the control-group and the F2-group on the other.

The maximum level of $\mathrm{TCPO}_{2}$ at the dorsum of the first metatarsophalangeal joint of the foot during oxygen inhalation ( $\mathrm{PEAK} \mathrm{TCPO}_{2}$ ) had a median value of $230 \mathrm{~mm} \mathrm{Hg}, 199 \mathrm{~mm} \mathrm{Hg}$ and $81 \mathrm{~mm} \mathrm{Hg}$ in subjects of the control-group, the F2-group and the F3/4-group, respectively (Figure 4.9). PEAK $\mathrm{TCPO}_{2}$ of the 
PEAK TCPO 2 in $\mathrm{mm} \mathrm{Mg}$ (sitting position)

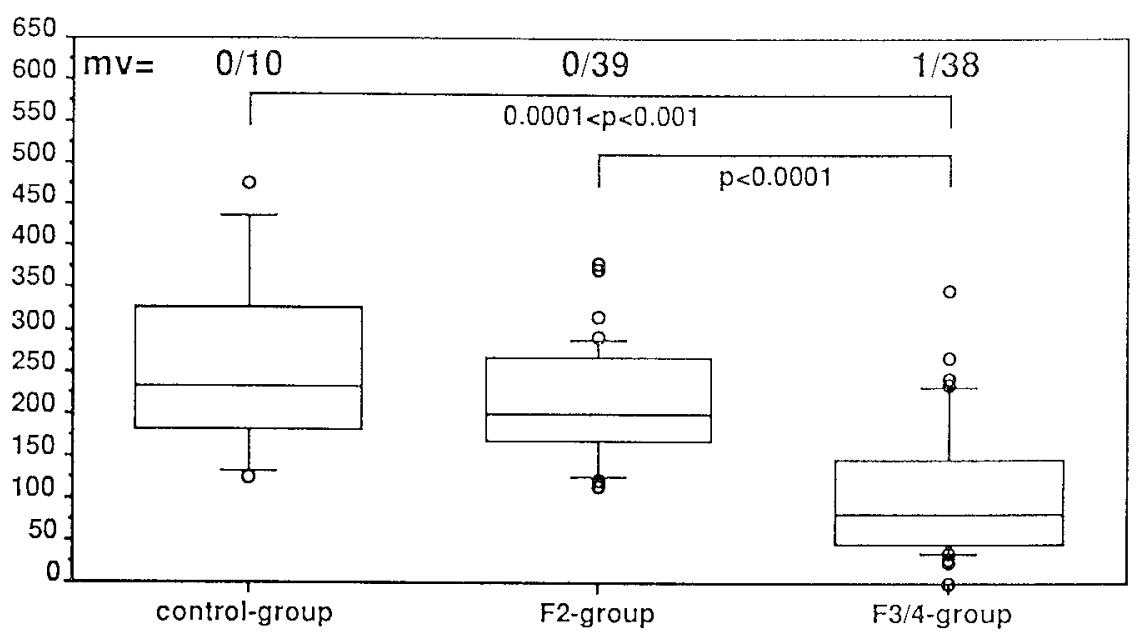

Figure 4.9 Miximum level of tepO2 at the dorsum of the first metatarsophalangeal joint of the foot during oxygen inhalation ( $\mathrm{PEAK} \mathrm{TCPO}$ ) in the sitting position in healthy subjects (controlgroup) and in patients with various degrees of peripheral vascular disease according to Fontaine's classification (F2-group and F3/4-group), as shown by box plots; $m v=$ missing value(s).

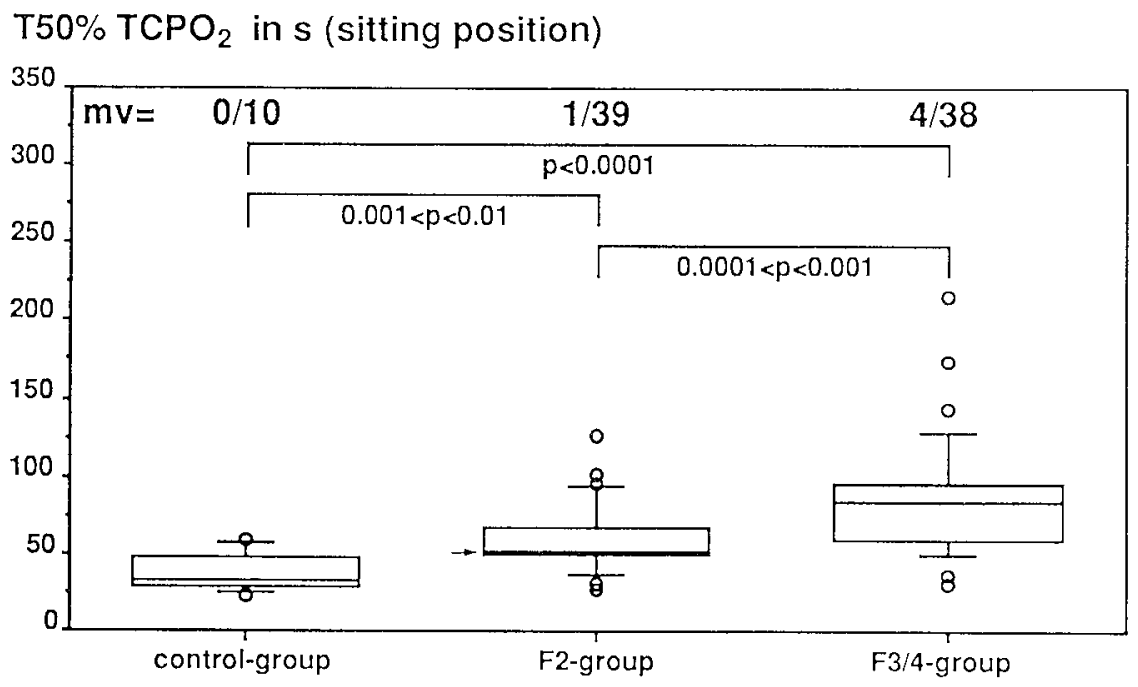

Figure 4.10 Time necessary to regain $50 \%$ of the RESTING $\mathrm{TCPO}_{2}$ at the dorsum of the first metatarsophalangeal joint of the foot following the release of a transient arterial occlusion (T50\% $\mathrm{TCPO}_{2}$ ) in the sitting position in healthy subjects (control-group) and in patients with various degrees of peripheral vascular disease according to Fontaine's classification (F2-group and F3/4-group), as shown by box plots; $m v=$ missing value(s); $\rightarrow=$ median value. 
F3/4-group was significantly lower, as compared to the control-group and the F2-group.

The median time necessary to regain $50 \%$ of the RESTING $\mathrm{TCPO}_{2}$ at the dorsum of the first metatarsophalangeal joint of the foot following the release of a transient arterial occlusion ( $\mathrm{T} 50 \% \mathrm{TCPO} \mathrm{T}_{2}$ ) was $32 \mathrm{~s}, 51 \mathrm{~s}$ and $84 \mathrm{~s}$ in the controlgroup, the F2-group and the F3/4-group, respectively (Figure 4.10). Progression of peripheral vascular disease was associated with a significantly prolonged $550 \%$ $\mathrm{TCPO}_{2}$.

As shown in Table 4.1, changing from the supine to the sitting position resulted in a significant improvement in RESTING $\mathrm{TCPO}_{2}, \mathrm{RATE} \mathrm{TCPO}_{2}$ and $\mathrm{T} 50 \% \mathrm{TCPO}_{2}$ in all 3 groups investigated. PEAK TCPO2, however, was only significantly increased in the F2-group and the F3/4-group.

Table 4.1 Influence of posture (supine versus sitting) on tepO2 parameters at the foot. Median values are presented.

\begin{tabular}{|c|c|c|c|}
\hline & CONTROL & $\mathrm{F} 2$ & $F 3 / 4$ \\
\hline \multirow[t]{2}{*}{ RESTING TCPO2 supine $(\mathrm{mm} \mathrm{Hg})$} & 57 & 46 & 4 \\
\hline & ** & $* \cdots$ & $\star \star \star \star *$ \\
\hline RESTING TCPO2 sitting $(\mathrm{mm} \mathrm{Hg})$ & 66 & 62 & 36 \\
\hline \multirow[t]{2}{*}{ RATE TCPO 2 supine $(\mathrm{mm} \mathrm{Hg} / \mathrm{min})$} & 52 & 32 & 7 \\
\hline & * & $* * * *$ & $\star * * *$ \\
\hline RATE TCPO 2 sitting $(\mathrm{mm} \mathrm{Hg} / \mathrm{min})$ & 67 & 53 & 19 \\
\hline \multirow[t]{2}{*}{ PEAK TCPO2 supine $(\mathrm{mm} \mathrm{Hg})$} & 217 & 138 & 30 \\
\hline & ns & $* * * \star$ & $* \star * \star$ \\
\hline PEAK TCPO2 sitting $(\mathrm{mm} \mathrm{Hg})$ & 230 & 199 & 81 \\
\hline \multirow[t]{2}{*}{ T50\% TCPO2 supine (s) } & 45 & 72 & 114 \\
\hline & ** & $* * * \star$ & $\star \star$ \\
\hline T50\% TCPO 2 sitting (s) & 32 & 51 & 84 \\
\hline
\end{tabular}

RESTING TCPO $2=$ stable baseline $\mathrm{TCPO}_{2}$ at rest at the foot, $\mathrm{RATE} \mathrm{TCPO}_{2}=$ maximum rate of rise of $\mathrm{TCPO}_{2}$ at the foot during oxygen inhalation, $\mathrm{PEAK} \mathrm{TCPO}_{2}=$ maximum level of $\mathrm{tcpO}_{2}$ at the foot during oxygen inhalation, $\mathrm{T} 50 \% \mathrm{TCPO} 2=$ time needed to reach $50 \%$ of the RESTING $\mathrm{TCPO}_{2}$ at the foot following the release of a transient arterial occlusion; CONTROL $=$ control-group, F2 $=$ F2-group, F3/4 = F3/4-group; Levels of significance: ${ }^{\star}=0.01<\mathrm{p}<0.05,{ }^{\star \star}=0.001<\mathrm{p}<0.01$, ${ }^{\star \star \star}=0.0001<\mathrm{p}<0.001,{ }^{\star \star \star \star}=\mathrm{p}<0.0001, \mathrm{~ns}=$ not significant. 
$\mathrm{RBCV}$ in $\mathrm{mm} / \mathrm{s}$ (sititing positica:

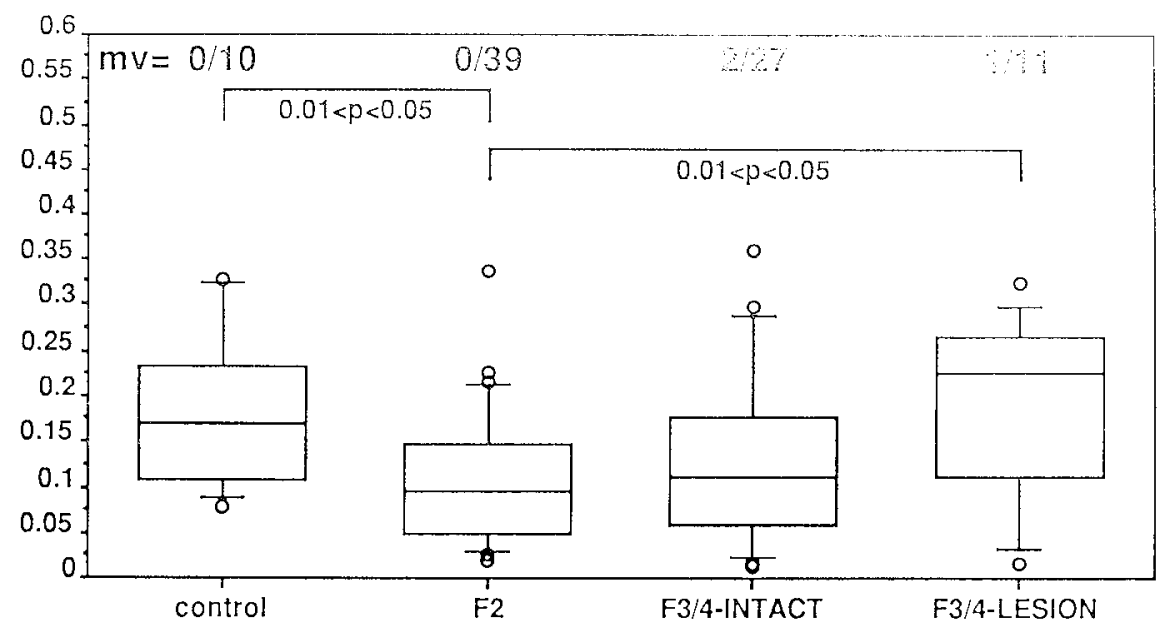

Figure 4.11 Red blood cel! velocity at rest (RBCV) in the sitting position in healthy subjects (control = control-group) and in patients with various degrees of peripheral vascular disease according to Fontaine's classification (F2 = F2-group, F3/4-INTACT = F3/4-INTACT-group and F3/4-LESION = F3/4-LESION-group), as shown by box plots; $m v=$ missing value(s).

\section{PRBCV in $\mathrm{mm} / \mathrm{s}$ (sitting position)}

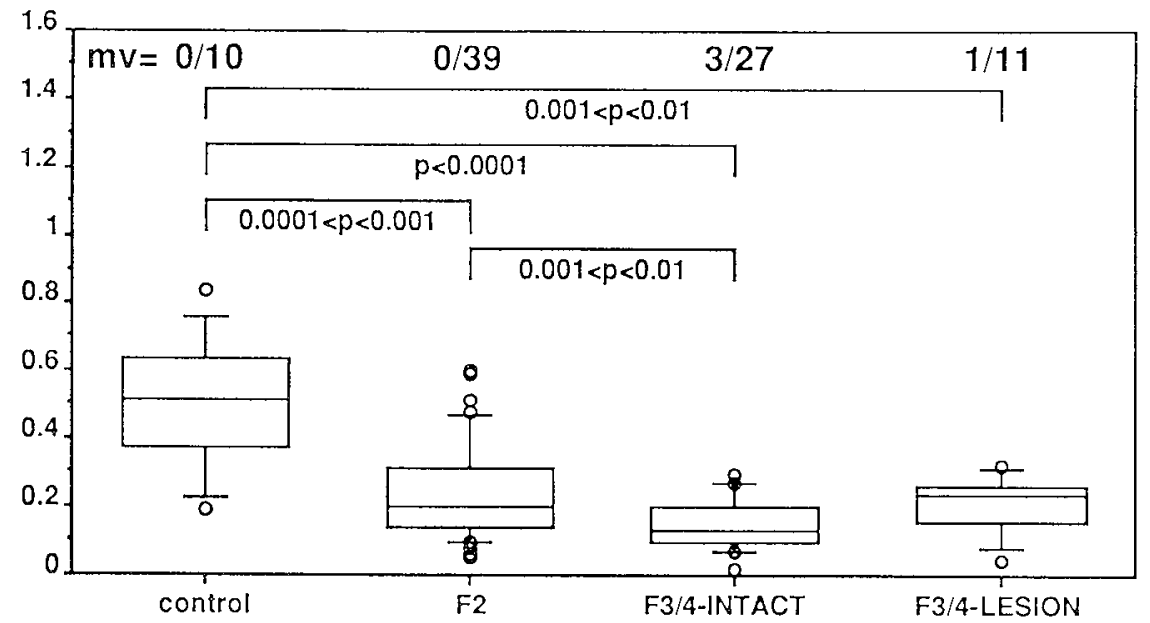

Figure 4.12 Peak red blood cell velocity following the release of a transient arterial occlusion ( $\mathrm{PRBCV}$ ) in the sitting position in healthy subjects (control = control-group) and in patients with various degrees of peripheral vascular disease according to Fontaine's classification (F2 = F2-group, F3/4-INTACT = F3/4-INTACT-group and F3/4-LESION = F3/4 LESION-group), as shown by box plots; mv = missing value(s). 


\section{RBCVI (sitting position)}

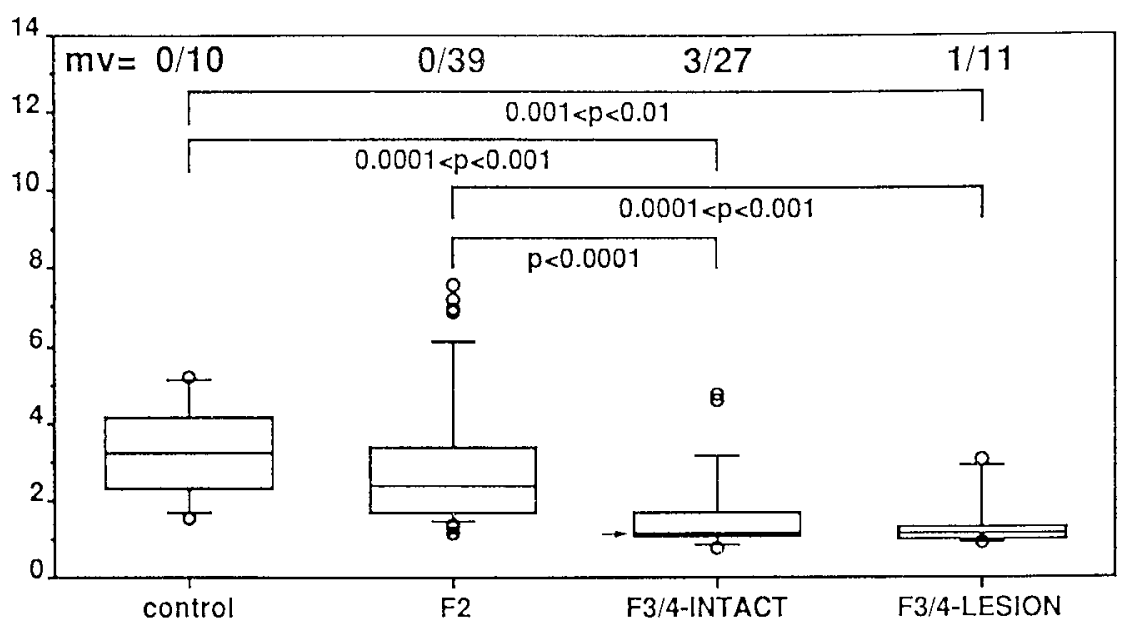

Figure 4.13 Ratio of PRBCV to RBCV (RBCVI (red blood cell velocity index)) in the sitting position in healthy subjects (control = control-group) and in patients with various degrees of peripheral vascular disease according to Fontaine's classification (F2 = F2-group, F3/4-INTACT $=$ F3/4-INTACT-group and F3/4-LESION = F3/4-LESION-group), as shown by box plots; $m v=$ missing value $(\mathrm{s}) ; \rightarrow=$ median value.

\subsubsection{Results of intravital skin capillary microscopy in the sitting position}

The median red blood cell velocity at rest (RBCV) in the control-group was 0.171 $\mathrm{mm} / \mathrm{s}$ and in patients of the F2-group $0.095 \mathrm{~mm} / \mathrm{s}$ (Figure 4.11). Patients of the F3/4-INTACT-group, of whom an intact part of the skin was investigated, had a median RBCV of $0.110 \mathrm{~mm} / \mathrm{s}$. In patients of the F3/4-LESION-group, on whom intravital skin capillary microscopy was performed in the rim of an ischaemic skin lesion, a median RBCV of $0.227 \mathrm{~mm} / \mathrm{s}$ was found. RBCV of the F2-group was significantly lower, as compared to the control-group and the F3/4-LESIONgroup.

The median peak red blood cell velocity following the release of a transient arterial occlusion (PRBCV) was $0.519 \mathrm{~mm} / \mathrm{s}$ and $0.205 \mathrm{~mm} / \mathrm{s}$ in the control-group and the F2-group, respectively (Figure 4.12). In patients of the F3/4-INTACTgroup and the F3/4-LESION-group (rim of ischaemic skin lesion) the median PRBCV was $0.128 \mathrm{~mm} / \mathrm{s}$ and $0.237 \mathrm{~mm} / \mathrm{s}$, respectively. A significantly lower PRBCV was found in patients with peripheral vascular disease, as compared to healthy subjects. 


\section{TTP in s (sitting position)}

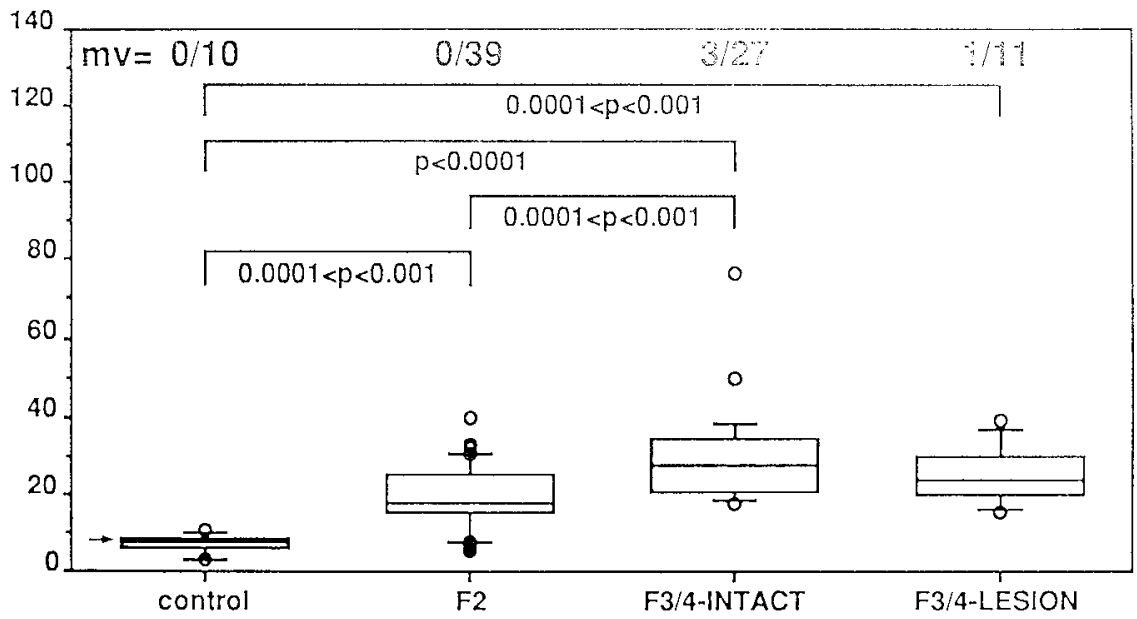

Figure 4.14 Time-to-peak red blood cell velocity following the release of a transient arterial occlusion (TIP) in the sitting position in healthy subjects (control = control-group) and in patients with various degrees of peripheral vascular disease according to Fontaine's classification (F2 = F2-group, F3/4-INTACT = F3/4-INTACT-group and F3/4-L ESION = F3/4-L ESION-group), as shown by box plots; mv = missing value(s); $\rightarrow=$ median value.

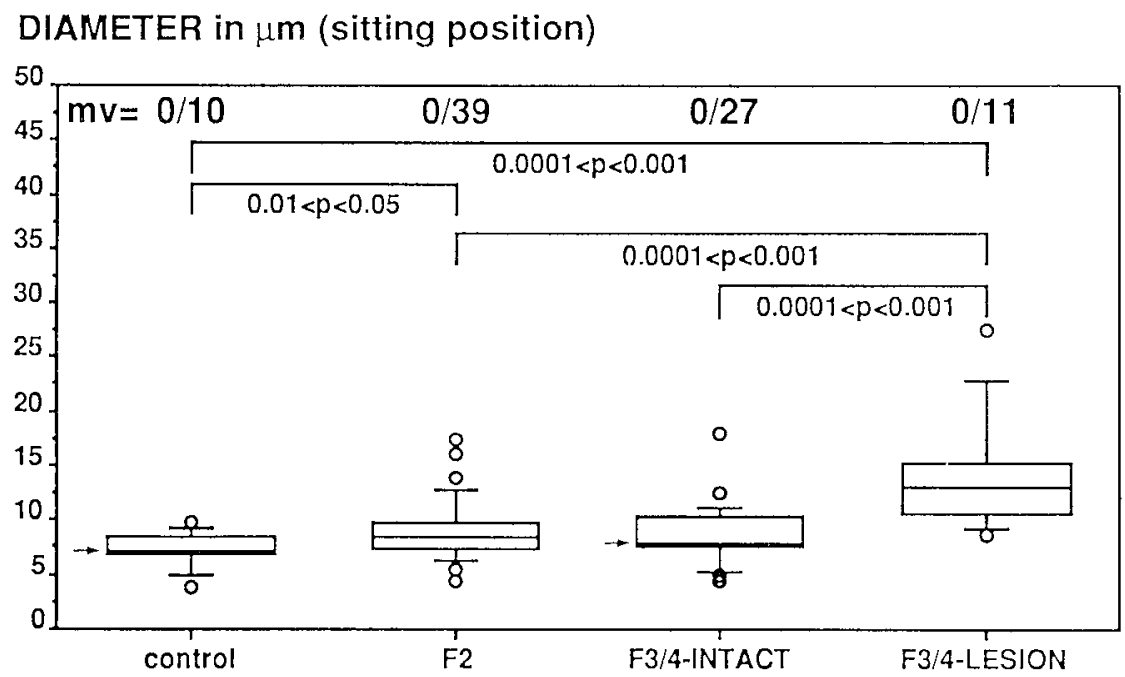

Figure 4.15 Diameter of the arteriolar limbs of capillary loops (DIAMETER) in the sitting position in healthy subjects (control $=$ control-group) and in patients with various degrees of peripheral vascular disease according to Fontaine's classification (F2 = F2-group, F3/4-INTACT $=$ F3/4-INTACT-group and F3/4-LESION = F3/4-LESION-group), as shown by box plots; $\mathrm{mv}=$ missing value $(\mathrm{s}) ; \rightarrow=$ median value. 


\section{DENSITY in n/mm ${ }^{2}$ (siting position)}

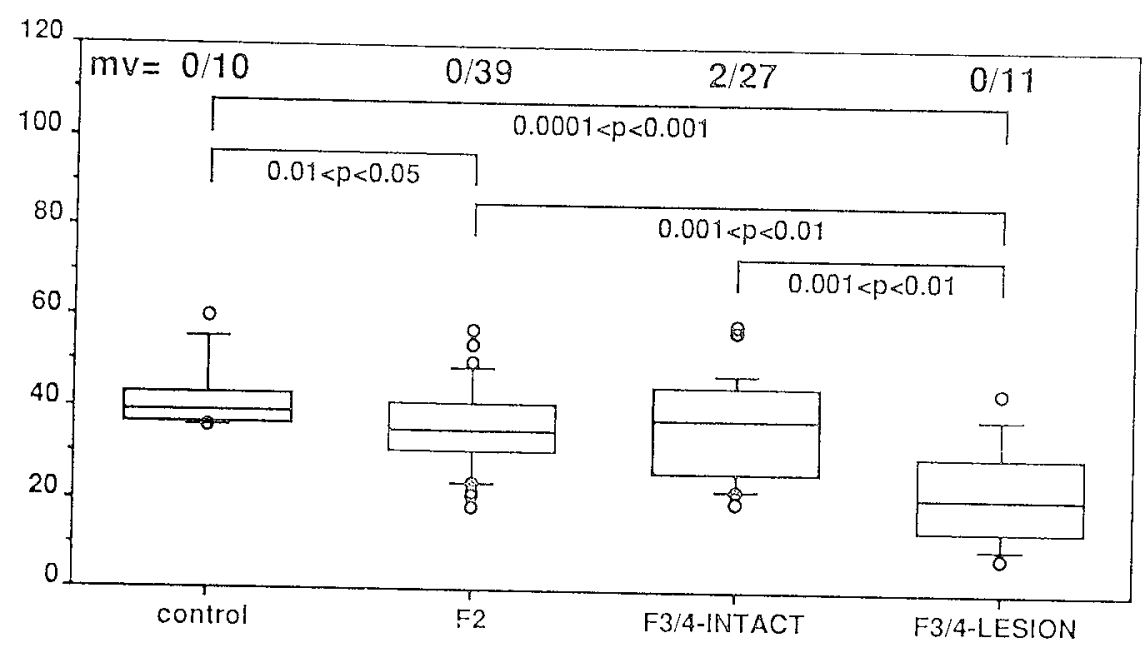

Figure 4.16 Number of blood-filled capillaries per $\mathrm{mm}^{2}$ of the investigated skin surface areat (DENSITY) in the sitting position in healthy subjects (control = control-group) and in patients with various degrees of peripheral vascular disease according to Fontaine's classification (F2 = F2-group, F3/4-INTACT =F3/4-INTACT-group and F3/4-LESION = F3/4-LESION-group), as shown by box plots; mv = missing value $(s)$.

The median ratio of PRBCV to RBCV (RBCVI (red blood cell velocity index)) was 3.24 in the control-group, 2.42 in the F2-group, 1.17 in the F3/4-INTACTgroup and 1.18 in the F3/4-LESION-group (rim of ischaemic skin lesion) (Figure 4.13). The RBCVI of the F3/4-INTACT-group and the F3/4-LESION-group were similar and both significantly lower, as compared to the control-group and the F2-group.

The median time-to-peak red blood cell velocity following the release of a transient arterial occlusion (TTP) was $8 \mathrm{~s}$ and $17 \mathrm{~s}$ in the control-group and the F2-group, respectively (Figure 4.14). In patients of the F3/4-INTACT-group and the F3/4-LESION-group (rim of ischaemic skin lesion) the median TTP was $28 \mathrm{~s}$ and $24 \mathrm{~s}$, respectively. Patients with peripheral vascular disease had a significantly prolonged TTP, as compared to healthy subjects.

The median diameter of the arteriolar limbs of capillary loops (DIAMETER) of the control-group was $7 \mu \mathrm{m}$, while in the F2-group a median DIAMETER of $9 \mu \mathrm{m}$ was found (Figure 4.15). The F3/4-INTACT-group had a median DIAMETER of 8 $\mu \mathrm{m}$. In the F3/4-LESION-group (rim of ischaemic skin lesion) the median DIAMETER was $13 \mu \mathrm{m}$. The DIAMETER was significantly larger in rims of ischaemic skin lesions (F3/4-LESION-group), as compared to intact parts of the skin in patients with equally severe peripheral vascular disease (F3/4-INTACT-group). 
NSBF $\times 10^{-3} \mathrm{in} \mathrm{mm}^{3} / \mathrm{s}$ (siming posm.

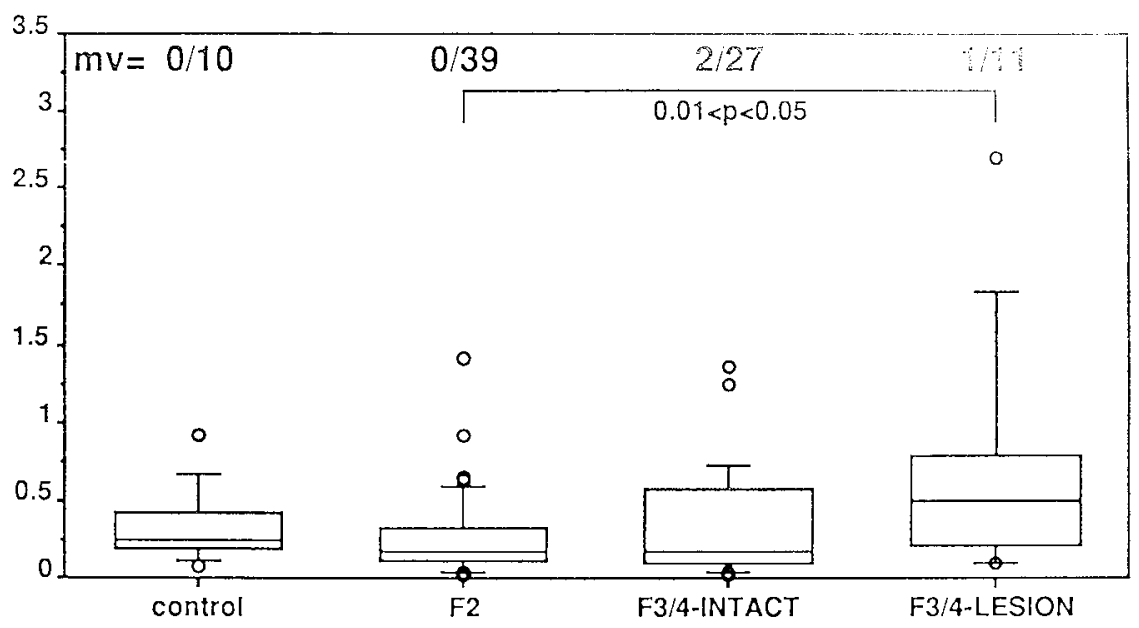

Figure 4.17 Nutritional skin blood flow at rest per $m^{2}$ of the investigated skin surface area (NSBF) in the sitting position in healthy subjects (control = control-group) and in patients with various degrees of peripheral vascular disease according to Fontaine's classification (F2 = F2-group, F3/4-INTACT $=$ F3/4-INTACT-group and F3/4-LESION $=$ F3/4-LESION-group), as shown by box plots; $m v=$ missing value $(\mathrm{s})$.

The median number of blood-filled capillaries per $\mathrm{mm} 2$ of the investigated skin surface area (DENSITY) was $39 / \mathrm{mm}^{2}$ in the control-group and $35 / \mathrm{mm}^{2}$ in the F2group (Figure 4.16). In the F3/4-INTACT-group the median DENSITY was $38 / \mathrm{mm}^{2}$ and in the F3/4-LESION-group (rim of ischaemic skin lesion) $21 / \mathrm{mm}^{2}$. Patients of the F3/4-LESION-group had a significantly lower DENSITY, as compared to healthy subjects, patients of the F2-group and patients of the F3/4-INTACT-group.

The median nutritional skin blood flow at rest per $\mathrm{mm}^{2}$ of the investigated skin surface area (NSBF) was $0.252 \cdot 10^{-3} \mathrm{~mm}^{3} / \mathrm{s}$ in subjects of the control-group (Figure 4.17). Patients of the F2-group and the F3/4-INTACT-group had a median NSBF of $0.176 \cdot 10^{-3} \mathrm{~mm}^{3} / \mathrm{s}$ and $0.166 \cdot 10^{-3} \mathrm{~mm}^{3} / \mathrm{s}$, respectively. In patients of the F3/4-LESION-group (rim of ischaemic skin lesion) the median NSBF was 0.490 $.10^{-3} \mathrm{~mm}^{3} / \mathrm{s}$. The NSBF of the F3/4-LESION-group did not differ significantly from the NSBF of the F3/4-INTACT-group despite a markedly higher median NSBF.

\subsection{DISCUSSION}

In the supine position skin oxygen delivery at rest, which reflects total skin blood flow at rest, is slightly decreased in patients with moderate peripheral vascular 
disease (intemittent claudicarion), as compared to healthy subjects. In patients with severe peripheral vascular discase (rest pain, ischacmic skin lesion(s)), however, oxygen supply to the skin at rest and hence total skin blood flow at rest is significantly impaired, as compared to both healthy subjects and patients with moderate peripheral vascular disease. The absence of a statistically significant difference in skin oxygen delivery at rest at the chest between the 3 groups excludes a contribution of ventilation or haemoglobin properties to the observed differences in peripheral skin oxygen supply. Furthermore, the inhalation of $100 \%$ of oxygen causes a proportional increase in skin oxygen delivery in the 3 groups investigated, preserving the aforementioned differences. It emphasizes that in patients with various degrees of lower limb ischaemia the perfusion is the limiting factor as far as peripheral oxygen supply to the skin is concerned. The response to the release of a transient arterial occlusion provides a far better separation between healthy subjects and patients with moderate peripheral vascular disease, as compared to the skin oxygen delivery at rest and during oxygen inhalation. This is in accordance with the findings of other investigators $(14,50,51)$.

Changing from the supine to the sitting position with the legs dependent leads to a moderate but unexpected increase in skin oxygen delivery at rest in healthy subjects and patients with moderate peripheral vascular disease, abolishing the small difference in total skin blood flow at rest between both groups. This increase in total skin blood flow at rest can probably be explained by the absence of vasoconstrictive mechanisms, caused by heating the skin (52-55). Under normal conditions these vasoconstrictive mechanisms cause a reduction in lower limb blood supply upon leg dependency in healthy subjects and patients with moderate peripheral vascular disease (52-54,56-59). Although a considerable improvement in total skin blood flow at rest upon changing from the supine to the sitting position is seen in patients with severe lower limb ischaemia, it still differs significantly from healthy subjects and patients with moderate peripheral vascular disease.

Investigation of the nutritional skin microcirculation shows that in patients with severe peripheral vascular disease the nutritional skin blood flow at rest in the intact skin is maintained at a normal level. The increase in red blood cell velocity following the release of a transient arterial occlusion in these patients, however, is reduced to a minimum, indicating the dilation of the arterioles at rest to be almost at the maximum. This considerable dilation at the arteriolar level may probably be regarded as a precapillary adjustment to increase nutritional skin blood flow at rest. Since in the intact skin of patients with severe peripheral vascular disease arteriolar dilation at rest is almost at the maximum, a further increase in ischaemia, due to progression of the disease and/or external skin compression, for example, caused by pinching shoes, may result in a crucial 
reduction in the number of blood-filled capillaries and hence the surface area for nutrition. This, finally, may cause the development of ischaemic skin lesions.

Examination of the nutritional skin microcirculation in the rims of ischacmic skin lesions, which indicate a more disturbed nutritional skin microcirculation, indeed reveals a significantly smaller number of capillaries, as compared to patients with the same degree of peripheral vascular discase, of whom intact skin parts are investigated microscopically. Despite this small number of capillaries, nutritional skin blood flow at rest in the rims of ischaemic skin lesions is similar to the nutritional skin blood flow at rest in the inact skin. This is likely to be due to the significant increase in the diameter of the anteriolar limbs of capillary loops, probably in response to metabolites released from these damaged skin parts. This increase in capillary diameter in the rims of ischaemic skin lesions may be regarded as an ultimate possibility to increase nutritional skin blood flow at rest in response to a further increase in local ischaemia. The morphological changes, dilation of capillaries and diminished capillary density, as observed in the rims of ischaemic skin lesions, are in accordance with the findings of Fagrell (24).

Investigations with the use of intravital skin capillary microscopy also show that the response to the relcase of a transient arterial occlusion provides the best distinction between healthy subjects, patients with moderate and patients with severe peripheral vascular disease. This finding confirms the statement of Fagrell and colleagues that the post-occlusive reactive hyperaemia response is of great value in nutritional skin microcirculatory research (40-43).

\subsection{CONCLUSION}

Nutritional skin blood flow at rest in the intact skin of patients with severe peripheral vascular disease is preserved in the sitting position. The maintenance of nutritional skin blood flow at rest likely results from dilation of arterioles. When this precapillary adjustment is almost at the maximum, progression of the disease and extemal skin compression probably account for an insufficient nutritional skin microcirculation, ultimately leading to the development of ischaemic skin lesions. The increase in the diameter of the arteriolar limbs of capillary loops, seen in the rims of ischaemic skin lesions, may be caused by metabolites, released from these ischaemic skin lesions. This increase in capillary diameter may be considered as an ultimate possibility to increase nutritional skin blood flow at rest. 
1. Gerlach. Ueber das Hautathmen. Arch Anat Physiol 1851;18:431-79.

2. Clark LC Jr. Monitor and control of blood and tissue oxygen tensions. Trans Am Soc Artif Intern Organs 1956:2:41-8.

3. Evans NTS. Naylor PFD. The systemic oxygen supply to the surface of human skin. Respir Physiol 1967;3:21-37.

4. Huch R, Lubbers DW, Huch $A$. Quantitative continuous measurement of partial oxygen pressure on the skin of adults and new-born babies. Pfligers Arch 1972;337:185-98.

5. Huch A, Huch R, Amer B, Rooth G. Continatous transcutaneous oxygen tension measured with a heated electrode. Scand J Clin Lab Invest 1973; $31: 269-75$.

6. Huch R, Lübbers DW, Huch $\Lambda$. Reliability of transcutaneous monitoring of arterial $\mathrm{PO}_{2}$ in newborn infants. Arch Dis Child 1974;49:213-8.

7. Peabody Jl, Willis MM, Gregory GA, Tooley WH, Lucey JF. Clinical limitations and advantages of transcutaneous oxygen electrodes. Acta Anaesthesiol Scand 1978; suppl 68:76-82.

8. Tremper KK, Shoemaker WC. Transcutaneous oxygen monitoring of critically ill adults, with and without low flow shock. Crit Care Med 1981;9:7069.

9. Tønnesen KH. Transcutaneous oxygen tension in imminent foot gangrene. Acta Anaesthesiol Scand 1978;suppl 68:107-10.

10. Spence VA, Walker WF. Tissue oxygen tension in nomal and ischaemic human skin. Cardiovasc Res 1984;18:140-4.

11. McCollum PT, Spence VA, Walker WF. Oxygen inhalation induced changes in the skin as measured by transcutaneous oxymetry. Br J Surg 1986;73:8825.

12. Clyne CAC, Ryan J, Webster JHH, Chant ADB. Oxygen tension on the skin of ischemic legs. Am J Surg 1982;143:315-8.

13. Mannarino E, Maragoni G, Pasqualini L, Sanchini R, Rossi P, Orlandi U. Transcutaneous oxygen tension behavior in the different stages of peripheral vascular disease and its correlation with ankle/arm pressure ratio and calf blood flow. Angiology 1987;38:463-8.

14. Christensen KS, Larsen JF, Klaerke M. Transcutaneous oxygen tension response to exercise in health and in occlusive arterial disease. Acta Chir Scand 1986;152:657-60.

15. Holdich TAH, Reddy PJ, Walker RT, Dormandy JA. Transcutaneous oxygen tension during exercise in patients with claudication. Br Med J 1986; 292:1625-8. 
16. White RA, Nolan L, Harley D et al. Noninvasive evaluation of penphera! vascular disease using tansculaneous oxygen tension. An J Surg 1982; 144:68-75.

17. Burgess EM. Matsen FA, Wyss CR, Simmons CW. Segmental transcutaneous measurements of $\mathrm{PO}$ in patients requiring below-the-knee amputation for peripheral vascular insufficiency. J Bone Joint Surg 1982;64-A: 378-82.

18. Sunder-Plassmann L, Melmer K, Becker IIM. Tissue $\mathrm{pO}_{2}$ and transcutaneous $\mathrm{pO}_{2}$ as guidelines in experimental and clinical drug evaluation. Angiology 1981;32:686-98.

19. Lalka SG, Malone JM, Anderson GG, Hagaman RM, Melntyre KE, Bernhard VM. Transcutaneous oxygen and carbon dioxide pressure monitoring to determine severity of limb ischemia and to predict surgical outcome. J Vasc Surg 1988:7:50\%-14.

20. Rhodes GR, King TA. Delayed skin oxygenation following distal tibial revascularization (dtr). Implications for wound healing in late amputations. Am Surg 1986;52:519-25.

21. Heidrich H, Lammersen Th. Vitalkapillarmikroskopische Untersuchungen

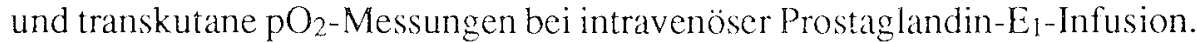
Dtsch Med Wochenschr 1985;110:1283-5.

22. Davis E, Landau J, eds. Clinical capillary microscopy. Springfield: Charles C. Thomas Publisher, 1966.

23. Weiß E. Beobachtung und mikrophotographische Darstellung der Hautkapillaren am lebenden Menschen. Dtsch Arch Klin Med 1916;119:1-38.

24. Fagrell B. Vital capillary microscopy. A clinical method for studying changes of the nutritional skin capillaries in legs with arteriosclerosis obliterans. Scand J Clin Lab Invest 1973;31 (suppl 133):1-50.

25. Lombard WP. The blood pressure in the arterioles, capillaries, and small veins of the human skin. Am J Physiol 1912; 29:335-62.

26. Danzer CS, Hooker DR. Determination of the capillary blood pressure in man with the micro-capillary tonometer. Am J Physiol 1920;52:136-67.

27. Müller O, ed. Die Kapillaren der menschlichen Körperober fläche in gesunden und kranken Tagen. Stuttgart: Ferdinand Enke Verlag, 1922.

28. Crawford $\mathbf{J H}$, Rosenberger $\mathrm{H}$. Studies on human capillaries. I. An apparatus for cinematographic observation of human capillaries. J Clin Invest 1926; 2:343-9.

29. Gilje O. Capillary microscopy in the differential diagnosis of skin diseases. Acta Derm Venereol 1953;33:303-17.

30. Ryan TJ. Capillary microscopy and the skin. Br J Derm 1970; 82(suppl 5):74-6. 
31. Fagrell B. Vital capillary microscopy for estimating the viability of the skin in regions suffering from arterial insufficiency [Abstract]. Microvasc Res 1971:3:440-1.

32. Fagrell B. A clinical method for studying changes of skin microcirculation in patients suffering from vascular disorders of the leg. Angiology 1972;23:28498.

33. Slaaf DW, Arts T, Jeurens TJM, Tangelder GJ, Reneman RS. Electronic measurement of red blood cell velocity and volume flow in microvessels. In: Chayen J, Bitensky L, eds. Investigative microtechniques in medicine and biology (Volume 1). New York: Marcel Dekker Inc., 1984:327-64.

34. Bollinger A, Butti P, Barras JP, Trachsler H, Siegenthaler W. Red blood velocity in nailfold capillaries of man mcasured by a television microscopy technique. Microvasc Res 1974;7:61-72.

35. Maricq HR, Spencer-Green G, LeRoy EC. Skin capillary abnormalities as indicators of organ involvement in scleroderma (systemic sclerosis), Raynaud's syndrome and dermatomyositis. Am J Med 1976;61:862-70.

36. Bollinger A. Contribution of dynamic microvascular studies to pathophysiology and diagnosis of Raynaud's phenomenon. Adv Microcirc 1985;12:8294.

37. Houtman N. Microvascular and immunological studies in Raynaud's phenomenon. Groningen, The Netherlands: University of Groningen, 1985. 126 pp. Dissertation.

38. Jacobs MJHM. Capillary microscopy and haemorheology in vasospastic and occlusive vascular diseases. Maastricht, The Netherlands: University of Limburg, 1985. 125 pp. Dissertation.

39. Jacobs MJHM, Breslau PJ, Slaaf DW, Reneman RS, Lemmens JAJ. Nomenclature of Raynaud's phenomenon: A capillary microscopic and hemorheologic study. Surgery 1987;101:136-45.

40. Fagrell B, Fronek A, Intaglietta M. Capillary flow components and reactive hyperemia in human skin capillaries studied by clinical television microscopy. Bibl Anat 1977;16:112-5.

41. Fagrell B, Fronek A, Intaglietta M. Capillary blood flow velocity during rest and post-occlusive reactive hyperemia in skin areas of the toes and lower leg. Bibl Anat 1977;16: 159-61.

42. Fagrell B. Postocclusive reactive hyperemia reponse in human skin capillaries. Bibl Anat 1981;20:671-4.

43. Fagrell B, Tooke J, Östergren J. Vital capillaroscopy for evaluating skin microcirculation in humans. Prog Appl Micro circ 1984;6:129-40.

44. Beckers RCY, Jacobs MJHM, Jörning PJG, Kooman JP, Slaaf DW, Reneman RS. Microcirculatory investigation can distinguish between patients with intermittent claudication and healthy persons [Abstract]. Int J Microcirc Clin Exp 1988; special issue: S37. 
45. Slaaf DW, Tangelder GJ, Reneman RS, Jäger $K$, Bollinger $A$. A versatile incident illuminator for intravital microscopy. Int J Microcirc Clin Exp 1987:6:391-7

46. Fagrell B. Fronck A. Intaglietta M. A microscope-television system for studying flow velocity in human skin capillaries. Am J Physiol 1977; 233:11318-11321.

47. Brannemark PI, Jonsson I. Determination of the velocity of corpuscles in blood capillaries. A flying spot device. Biorheology 1963:1:143-6.

48. Tyml K, Ellis CG. Evaluation of the flying spot technique as a television method for measuring red cell velocity in microvessels. Int $\mathbf{J}$ Microcirc Clin Exp 1982;1:145-55.

49. Boss Ch, Schneuwly P, Mahler F. Evaluation and clinical application of the flying spot method in clinical nailfold capillary TV-microscopy. Int J Microcirc Clin Exp 1987;6:15-23.

50. Franzeck UK, Talke P, Bernstein EF, Golbranson FL, Fronek $\triangle$. Transcutaneous $\mathrm{PO}_{2}$ measurements in health and peripheral arterial occlusive disease. Surgery 1982;91:156-63.

51. Kram HB, White RA, Tabrisky J, Appel PL, Fleming AW, Shoemaker WC. Transcutaneous oxygen recovery and toe pulse reappearance time in the assessment of peripheral vascular disease. Circulation 1985;72:1022-7.

52. Eickhoff JH, Ishihara S, Jacobsen E. Effect of arterial and venous pressures on transcutaneous oxygen tension. Scand J Clin Lab Invest 1980;40:755-60.

53. Creutzig A, Dau D, Caspary L, Alexander K. Transcutaneous oxygen pressure measured at two different electrode core temperatures in healthy volunteers and patients with arterial occlusive disease. Int J Microcirc Clin Exp 1987; 5:373-80.

54. Creutzig A, Caspary L, Alexander K. Disturbances of skin microcirculation in patients with chronic arterial occlusive disease and venous incompetence. Vasa 1988; 17:77-83.

55. Byme P, Provan JL, Ameli FM, Jones DP. The use of transcutaneous oxygen tension measurements in the diagnosis of peripheral vascular insufficiency. Ann Surg 1984;200:159-65.

56. Amery A, Bossaert H, Deruyttere M, Vanderlinden L, Verstraete M. Influence of body posture on leg blood flow. Scand J Clin Lab Invest 1973;31 (suppl 128):29-36.

57. Henriksen O. Local reflex in microcirculation in human subcutaneous tissue. Acta Physiol Scand 1976;97:447-56.

58. Creutzig A, Caspary L, Hertel RF, Alexander K. Temperature-dependent laser Doppler fluxmetry in healthy and patients with peripheral arterial occlusive disease. Int J Microcirc Clin Exp 1987;6:381-90.

59. Hassan AAK, Tooke JE. Mechanism of the postural vasoconstrictor response in the human foot. Clin Sci 1988;75:379-87. 


\section{CHAPTER 5}

\section{RELATION BETWEEN THE MACROCIRCULATION AND THE SKIN MICROCIRCULATION}

In this chapter the relation between the macrocirculation, as examined with the use of toe systolic blood pressure (TSBP) and arteriography, and the skin microcirculation, as investigated with the use of $\mathrm{cpO}_{2}$ monitoring and intravital skin capillary microscopy, is presented. The reasons for preferring TSBP to ankle systolic blood pressure to provide information about the condition of the macrocirculation, have been given in chapter 4 . The relation between the results of tcpO $\mathrm{O}_{2}$ and TSBP measurements in the sitting position is not discussed in this chapter, because these measurements were performed under different experimental conditions. $\mathrm{TcpO}_{2}$ was monitored during local skin heating (electrode core temperature $44^{\circ} \mathrm{C}$ ), which overrules vasoconstrictive mechanisms normally elicited upon leg dependency in healthy subjects and patients with moderate peripheral vascular disease, while TSBP measurements were performed without heating the skin (1-8).

\subsection{RELATION BETWEEN THE SKIN MICROCIRCULATION AND TOE SYSTOLIC BLOOD PRESSURE (TSBP)}

The relation between skin oxygen delivery at rest (RESTING $\mathrm{TCPO}_{2}$ ), which reflects total skin blood flow at rest, and TSBP in the supine position in patients with moderate and severe peripheral vascular disease (F2-group and F3/4-group, respectively) and healthy subjects (control-group), is visualized in Figure 5.1.

The absence of a significant difference between RESTING TCPO2 values of patients with peripheral vascular disease (range: $35-82 \mathrm{~mm} \mathrm{Hg}$ ) and healthy subjects (indicated by $\Delta$ in Figure 5.1), who have a TsBP higher than $60 \mathrm{~mm} \mathrm{Hg}$, 
RESTING TCPO 2 in $\mathrm{mm}$ Hg (supine:

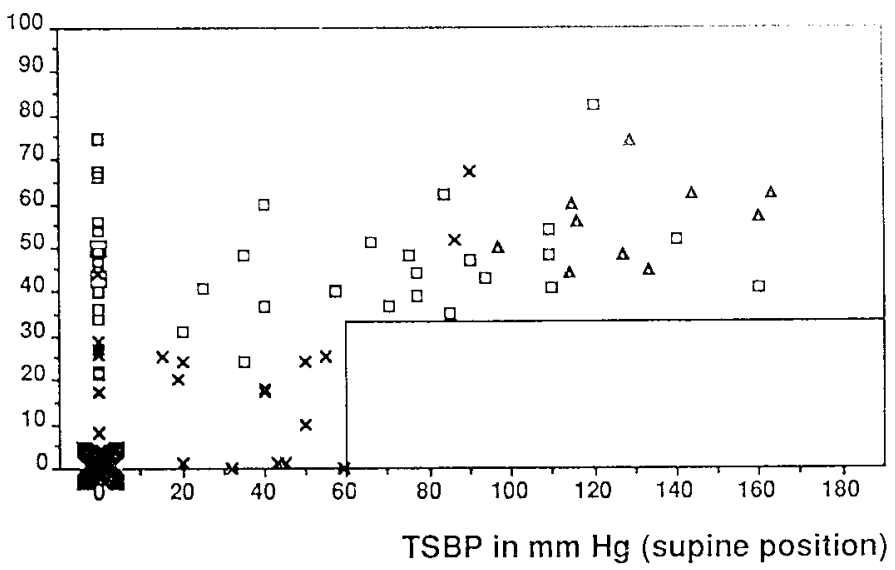

Figure 5.1 Stable baseline tcpO $\mathrm{O}_{2}$ at rest at the dorsum of the first metatarsophalangeal joint of the foot (RESTING TCPO2) in the supine position for toe systolic blood pressure (TSBP) in the supine position in healthy subjects ( $\Delta=$ control-group) and in patients with various degrees of peripheral vascular disease according to Fontaine's classification $(\square=F 2$-group and $\times=$ F3/4-group. The size of the symbol corresponds to the number of data points that coincide at that location.

$\mathrm{T} 50 \% \mathrm{TCPO}_{2}$ in s (supine position)

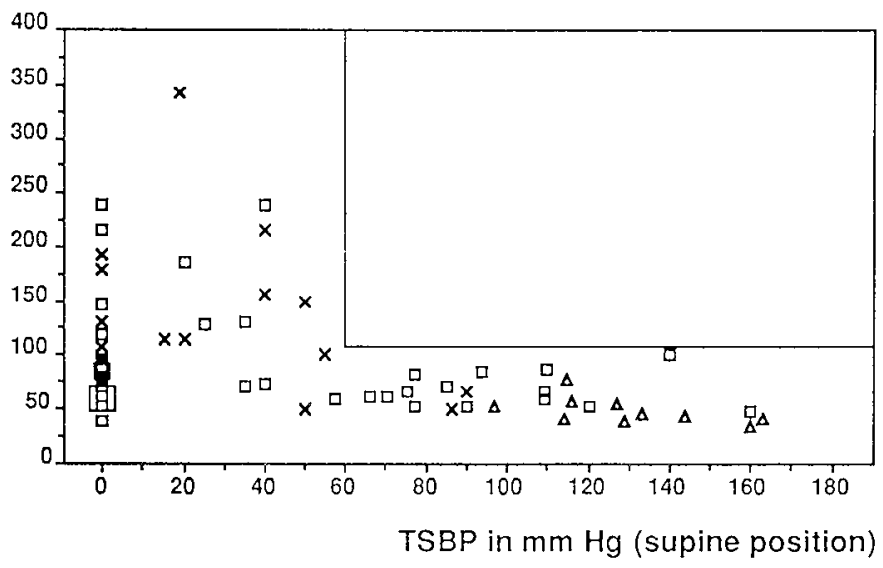

Figure 5.2 Time needed to reach $50 \%$ of the RESTING $\mathrm{TCPO}_{2}$ at the dorsum of the first metatarsophalangeal joint of the foot following the release of a transient arterial occlusion (T50\% $\mathrm{TCPO}_{2}$ ) in the supine position for toe systolic blood pressure (TSBP) in the supine position in healthy subjects ( $\triangle=$ control-group) and in patients with various degrees of peripheral vascular disease according to Fontaine's classification ( $\square=$ F2-group and $x=F 3 / 4$ - group. The size of the symbol corresponds to the number of data points that coincide at that location. 


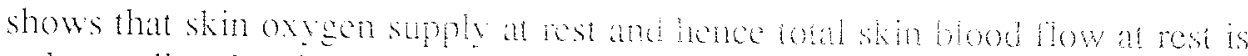

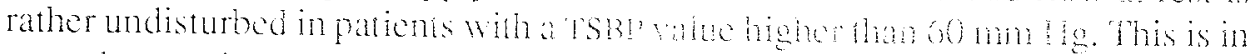
accordance with the finding of Krihenotht and colleases, who reported that a TSBP value of $50 \mathrm{~mm}$ Hg or higher was associated whe tiomat skin oxygen delivery at rest (9). In patients with TSBP values below 60 niml $b$, the range of

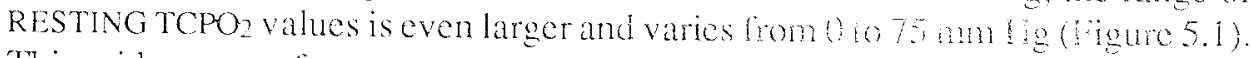
This wide range of RESTING TCPO2 values indicases hat TSBP values be low 60 mm Hg in patients with peripheral vascular disease do mat prodict skin oxygen delivery at rest and that oxygen supply at rest does not reflect he condition of the macrocirculation. The large number of patiens (13 out of 16 ) suffering from moderate peripheral vascular disease ( $F 2$-group) with a TSBP value of 0 mm $11 \mathrm{~g}$ and a rather normal skin oxygenation at rest (RESTING TCPO $>3+$ mm IIg) can probably be explained by the fact that patiens, in whon no pulsatility could be detected photoplethysmographically, were classified as having a TSBP of $0 \mathrm{~mm}$. $\mathrm{Hg}$ (chapter 3 ). In view of the RESTING TCPO2 values, however, a considerable amount of blood has to reach the skin in these paticnts, which indicates that the mean arterial pressure is still substantial. The very low RESTING TCPO2 values of 0 and $1 \mathrm{~mm} \mathrm{Hg}$ in the presence of TSBP values ranging from $2010.59 \mathrm{~mm} \mathrm{Hg}$ in 5 patients with severe peripheral vascular disease ( $13 / 4$-group) is caused neither by overestimation of TSBP values (range of toe-to-brachial systolic blood pressure index: 12-32\%) nor by an extremely low systemic level of skin oxygen delivery at rest (range of skin oxygen delivery at rest at the chest: $47-66 \mathrm{~mm} \mathrm{Hg}$ ). Since in other patients the same range of TSBP is associated with a quite normal skin oxygen delivery at rest, the extremely low amount of oxygen supplied to the skin at rest in these 5 patients can probably be explained by obstructions at the skin microcirculatory level. As shown in Figure 5.2, a TSBP value of $60 \mathrm{~mm} \mathrm{IIg}$ is also a cut-off point as far as the response to the release of a transient arterial occlusion ( $\left.550 \% \mathrm{TCPO}_{2}\right)$, which indirectly reflects the degree of arteriolar dilation at rest, is concerned.

In patients with a TSBP value higher than $60 \mathrm{~mm}$ Hg the degree of arteriolar dilation at rest appears to be equal to that in healthy subjects. In patients with a TSBP value below $60 \mathrm{~mm} \mathrm{Hg}$, however, $\mathrm{T} 50 \% \mathrm{TCPO}_{2}$ indicates a normal or increased degree of arteriolar dilation at rest. In other words, in patients with peripheral vascular disease, who have a TSBP value higher than $60 \mathrm{~mm} \mathrm{Hg}$ in the supine position, tcpO monitoring in this position can be omitted, because a normal peripheral skin oxygen delivery at rest is to be expected. TcpO $\mathrm{O}_{2}$ monitoring in the supine position, however, is of importance in patients with TSBP values below $60 \mathrm{~mm} \mathrm{Hg}$, when one has to be informed of their skin oxygen supply at rest and hence their total skin blood flow at rest.

As shown in Figures 5.3-5.7, in the sitting position no relation exists between TSBP on the one hand, and nutritional skin blood flow at rest (NSBF), the degree of arteriolar dilation at rest (RBCVI, TrP), the diameter of the arteriolar limbs of 
NSBF $\times 10^{-3}$ in $\mathrm{mm}^{3} / \mathrm{s}$ (sitting position)

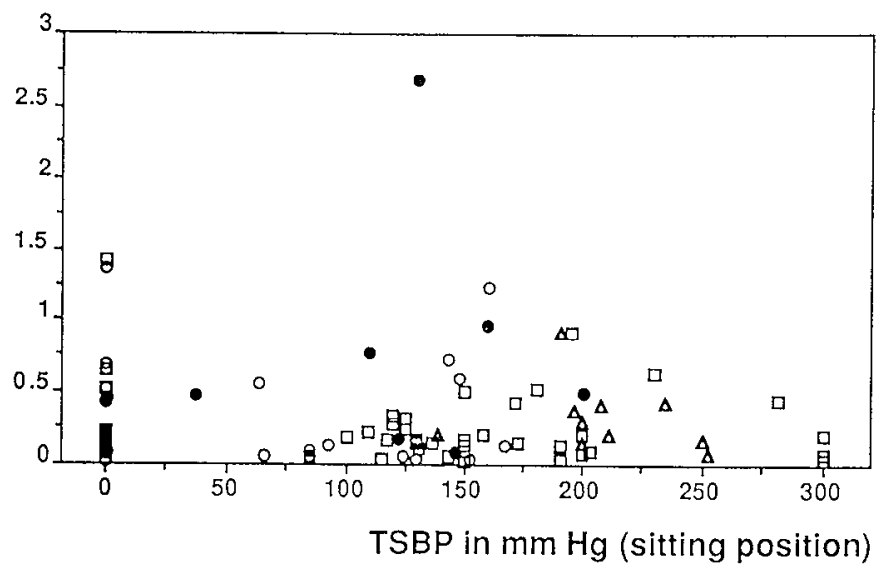

Figure 5.3 Nutritional skin blood flow at rest per $\mathrm{mm}^{2}$ of the investigated skin surface area (NSBF) in the sitting position for toe systolic blood pressure (TSBP) in the sitting position in healthy subjects ( $\Delta=$ control-group) and in patients with various degrees of peripheral vascular disease according to Fontaine's classification $(\square=$ F2-group, $O=$ F3/4-INTACT -group and $\bullet=$ F3/4-LESION-group). The size of the symbol corresponds to the number of data points that coincide at that location.

\section{RBCVI (sitting position)}

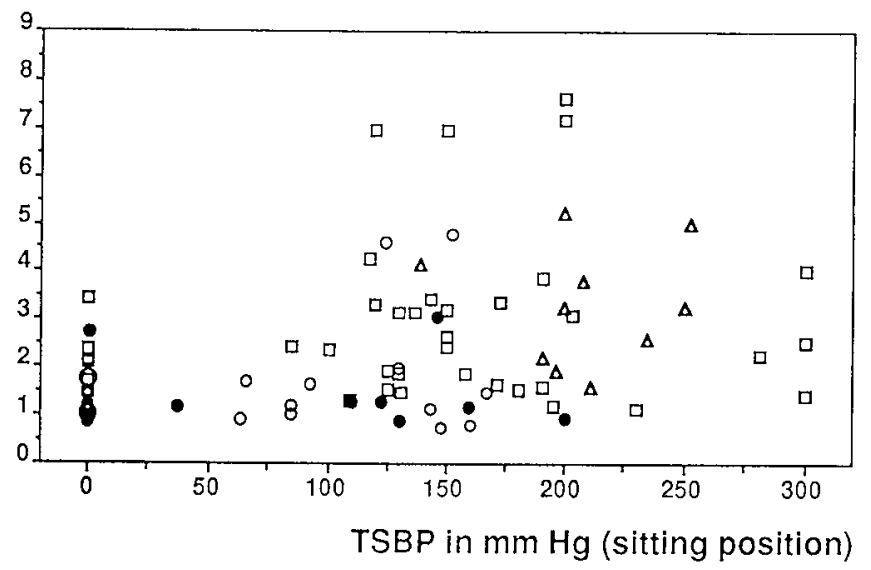

Figure 5.4 Ratio of peak red blood cell velocity following the release of a transient arterial occlusion to red blood cell velocity at rest (RBCVI (red blood cell velocity index)) in the sitting position for toe systolic blood pressure (TSBP) in the sitting position in healthy subjects $(\Delta=$ control-group) and in patients with various degrees of peripheral vascular disease according to Fontaine's classification ( $\square=F 2$-group, $O=F 3 / 4$-INTACT-group and $\bullet=$ F3/4-LESION-group). The size of the symbol corresponds to the number of data points that coincide at that location. 
TP in s (sitting position)

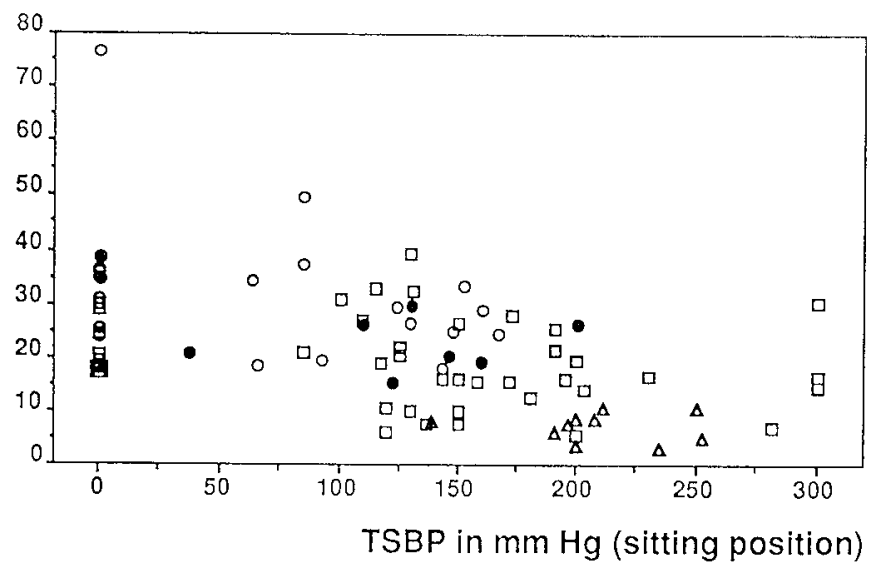

Figure 5.5 Time-to-peak red blood cell velocity following the release of a transient arterial occlusion (TTP) in the sitting position for toe systolic blood pressure (TSBP) in the sitting position in healthy subjects ( $\Delta=$ control-group) and in patients with various degrees of peripheral vascular disease according to Fontaine's classification $(\square=F 2$-group, $O=F 3 / 4$-INTACT-group and $\bullet=$ F3/4-LESION-group). The size of the symbol corresponds to the number of data points that coincide at that location.

\section{DIAMETER in $\mu \mathrm{m}$ (sitting position)}

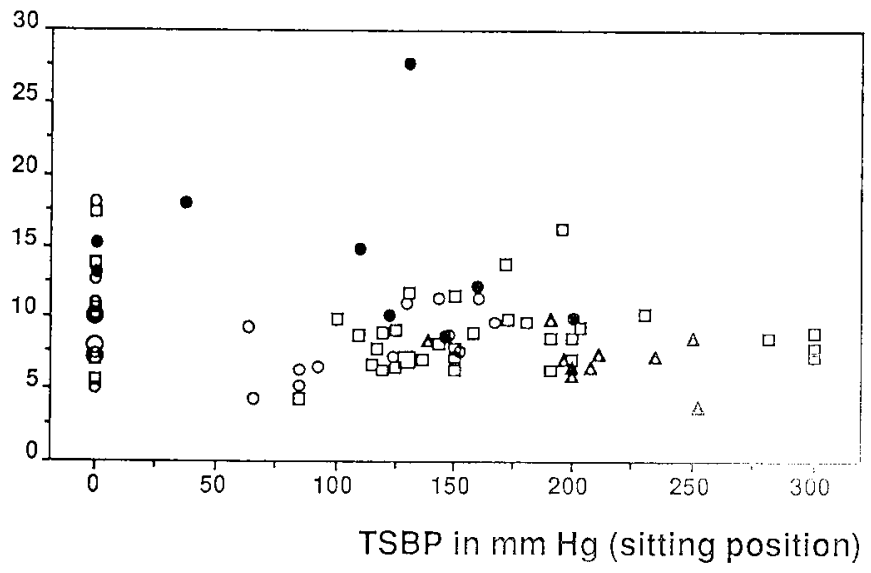

Figure 5.6 Diameter of the arteriolar limbs of capillary loops (DIA for toe systolic blood pressure (TSBP) in the sitting position in he group) and in patients with various degrees of peripheral vas Fontaine's classification ( $\square=$ F2-group, $O=$ F3/4-INTACT-group ar The size of the symbol corresponds to the number of data points th. 


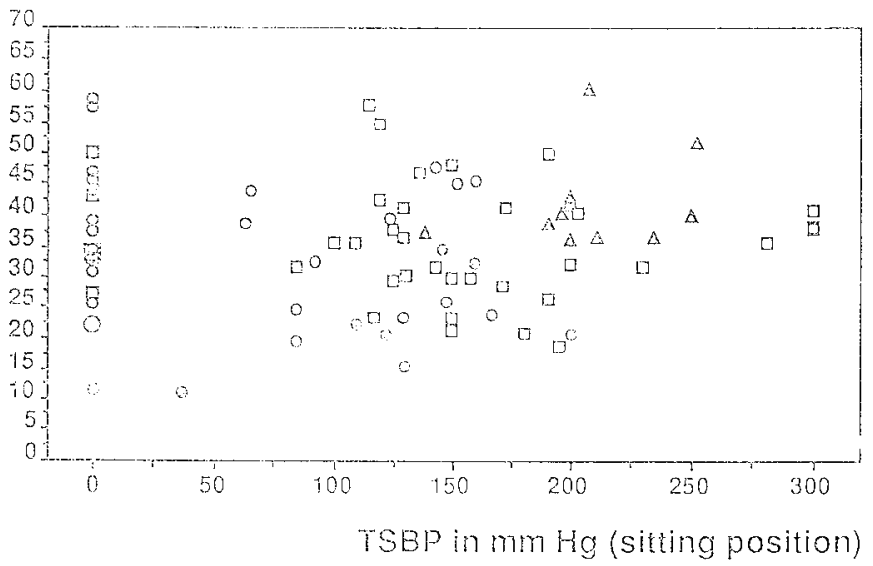

Figure 5.7 Number of bood-lilled capillaries per mm of the investigated skin surface area (DENSTYY) in the sitting position for toe systolic blood pressure (TSBb) in the sitting position in healthy subjects $(A=$ control-gronp) and in patients with varous degrees of peripheral vascular

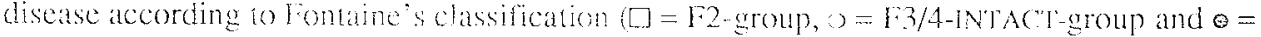
3.3/4-LESION-gromp). The size of the symbol corresponds to the number of data points that coincide at that location.

capillary loops (DAviente) and the number of blood-illied capillaries per $\mathrm{mm}^{2}$ of the investignted sin surtace area (DENSITY) on the other. Furthemore, in paticnts with peripheral vascular discase the signilicant difference in DIAMETLR and DENSITY botween intact skin parts (F-2-group (a) and 13/4-INTACT-group (0)) and rims of ischacmic skin besion ( $3 / 4$-LESION-group (a)) is not reflected in the TSBP nor is the signilicant difcence in the degree of arteriolar dilation at rest (RBCVI) between patients with moderate ( $F 2$-group ( $\square$ ) and severe peripheral vascular disease (B3/4-INTACT-group (O) and P3/4-LESION-group (*).

These results indicate that in the sitting position no relation exists between the macrocirculation, as investigated with the use of TSBP measurements, and the nutritional skin microcirculation, as assessed by means of intravital skin capillary microscopy. In the sitting position macrocirculatory TSBP values do not provide information about the condition of the nutritional skin microcirculation. Irrespective of the outcome of TSBP measurements in the sitting position, intravital skin capillary microscopy should be performed to gain insight into the nutritional skin microcirculation. 


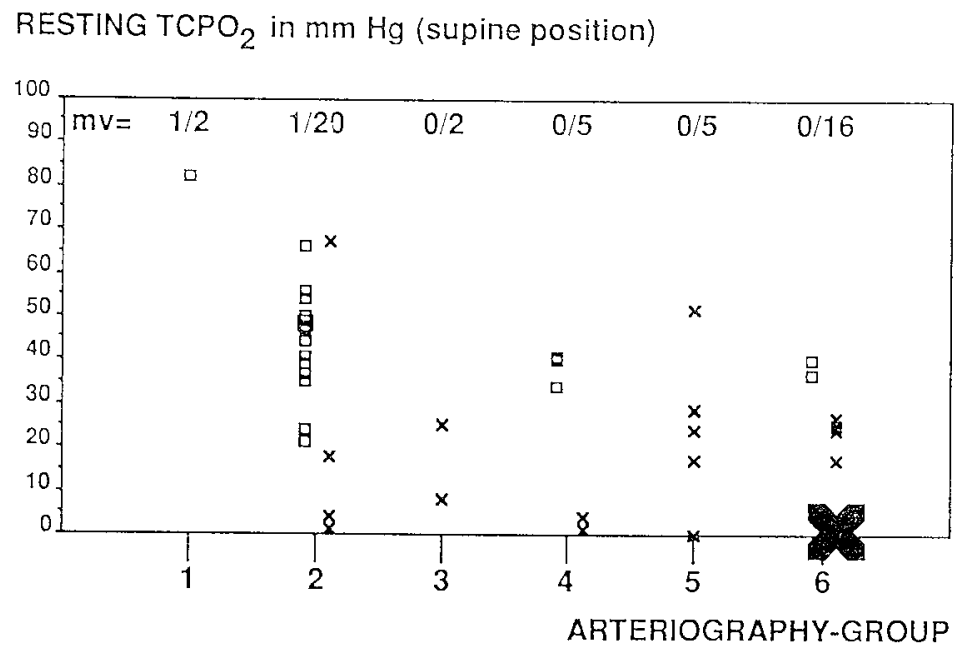

Figure 5.8 Stable baseline tep $\mathrm{O}_{2}$ at rest at the dorstum of the first metatarsophalangeal joint of the foot (RESTING ' $\mathrm{TCPO}_{2}$ ) in the supine position for the various ARTERIOGRAPHY-GROUPS, representing progressive arteriographic degrees of macrocirculatory obstruction; $\square=\mathrm{F} 2$-group, $x=$ F3/4-group. The size of the symbol corresponds to the number of data points that coincide at that location; abscissa: 1 = ARTERIOGRAPHY-GROUP 1, 2 = ARTTRIOGRAPHY-GROUP 2, etC; mv $=$ missing value $(s)$.

\subsection{Relation between the skin microcirculation and arteriography}

Scatter plots, displaying the relation between the degree of macrocirculatory obstruction, as visualized arteriographically, on the one hand, and total and nutritional skin blood flow at rest (RESTING $\mathrm{TCPO}_{2}$ (supine) and NSBF (sitting), respectively) and the degree of arteriolar dilation at rest ( $50 \% \mathrm{TCPO}_{2}$ (supine) and TTP (sitting), respectively) on the other, are shown in Figures 5.8-5.11. TcpO parameters in the supine position and nutritional skin microcirculatory parameters in the sitting position are not significantly different in the various ARTERIOGRAPHY-GROUPS. This indicates that the arteriographic degree of macrocirulatory obstruction neither reflects the condition of the total skin microcirculation nor that of the nutritional skin microcirculation and vice versa. 
NSBF $\times 10^{-3}$ in $\mathrm{mm}^{3} / \mathrm{s}$ (sitting position)

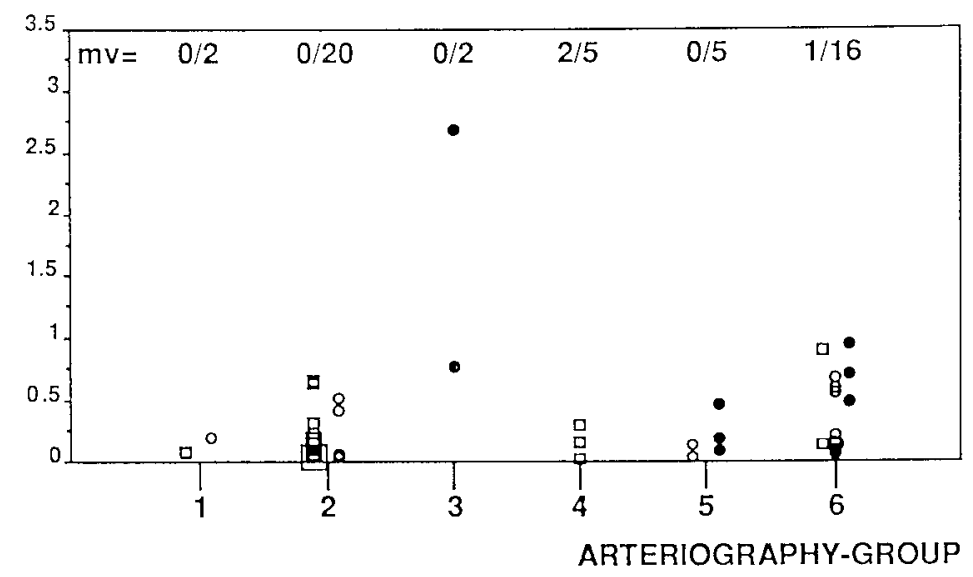

Figure 5.9 Nutritional skin blood flow at rest per $\mathrm{mm}^{2}$ of the investigated skin surface area (NSBF) in the sitting position for the various ARTERIOGRAPHY-GROUPS, representing progressive arteriographic degrees of macrocirculatory obstruction; $\square=$ F2-group, $O=F 3 / 4$-INTACT . group, $\bullet=$ F3/4-LESION-group. The size of the symbol corresponds to the number of data points that coincide at that location; abscissa: $1=$ ARTERIOGRAPHY-GROUP 1, 2 = ARTERIOGRAPHYGROUP 2, etc; mv = missing value(s).

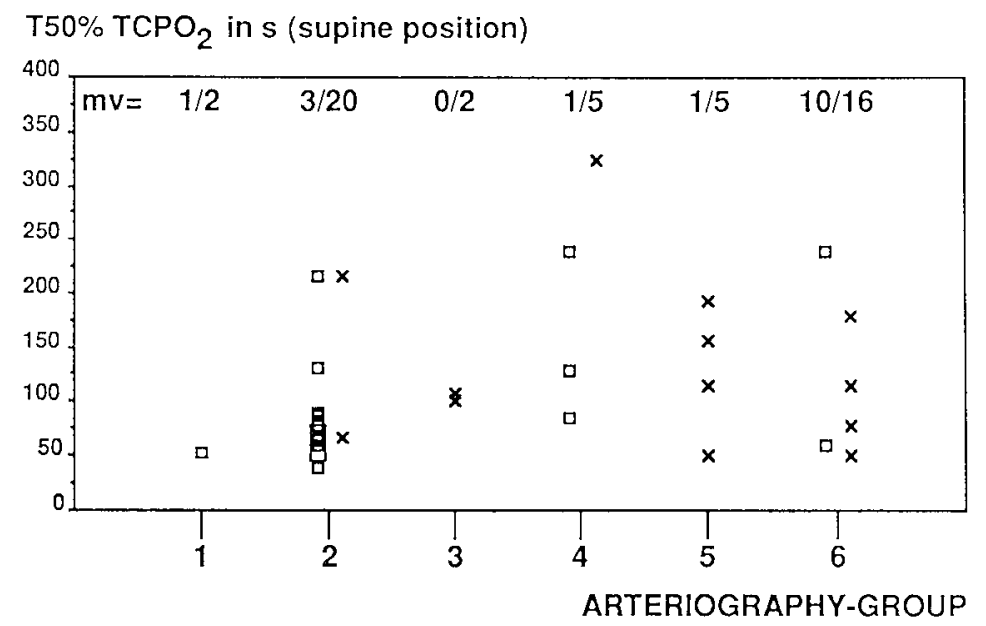

Figure 5.10 Time needed to reach $50 \%$ of the RESTING $\mathrm{TCPO}_{2}$ at the dorsum of the first metatarsophalangeal joint of the foot following the release of a transient arterial occlusion (T50\% $\mathrm{TCPO}_{2}$ ) in the supine position for the various ARTERIOGRAPHY-GROUPS, representing progressive arteriographic degrees of macrocirculatory obstruction; $\square=F 2$-group, $x=F 3 / 4$-group. The size of the symbol corresponds to the number of data points that coincide at that location; abscissa: 1 = ARTERIOGRAPHY-GROUP 1, 2 = ARTERIOGRAPHY-GROUP 2, etc; mv = missing value(s). 
TTP in s (sitting position)

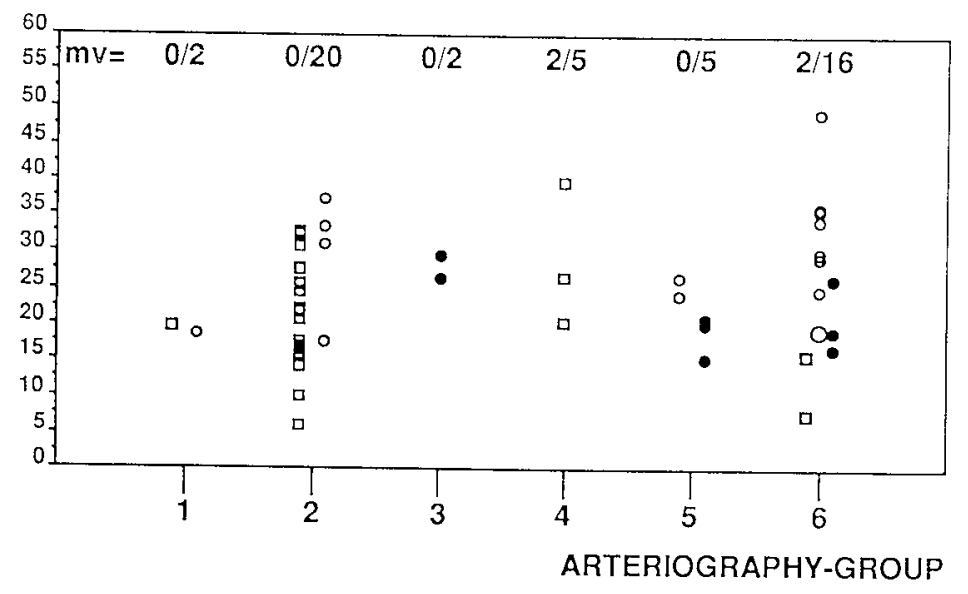

Figure 5.11 Time-to-peak red blood cell velocity following the release of a transient arterial occlusion (TTP) in the sitting position for the various ARTERIOGRAPHY-GROUPS, representing progressive arteriographic degrees of macrocirculatory obstruction; $\square=$ F2-group, $O=F 3 / 4$-INTACT-group, $\bullet=$ F3/4-LESION-group. The size of the symbol corresponds to the number of data points that coincide at that location; abscissa: $1=$ ARTERIOGRAPHY-GROUP $1,2=$ ARTERIOGRAPHY-GROUP 2, etc; mv = missing value(s).

\subsection{CONCLUSION}

In patients with moderate and severe peripheral vascular disease (stages 2, 3 and 4 according to Fontaine) a TSBP higher than $60 \mathrm{~mm} \mathrm{Hg}$ in the supine position is indicative of a relatively undisturbed total skin oxygenation at rest and hence a normal total skin blood flow at rest. TSBP values below $60 \mathrm{~mm} \mathrm{Hg}$, however, do not predict the level of total skin blood flow at rest nor does the degree of macrocirculatory obstruction, as visualized arteriographically. The necessity for tcpO $\mathrm{O}_{2}$ monitoring to be sure of an uncompromised total skin blood flow at rest in patients with moderate and severe peripheral vascular disease entirely depends on the outcome of TSBP measurements. Since TSBP, determined in the sitting position, and results of arteriography do not have any predictive value at all for the condition of the nutritional skin microcirculation, investigations with the use of intravital skin capillary microscopy are indispensable irrespective of the results of TSBP measurements and arteriography. In other words, intravital skin capillary microscopy is the only method presently available, that directly provides information about the condition of the nutritional skin microcirculation. 


\section{$5.4 \quad$ REFERENCES}

1. Eickhoff JH, Ishihara S, Jacobsen E. Effect of anterial anci venous pressures on transcutaneous oxygen tension. Scand J Clin Lab Invest 1980;40:755-60.

2. Creutzig A, Dau D, Caspary L, Alexander K. Transcutaneous oxygen pressure measured at two different electrode core temperatures in healthy volunteers and patients with arterial occlusive discase. Int J Microcirc Clin Exp $1987 ; 5: 373-80$.

3. Creutzig A, Caspary L, Alexander K. Disturbances of skin microcirculation in patients with chronic arterial occlusive disease and venous incompetence. Vasa 1988; 17:77-83.

4. Byrne P, Provan JL, Ameli FM, Jones DP. The use of transcutaneous oxygen tension measurements in the diagnosis of peripheral vascular insufficiency. Ann Surg 1984;200:159-65.

5. Amery A, Bossacrt H, Deruyttere M, Vanderlinden L, Verstraete M. Influence of body posture on leg blood flow. Scand J Clin Lab Invest 1973;31 (suppl 128):29-36.

6. Henriksen $O$. Local reflex in microcirculation in human subcutaneous tissue. Acta Physiol Scand 1976;97:447-56.

7. Creutzig A, Caspary L, Hertel RF, Alexander K. Temperature-dependent laser Doppler fluxmetry in healthy and patients with peripheral arterial occlusive disease. Int J Microcirc Clin Exp 1987;6:381-90.

8. Hassan AAK, Tooke JE. Mechanism of the postural vasoconstrictor response in the human foot. Clin Sci 1988;75:379-87.

9. Krähenbühl B, Dubas JM. Transcutaneous oxygen pressure on the foot of normal subjects and patients suffering from arterial occlusive disease. In: Jageneau AHM, ed. Noninvasive methods on cardiovascular haemodynamics. Amsterdam: Elsevier/North-Holland Biomedical Press, 1981:469-74. 


\section{CHAPTER 6}

\section{GENERAL DISCUSSION}

In general, only the condition of the macrocirculation is investigated in patients suffering from atherosclerotic arterial obstructive disease of the lower limbs, who are routinely classified according to the stages of Fontaine (1). At present, techniques like Doppler ultrasound, plethysmography and arteriography are used to obtain information about the condition of the macrocirculation. Ischaemic skin lesions in patients with severe peripheral vascular disease are indicative of a disturbance at the level of the skin microcirculation in addition to a compromised macrocirculation. Consequently, macrocirculatory as well as skin microcirculatory investigations should be performed to evaluate the total vascular state of patients suffering from peripheral vascular disease. The skin microcirculation, which consists of a nutritional and a thermoregulatory part, is referred to as total skin microcirculation. The nutritional part of the skin microcirculation, which comprises the capillaries providing the nutrition of the skin, can directly be visualized and investigated with the use of intravital skin capillary microscopy. Information about the total skin microcirculation can be obtained indirectly by monitoring transcutaneous oxygen pressure (tcpO $\mathrm{O}_{2}$ ). Both skin microcirculatory techniques are non-invasive.

The aims of this thesis were 1) to investigate both the macrocirculation, and the total and nutritional skin microcirculation in patients with various degrees of lower limb ischaemia according to the classification of Fontaine by means of the aforementioned techniques, and 2) to obtain information about the relation, if any, between macrocirculatory data on the one hand and total and nutritional skin microcirculatory data on the other. An additional aim of this thesis was to gain more insight into the ways, in which the skin microcirculation can adjust to macrocirculatory impairments.

The present study shows that arteriolar dilation serves as a functional adjustment at the precapillary level trying to maintain adequate nutritional skin blood flow at rest and hence to prevent skin damage in case of deteriorating blood supply due to arterial vascular disease. If, however, arterial vascular disease is severe and arterioles have reached their maximum dilation, progression of the disease probably results in insufficient nutritional skin blood flow at rest and hence the 
development of ischaemic skin lesions, In response to fiste damme, capilaries are able to increase their diameter in an attemp bo lower peripheral resistance and hence improve nutritional skin blood flow at resi.

The results of haemodynamic macrocirculatory invesigations in healthy subjects and patients suffering from peripheral vascular disease show that the condition of the lower limb macrocirculation is best reflected in the level of the toe systolic blood pressure (TSBP), as determined in the sitting position (chapter 3). Ankle systolic blood pressure (ASBP) and hence ankle-to-brachial systolic blood pressure index (ABI) appears to be artificially elevated, due to the presence of arterial wall rigidity (Mönckeberg's sclerosis), in a considerable number of patients with severe peripheral vascular disease $(24 \%)$, all of whom except one suffer from diabetes mellitus. This finding questions the general applicability of ASBP and ABI measurements to assess the quality of the macrocirculation in patients with severe peripheral vascular disease and especially in those with diabetes mellitus (chapter 3). Because rigidity of digital arteries due to calcification is uncommon and hence artificial elevation of TSBP is unlikely, TSBP measurements, performed in the sitting position, are preferred to ABI measurements to assess the condition of the macrocirculation in general and especially in patients with severe peripheral vascular disease suffering from diabetes mellitus (chapter 3) (2). Arteriography only gives anatomic information about the localization and extent of macrocirculatory obstructions. It does not provide haemodynamic information, as indicated by the considerable overlap between the degrees of macrocirculatory obstruction, as visualized arteriographically, and the outcome of ASBP and TSBP, and ABI and TBI (toe-to-brachial systolic blood pressure index) measurements (chapter 3).

The present study indicates that an impaired macrocirculation, as investigated with the use of TSBP measurements, is not necessarily related to a compromised total skin perfusion, as assessed with the use of transcutaneous $\mathrm{pO}_{2}\left(\operatorname{tcpO} \mathrm{O}_{2}\right.$ ) monitoring with a heated tcpO $\mathrm{O}_{2}$ electrode (chapter 5). A TSBP value of $60 \mathrm{~mm} \mathrm{Hg}$ in the supine position appears to be a cut-off point as far as total skin blood flow at rest, measured by tcpO 2 monitoring, is concerned (chapter 5). In patients suffering from peripheral vascular disease a TSBP higher than $60 \mathrm{~mm} \mathrm{Hg}$ is indicative of a normal total skin blood flow at rest. Below a TSBP value of $60 \mathrm{~mm}$ $\mathrm{Hg}$, however, TSBP has no predictive value anymore and $\mathrm{tcpO}_{2}$ monitoring is necessary to assess the extent of total skin perfusion at rest.

The results of intravital skin capillary microscopy suggest that in the sitting position with the legs dependent nutritional skin blood flow at rest in the intact skin of the foot of patients with severe peripheral vascular disease does not differ significantly from that of healthy subjects and patients with less severe peripheral vascular disease, despite their severely impaired macrocirculatory blood supply (chapter 4). Under disturbed macrocirculatory circumstances nutritional skin blood flow at rest can be adequately maintained by arteriolar dilation, preventing the development of skin damage. The increase in red blood cell velocity following 
the release of a transient arterial occlusion in patients with severe peripheral vascular disease appears to be extremely low (chapter 4). This indicates that their arterioles at rest are almost dilated at the maximum and hence their arteriolar reactivity at rest is diminished considerably. Furthermore, it confirms that vasoconstrictive mechanisms, which are nomally elicited upon leg dependency, are seriously impaired, if not abolished, in patients with severe peripheral vascular disease (3-9). A decrease in arteriolar reactivity, however, appears to be reversible, as shown in a recent study of Jacobs and colleagues (10). In their study, the post-occlusive reactive hyperaemia response was improved after successful reconstructive vascular surgery, indicating arteriolar dilation at rest to be decreased. Since the present study indicates that at rest the arterioles in the intact skin of patients suffering from severe peripheral vascular discase are almost dilated at the maximum and no additional compensatory mechanism is available at the precapillary level anymore, a (further) reduction in nutritional sk in blood flow at rest, caused by a progression of the disease and/or external skin compression, is likely to result in the development of ischaemic skin lesions.

In the sitting position the number of blood-filled capillaries and hence the surface area for exchange in the rims of ischaemic skin lesions appears to be significantly decreased, as compared to intact skin parts in patients with the same degree of peripheral vascular disease (chapter 4). The significant increase in the diameter of capillaries in the rims of ischaemic skin lesions probably compensates for the considerable decrease in the number of capillaries, as far as the surface area for exchange is concerned (chapter 4). This idea is supported by the slightly higher nutritional skin blood flow at rest in these rims, as compared to the nutritional skin blood flow at rest in the intact skin. An increase in nutritional skin blood flow at rest in the rims of ischaemic skin lesions by means of an adjustment at the capillary level, which is probably caused by vasodilating metabolites released from these damaged skin parts, might serve a twofold function: 1) prevention of further enlargement of the ischaemic skin lesion and 2) healing of the ischaemic skin lesion. The increase in capillary diameter in the rims of ischaemic skin lesions is in accordance with the finding of Peeze Binkhorst and colleagues in an animal study, showing an increase in capillary lumen adjacent to degenerated and leukocyte-invaded muscle fibers (11). They speculated that the increase in cross-sectional capillary luminal area represented a dimensional reserve to be utilized for increased capillary blood flow.

Nutritional skin blood flow at rest appears to be maintained in the sitting position. This may be beneficial to patients with severe peripheral vascular disease. Therefore, these patients are advised to assume a sitting position with the legs dependent during the day while intermittently activating their venous calf pump by means of ankle dorsiflexion and plantar flexion to lower venous pressure, to sleep with their feet slightly below heart level (anti-Trendelenburg's position), and not to wear pinching shoes. 


\section{REFERENCES}

1. Fontaine R, Riveaux R, Kim M, Kieny R. Résultats des operawns hyperémiantes (sympathectomies lombaires et artériectomies) dans les oblitérations artérielles chroniques spontanées des membres. Rev Chir 1953;72:204-30.

2. Bone GE, Pomajzl MJ. Toe blood pressure by photoplethysmography: An index of healing in forefoot amputation. Surgery 1981;89:569-74.

3. Eickhoff JH, Ishihara S, Jacobsen E. Effect of arterial and venous pressures on transcutaneous oxygen tension. Scand J Clin Lab Invest 1980;40:755-60.

4. Creutzig A, Dau D, Caspary L, Alexander K. Transcutaneous oxygen pressure measured at two different electrode core temperatures in healthy volunteers and patients with arterial occlusive disease. Int $\mathbf{J}$ Microcirc Clin Exp 1987; 5:373-80.

5. Creutzig A, Caspary L, Alexander K. Disturbances of skin microcirculation in patients with chronic arterial occlusive disease and venous incompetence. Vasa 1988; 17:77-83.

6. Amery A, Bossaert $H$, Deruyttere $M$, Vanderlinden L, Verstraete M. Influence of body posture on leg blood flow. Scand J Clin Lab Invest 1973;31 (suppl 128):29-36.

7. Henriksen $O$. Local reflex in microcirculation in human subcutaneous tissue. Acta Physiol Scand 1976;97:447-56.

8. Creutzig A, Caspary L, Hertel RF, Alexander K. Temperature-dependent laser Doppler fluxmetry in healthy and patients with peripheral arterial occlusive disease. Int J Microcirc Clin Exp 1987;6:381-90.

9. Hassan AAK, Tooke JE. Mechanism of the postural vasoconstrictor response in the human foot. Clin Sci 1988;75:379-87.

10. Jacobs MJHM, Beckers RCY, Jörming PJG, Slaaf DW, Reneman RS. Microcirculatory haemodynamics before and after vascular surgery in severe limb ischaemia - the relation to post-operative oedema formation. Eur J Vasc Surg 1990;4:525-9.

11. Peeze Binkhorst FM, Kuipers H, Heymans J, et al. Exercise-induced focal skeletal muscle fiber degeneration and capillary morphology. J Appl Physiol 1989;66:2857-65. 


\section{CHAPTER 7}

\section{SUMMAR Y}

An inadequate blood supply to the lower limbs (ischaemia), due to peripheral arterial obstructive disease, often leads to pain during exercise (intermittent claudication) or even at rest. At present, only the macrocirculation, responsible for the transport of blood, is routinely investigated in patients suffering from peripheral vascular disease, although the occurrence of ischaemic skin lesions (ulcers and/or necrosis) indicates an impaired nutritional skin microcirculation. The nutritional skin microcirculation represents the level, at which nutrients and waste products are exchanged between blood and tissue.

As described in chapter 1 , this thesis not only discusses the results of macrocirculatory and skin microcirculatory investigations in patients with various degrees of peripheral vascular disease, it also reports on the relation between the macrocirculation and the skin microcirculation and especially on the way, in which the skin microcirculation is able to adapt to changes in macrocirculatory blood supply. In this study, the macrocirculation was investigated with the use of Doppler ultrasound, plethysmography and arteriography. The nutritional part of the skin microcirculation, which consists of capillaries providing the nutrition of the skin, was examined with the use of intravital skin capillary microscopy. Transcutaneous oxygen pressure $\left(\mathrm{tcpO} \mathrm{O}_{2}\right)$ monitoring was applied to be informed of the total skin microcirculation, which comprises the abovementioned nutritional part and a thermoregulatory part, consisting of arteriovenous anastomoses, and arterial and venous plexuses.

In chapter 2, the subjects, who participated in this study, are presented. Thirty-nine patients with intermittent claudication (stage 2 according to Fontaine's classification $=$ moderate peripheral vascular disease), 38 patients suffering from rest pain or ischaemic skin lesions with or without rest pain (stages 3 and 4 according to Fontaine's classification = severe peripheral vascular disease) and 10 healthy control subjects were examined in this study.

Chapter 3 deals with the investigation of the lower limb macrocirculation. Following historical reviews and descriptions of the investigative methods, the results are presented and discussed. The toe systolic blood pressure, determined in the sitting position with the legs dependent, appeared to be the best variable to estimate the 


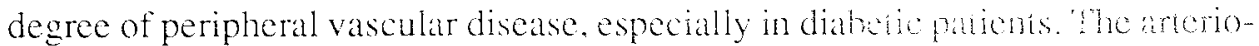
graphic degree of macrocirculatory obstruction did not relate to the haenedynamic data, as obtained with the use of Doppler ultrasound and plethysnography.

Chapter 4 reports on the investigation of the skin microcirculation. Mistorical reviews and descriptions of the techniques of tcp $\mathrm{O}_{2}$ monitoring and intravital skin capillary microscopy precede data presentation and discussion. Total skin blood flow at rest, as reflected by $t c \mathrm{PO}_{2}$ monitoring, was significantly impared in patients with severe peripheral vascular disease. The time needed to reach $50 \%$ of the $t c \mathrm{PO}_{2}$ value at rest following the release of a transient arteriat occlusion appeared to provide the best separation between healthy subjects and patients with moderate peripheral vascular disease. Investigation of the nutritional skin microcirculation with the use of intravital skin capillary microscopy in the sitting position with the legs dependent showed that nutritional skin blood flow at rest in the intact skin of patients with severe peripheral vascular disease did not differ significantly from that of healthy subjects and patients with moderate peripheral vascular disease, despite their severely impaired macrocirculatory blood supply. Unlike in healthy subjects and patients with moderate peripheral vascular disease, however, only a slight increase in red blood cell velocity following the release of a transient arterial occlusion was observed in the intact skin of patients suffering from severe peripheral vascular disease. This indicates that at rest in the sitting position the arterioles in the intact skin of patients with severe peripheral vascular disease are considerably dilated to increase nutritional skin blood flow. Since this dilation is almost at the maximum and no other precapillary compensatory mechanism is available, a (further) decrease in nutritional skin blood flow at rest, for example, due to progression of peripheral vascular disease and/or local external skin compression, is likely to cause the development of ischaemic skin lesions. In the rims of ischaemic skin lesions a significant increase in the diameter of capillaries associated with a considerable decrease in the number of capillaries per surface area was seen. Since in these rims nutritional skin blood flow at rest appeared to be slightly higher, as compared to the nutritional skin blood flow at rest in the intact skin, the increase in diameter must probably be regarded as an ultimate capillary adjustment to increase nutritional skin blood flow at rest.

In chapter 5 , the relation between the macrocirculation and skin microcirculation is discussed. A toe systolic blood pressure, determined in the supine position, higher than $60 \mathrm{~mm} \mathrm{Hg}$ appeared to be indicative of a normal total skin blood flow at rest. Below $60 \mathrm{~mm} \mathrm{Hg}$, however, toe systolic blood pressure values did not predict the level of the total skin blood flow at rest. Toe systolic blood pressure values, determined in the sitting position with the legs dependent, nor the arteriographic degree of macrocirculatory obstruction had any predictive value for the level of the nutritional skin microcirculation, as determined in the sitting position.

In chapter 6, a general discussion about the most striking macrocirculatory and skin microcirculatory findings concludes this thesis. 


\section{CHAPTER 8}

\section{SAMENVATTING}

Wanneer de benen onvoldoende van bloed worden voorzien (ischemie) door vernauwing van de bloed toevoerende vaten (perifeer arterieel obstructief vaatlijden) kan pijn onstaan tijdens het lopen (claudicatio intermittens) en zelfs in rust. In het algemeen worden alleen de grote bloed toevoerende vaten (macrocirculatie) routinematig onderzocht bij patiënten met perifeer arterieel vaatlijden, ofschoon het voorkomen van ischemische huidafwijkingen (ulcera en/of necrose) wijst op een gestoorde nutritieve huidmicrocirculatie. Op het niveau van de nutritieve huidmicrocirculatie vindt namelijk de uitwisseling van voedings- en afvalstoffen plaats.

Zoals beschreven in hoofdstuk 1, worden in dit proefschrift niet alleen de resultaten van het macrocirculatoire en huidmicrocirculatoire onderzoek bij patiënten met in emst verschillend perifeer arterieel vaatlijden besproken, ook de relatie tussen de macrocirculatie en de huidmicrocirculatie en met name de manier waarop de huidmicrocirculatie zich kan aanpassen aan veranderingen in de macrocirculatoire bloedvoorziening komt aan de orde. De macrocirculatie werd onderzocht met behulp van Doppler ultrageluid, plethysmografie en arteriografie. Het nutritieve gedeelte van de huidmicrocirculatie, bestaande uit haarvaten (capillairen) die de huid van voedingsstoffen voorzien, werd bestudeerd met behulp van intravitaal capillairmicroscopie. Informatie over de totale huidmicrocirculatie, die naast het zojuist genoemde nutritieve gedeelte gevormd wordt door een temperatuurregulerend deel, bestaande uit arterioveneuze shunts, en arteriële en veneuze netwerken, werd verkregen door middel van het transcutaan meten van de zuurstofspanning (tcpO 2 meting).

In hoofdstuk 2 worden de verschillende groepen van personen, die onderzocht werden, gepresenteerd. Negenendertig patiënten met claudicatio intermittens (stadium 2 volgens de classificatie van Fontaine = matig ernstig perifeer arterieel vaatlijden), 38 patiënten met rustpijn of ischemische huidaiwijkingen met of zonder rustpijn (stadium 3 en 4 volgens Fontaine's classificatie = ernstig perifeer arterieel vaatlijden) en 10 gezonde, controle-personen participeerden in dit onderzoek. 


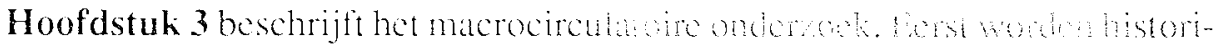

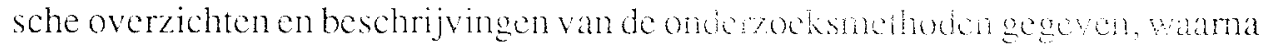
de resultaten worden gepresenteerd en besproken. liet blek. dat de systolische teenbloeddruk, gemeten in zittende houding met athangend been, het beste de emst van perifeer arterieel vaatlijden weerspiegelde en met name bij patiënten met diabetes mellitus. De arteriografisch beoordeelde ennst van de macrocirculatoire obstructie was niet gerelateerd aan hemodynamische gegevens, zoals verkregen met behulp van Doppler ultrageluid en plethysmografie.

In hoofdstuk 4 komt het onderzoek van de huidmicrocirculatie aan de orde. Historische overzichten en beschrijvingen van de gebruikte technieken ( $\operatorname{tcpO} \mathrm{O}_{2}$ meting en intravitaal capillairmicroscopie) gaan vooraf aan de presentatie en bespreking van de data. De totale bloeddoorstroming van de huid in rust bleek beduidend lager te zijn bij patiënten met ernstig perifeer arterieel vaatlijden. De tijd, die nodig was om weer de helft van de oorspronkelijke tcpO $\mathrm{O}_{2}$ waarde in rust te bereiken na het opheffen van een tijdelijke volledige arteriële afsluiting, bleek het beste onderscheid te maken tussen gezonde controle-personen en patiënten met matig emstig perifeer arterieel vaatlijden. Onderzoek van het nutritieve gedeelte van de huidmicrocirculatie in zittende houding met afhangend been toonde geen verschil aan tussen de doorbloeding van de intacte huid van gezonde controle-personen, patiënten met matig emstig en patiënten met emstig perifeer arterieel vaatlijden. De slechts geringe toename van de snelheid van de rode bloedlichampjes (erythrocyten) in de intacte huid na het opheffen van cen tijdelijke, volledige arteriële afsluiting bij patiënten met ernstig perifeer arterieel vaatlijden wijst erop, dat de arteriolen (voorlopers van de capillairen, precapillaire bloedvaten) in rust reeds vrijwel volledig verwijd zijn en dat in rust de huidmicrocirculatie, althans op precapillair niveau, bijna al z'n reserves heeft aangesproken. Het is zeer waarschijnlijk, dat bij afwezigheid van een ander precapillair aanpassingsmechanisme (verdere) afname van de nutritieve huiddoorbloeding, bijvoorbeeld door verergering van het vaatlijden of door locale druk van buitenaf, het ontstaan van ischemische huidafwijkingen veroorzaakt. In de rand van zulke ischemische huidafwijkingen werd enerzijds een afname van het aantal capillairen per oppervlak gezien, anderzijds een toename van de diameter van de nog resterende capillairen. Verder bleek in rust de nutritieve bloeddoorstroming in deze randen iets hoger te zijn in vergelijking met de intacte huid. Dit fenomeen wijst erop, dat een toename van de capillaire diameter hoogstwaarschijnlijk een laatste mogelijkheid is om de nutritieve huiddoorstroming te verbeteren.

In hoofdstuk 5 wordt de relatie besproken tussen de macrocirculatie en de huidmicrocirculatie. Een systolische teenbloeddruk, gemeten in liggende houding, hoger dan $60 \mathrm{~mm} \mathrm{Hg}$, ging gepaard met een normale totale huiddoorbloeding. Echter systolische teenbloeddrukken lager dan $60 \mathrm{~mm} \mathrm{Hg}$ waren niet voorspellend voor wat de totale huiddoorstroming betrof. De nutritieve huiddoor- 
stroming bleek niet te zijn gerelateerd aan de systolische teenbloeddruk, gemeten in zittende houding met afhangend been, noch aan de arteriografisch beoordeelde ernst van de macrocirculatoire obstructie.

In het afsluitende hoofdstuk 6 wordt ingegaan op de meest opvallende bevindingen. 



\section{PUBLICATIONS}

\section{PAPERS}

- Beckers RCY, Jörning PJG, Slaaf DW, Reneman RS, Jacobs MJHM. Effect of ketanserin on macrocirculatory and microcirculatory blood flow in patients with intermittent claudication. A prospective randomized study. Eur J Clin Pharmacol 1989;37:295-6.

- Jacobs MJHM, Beckers RCY, Jöning PJG, Slaaf DW, Reneman RS. Microcirculatory hacmodynamics before and after vascular surgery in severe limb ischaemia - the relation to post-operative oedema formation. Eur J Vasc Surg 1990;4:525-9.

- Jacobs MJHM, Jörning PJG, Beckers RCY, Ubbink DT, van Kleef M, Slaaf DW, Reneman RS. Foot salvage and improvement of microvascular blood flow as a result of epidural spinal cord electrical stimulation. J Vasc Surg 1990; 12:354-360.

\section{ABSTRACTS}

- Beckers RCY, Jörning PJG, Slaaf DW, Reneman RS, Jacobs MJHM. Macrocirculatory and microcirculatory evaluation of ketanserin treatment in patients with intermittent claudication. Acta Chir Scand 1988; suppl 548:7.

- Beckers RCY, Jacobs MJHM, Jörning PJG, Kooman JP, Slaaf DW, Reneman RS. Microcirculatory investigation can distinguish between patients with intermittent claudication and healthy persons. Int J Microcirc Clin Exp 1988; special issue:S37.

- Jacobs MJHM, Beckers RCY, Jörning PJG, Slaaf DW, Reneman RS. Macroand microcirculatory studies in severe limb ischemia before and after vascular surgery. Int J Microcirc Clin Exp 1988; special issue:S62.

- Kooman JP, Jacobs MJHM, Beckers RCY, Jörning PJG, Slaaf DW, Reneman $\mathrm{RS}$. The influence of hydrostatic pressure on transcutaneous $\mathrm{pO}_{2}$. Int J Microcirc Clin Exp 1988; special issue:S138.

- Beckers RCY, Jacobs MJHM, Slaaf DW, Reneman RS. Morphological and haemodynamic study of nutritional skin microcirculation in patients with lower limb ischaemia. Int J Microcirc Clin Exp 1990;9(suppl 1):121. 
- Jacobs MJHM, Beckers RCY, Ubbink DT, Slaaf DW, Reneman RS. Improved blood flow and foot salvage in patients with severe limb ischemia following spinal cord stimulation. Int J Microcirc Clin Exp 1990;9(suppl 1):27.

- Jacobs MJHM, Ubbink DT, Beckers RCY, Slaaf DW, Reneman RS. Capillary haemodynamics in patients with peripheral vascular disease. Int J Microcirc Clin Exp 1990;9(suppl 1):142. 


\section{DANKWOORD}

Dit proefschrift zou onvolledig zijn als niet zou worden stilgestaan bij diegenen, die bij het tot stand komen ervan hebben geholpen. Graag wil ik hen dan ook bij deze van harte bedanken.

Prof.Dr. G. Kootstra. Beste Gauke, jij bood mij de gelegenheid om binnen de afdeling Chirurgie van het Academisch Ziekenhuis Maastricht het in dit proefschrift beschreven onderzoek te verrichten.

Prof.Dr. R.S Reneman. Beste Rob, ondanks het feit, dat je het altijd zeer druk had, kon ik steeds weer opnieuw een beroep doen op jouw wetenschappelijk inzicht.

Dr. M.J.H.M. Jacobs. Beste Michael, door jouw pionierswerk heeft het klinisch, non-invasieve, microcirculatoire onderzoek binnen het Academisch Ziekenhuis Maastricht en met name binnen de afdeling Chirurgie gestalte gekregen. Daardoor werd ik in staat gesteld het hier beschreven onderzoek te verrichten. Jouw gedrevenheid, kennis en adviezen waren voor mij zeer waardevol. Ook in het jaar, dat je voor een vaatchirurgische stage verbleef in de Verenigde Staten, kon ik op je rekenen.

Dr. P.J.G. Jörning. Beste Paul, ik leerde je kennen toen ik als student onder jouw begeleiding keuze-onderwijs volgde. Jouw klinisch inzicht en consciëntieuze manier van werken spraken mij erg aan. Tijdens mijn onderzoek heb ik dat nóg sterker ervaren. Jouw macrocirculatoire, vaatchirurgische kennis en interesse in de microcirculatie waren voor mij van groot belang. Zelfs toen je tot mijn grote spijt Maastricht verliet en ging werken in het Sophia Ziekenhuis te Zwolle, zorgde je ervoor dat 'de kar op de rails bleef'. Bij deze wil ik ook Loes Jörning bedanken voor haar gastvrijheid.

Dr. D.W. Slaaf. Beste Dick, vaak heb ik je lastig gevallen met het herlezen van stukken tekst. Toch deed je het steeds weer kritisch en snel. Jouw (bio)physische kennis en mathematisch inzicht waren onmisbaar voor de interpretatie van de verkregen resultaten.

Renée Dresens-Penders, Edith Ermers en Yvonne Reijnders. Zonder jullie hulp zou dit proefschrift nooit geschreven kunnen zijn. Terwijl Yvonne zorgde voor een perfekte organisatie binnen het vaatlaboratorium, stonden Renée en Edith met hun kennis en vaardigheid garant voor gedegen macrocirculatoir onderzoek. Zeer stimulerend voor mij was de leuke sfeer, waarin ik al die tijd met jullie heb 
kunnen samenwerken. Met recht kon er gesproken worden van een "upervaatlab".

Ing. M.A. Alewijnse. Beste Rinus, gelukkig was je steeds bereid me te helpen wanneer de kwiklamp van de capillaimicroscoop het op cruciale momenten liet afweten.

Drs. J.W. Veldhuizen en Drs. M.A.M. Vromen, kamergenoten van het eerste uur. Beste Jan, jouw vaak humoristische, relativerende opmerkingen zette mij aan het denken... Beste Marion, jij gaf een extra dimensie aan de goede sfeer op onze kamer. Ook zorgde je ervoor door 'voortdurend' de telefoon bezet te houden, dat Jan en ik 'ongestoord' konden werken...

Drs. S.H.A. Schmeets. Beste Sep, onvergetelijk voor mij zijn de talloze avonden, die we samen doorgebracht hebben in de Perroen. Doordat het onderzoek die avonden geheel niet ter sprake kwam, kon ik er de volgende ochtend weer met nieuwe energie mee doorgaan...

Drs. J.N. Bouwes Bavinck. Beste Jan Nico, jij leerde mij werken met de Apple Macintosh.

De afdeling Dermatologie van het Academisch Ziekenhuis Leiden (hoofd: Prof.Dr. B.J. Vermeer) bood mij, als nieuwe werkgever, ruim de gelegenheid mijn proefschrift af te ronden.

Lieve Marion, er waren momenten dat ik onvoldoende aandacht aan je kon schenken. Met dit proefschrift is het onderzoek nú afgerond!!!

Tenslotte dank ik de leden van de beoordelingscommissie voor het kritisch doorlezen van het manuscript. 


\section{CURRICULUM VITAE}

Roeland C.Y. Beckers werd geboren op 11 februari 1959 te Maastricht. In 1978 behaalde hij het diploma Gymnasium 3 aan het Henric van Veldeke College te Maastricht. Hij studeerde Duitse Taal- en Letterkunde aan de Katholieke Universiteit Nijmegen in de periode 1978-1979. Vanaf november 1979 tot september 1980 was hij leerling radiologisch laborant in het St.Gregorius de Grote Ziekenhuis te Brunssum. In 1980 begon hij met de studie Genecskunde aan de Rijksuniversiteit Limburg te Maastricht, waar in 1986 het artsdiploma behaald werd. Vanaf oktober 1986 tot november 1989 verrichtte hij als research-assistent bij de afdeling Chirurgie van het Academisch Ziekenhuis Maastricht (hoofd: Prof.dr. G. Kootstra) het in dit proefschrift beschreven onderzoek. In 1990 werkte hij gedurende een aantal maanden als arts-assistent Chirurgie in het St. Jozefzickenhuis te Kerkrade. Vanaf februari 1991 is hij werkzaam als arts-assistent Dermatologie in het Academisch Ziekenhuis Leiden (hoofd: Prof.Dr. B.J. Vermeer), waar hij sinds 1 oktober 1991 in opleiding is tot dermatoloog. 